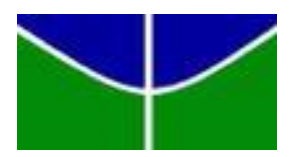

UNIVERSIDADE DE BRASÍLIA

PROGRAMA DE PÓS-GRADUAÇÃO EM ECONOMIA

DOUTORADO EM ECONOMIA

FERNANDA LEDO MARCINIUK

\title{
A Influência de Fatores Políticos e Institucionais na Política Fiscal Subnacional
}

BRASÍLIA 


\section{A Influência de Fatores Políticos e Institucionais na Política Fiscal Subnacional}

Tese apresentada ao Programa de PósGraduação em Economia da Faculdade de Economia, Administração e Contabilidade da Universidade de Brasília como requisito parcial para obtenção do título de Doutora em Economia. Área de concentração: Setor Público.

Orientador: Prof. Dr. Maurício Soares Bugarin

BRASÍLIA 
Marciniuk, Fernanda Ledo.

A Influência de Fatores Políticos e Institucionais na Política Fiscal / Fernanda Ledo Marciniuk. - 2016.

$87 \mathrm{f.:} 31 \mathrm{~cm}$

Tese (Doutorado) - Universidade de Brasília, Faculdade de Economia, Administração e Contabilidade, Programa de Pós-Graduação em Economia, 2016.

1. Política Fiscal Subnacional. 2. Reeleição. 3. Transferências Voluntárias. 4. Convênios. 5. Federalismo. I. Bugarin, Maurício Soares. II. Universidade de Brasília. III. Título. 


\section{A Influência de Fatores Políticos e Institucionais na Política Fiscal Subnacional}

A Comissão Examinadora, abaixo identificada, aprova a Tese apresentada ao Programa de PósGraduação em Economia da Faculdade de Economia, Administração e Contabilidade (FACE) da Universidade de Brasília como requisito parcial para obtenção do título de Doutora em Economia. Área de concentração: Setor Público.

Prof. Dr. Maurício Soares Bugarin - Orientador

Departamento de Economia - FACE/UnB

Prof. Dr. - Rafael Terra

Departamento de Economia - FACE/UnB

Prof. $^{\text {a }}$ Dr. ${ }^{\text {a }}$ - Maria Tanuri Pianto

Departamento de Economia - FACE/UnB

Prof. Dr. - Mathieu Turgeon

Departamento de Ciência Política - IPOL/UnB

Prof. Dr.- Sérgio Gadelha

Secretaria do Tesouro Nacional - STN

Brasília, 6 de julho de 2016. 


\section{LISTA DE FIGURAS}

Figura 1.1 - Distribuição espacial da proporção entre receitas próprias e a receita corrente líquida 29

Figura 1.2 - Diagrama dos grupos de prefeitos. 30

Figura 1.3 - Estratégia de identificação dos grupos de tratamento e controle 43

Figura 2.1 - Área de influência política do PT de acordo com o indicador Quociente Locacional - 2006/2010.

Figura 2.2 - Área de influência política do PSDB de acordo com o indicador Quociente Locacional - 2006/2010

Figura 2.3 - Área de influência política do PMDB de acordo com o indicador

Quociente Locacional - 2006/2010

Figura 2.4 - Área de influência política do PP de acordo com o indicador Quociente Locacional - 2006/2010 70

Figura 2.5 - Índice de Taagepera para eleições legislativas - 2006/2010 71

\section{LISTA DE GRÁFICOS}

Gráfico 1.1 - Resultados primários do governo federal (em proporção do PIB) 1997-2005

Gráfico 1.2 - Análise gráfica do resultado primário municipal pelo Produto Interno Bruto (PIB) nacional - 2001-2012 .

Gráfico 1.3 - Análise gráfica da despesa com pessoal e receita corrente líquida .. 27

Gráfico 1.4 - Divisão das receitas públicas municipais em proporção da receita corrente líquida....

Gráfico 2.1 - Montante de Convênios Firmados e Convênios Executados (reais) $-1997-2012$

\section{LISTA DE QUADROS}

Quadro 1.1 - Variáveis dependentes utilizadas nos testes empíricos 34

Quadro 2.1 - Descrição das variáveis dependentes 74 


\section{LISTA DE TABELAS}

Tabela 1.1 - Resultados do modelo desenvolvido por Meneguin e Bugarin

Tabela 1.2 - Porcentagem de municípios e porcentagem da média de gastos divididas em três grupos com referência aos limites de gastos de pessoal - 20012012

Tabela 1.3 - Descrição, estatísticas descritivas e efeito esperado das variáveis de interesse e de controle.

Tabela 1.4 - Coeficientes obtidos para o modelo 1 de painel com efeitos fixos.... 38

Tabela 1.5 - Resultados do modelo de efeitos fixos robustos

Tabela 1.6 - Diferença de média entre as variáveis de controle dos grupos de tratados e de controle antes do tratamento

Tabela 1.7 - Resultados da metodologia de diferenças em diferenças entre quantis

Tabela A.1 - Resumo das variáveis de controle referente às características institucionais orçamentárias

Tabela A.2 - Resultados para os testes de dados em painel com efeitos fixos ..... 50

Tabela A.3 - Testes para definição entre efeitos fixos e efeitos aleatórios .

Tabela A.4 - Teste de multicolinearidade e teste para autocorrelação de todas as equações.

Tabela A.5 - Teste da hipótese nula de que os coeficientes entre diferentes quantis são iguais

Tabela 2.1 - Características dos convênios firmados por setor - 2001-2012.

Tabela 2.2 - Indicador Quociente Locacional para o Poder Legislativo federal 2006-20110

Tabela 2.3 - Descrição das variáveis de controle e suas estatísticas descritivas....

Tabela 2.4 - Resultados das estimações para dados em painel de efeito fixo para o modelo 1

Tabela B.1 - Resultado dos testes de Chow e teste de Hausman 80

Tabela B.2 - Resultado dos testes de autocorrelação e de heterocedasticidade em grupo 


\section{AGRADECIMENTOS}

O curso de doutorado foi sem dúvida um dos maiores desafios da minha vida e esta tese é o resultado da ajuda dedica e do apoio de diversos pessoas. Mesmo não havendo espaço para agradecer a todos que contribuíram para este trabalho, alguns agradecimentos especiais gostaria de fazer nominalmente.

Aos meus pais, Melécio e Zelite, por todo o apoio incondicional, força e amor durante toda a minha vida. Sem essa força eu certamente não teria finalizado e realizado mais esse sonho. Aos meus irmãos, Letícia, Geovana e Juninho pelo carinho e companheirismo.

Ao professor Maurício Bugarin pela dedicação e principalmente pela paciência que teve comigo. Soube respeitar meu tempo e os vários momentos difíceis que passei durante a construção do trabalho. Agradeço em especial a oportunidade de trabalhar com alguém tão sério e dedicado à pesquisa.

Aos membros da banca pelas valiosas críticas e sugestões ao trabalho. Com certeza todas foram muito importantes para a melhoria desse trabalho.

Não poderia deixar de agradecer a Gustavo Machado, que apesar de nossos caminhos terem se desencontrado, foi, sem dúvidas, muito importante para que eu conseguisse conquistar esse sonho.

Quero agradecer a todos os amigos da UNB que me acompanharam durante essa jornada. Agradeço em especial Liliane pelo apoio na correção do texto, pelas críticas totalmente construtivas e também pelas conversas profundas e motivadoras. Aos amigos Mário Rubem, Oliveira Alves Pereira Filho e Daniel Reiss pelos momentos divertidos de discussão no cafezinho e principalmente pelo apoio e ajuda na construção do trabalho. Ao professor Rodrigo Peñaloza por todo o apoio dado na construção do meu projeto inicial para pleitear a vaga no doutorado.

Deixo aqui meus sinceros agradecimentos aos amigos Alice Vogado, Rodrigo Mendes, Luiz Medeiros, Taize Carvalho, Vanessa Carvalho e André Serrano por todo apoio emocional, pelos chopes, pelas risadas e por fazerem dessa fase muito mais leve. Não posso deixar de agradecer ao grande apoio do casal Indira e Rodrigo Otto - sem dúvidas vocês fizeram toda a diferença na minha vida e agradeço imensamente a confiança, o apoio, os puxões de orelha e os almoços super "lights" do chefe Otto.

Agradeço à Capes pelo apoio financeiro. A todos os professores e funcionários da UNB, em particular Joana e Carina por estarem sempre dispostos a ajudar nos problemas burocráticos. 


\section{RESUMO}

A análise da relação entre a gestão fiscal e a dinâmica do sistema político se apresenta como um fértil objeto de estudo, principalmente depois do processo de descentralização fiscal pós Constituição de 1988, no qual os municípios passaram a desempenhar um papel de destaque no cenário nacional. Esta tese é dividida em uma introdução geral e dois ensaios. O primeiro ensaio investigou se os incentivos eleitorais, aqui traduzidos no instituto da reeleição, influenciam os prefeitos candidatos a aumentar o desempenho na política fiscal do município. Os resultados empíricos apontam para um melhor desempenho na condução das contas públicas por prefeitos de primeiro mandato e que possuem perspectivas de concorrer ao segundo mandato em detrimento aos prefeitos de primeiro mandato que não possuem essa perspectiva e aos prefeitos de segundo mandato. O segundo ensaio evidencia a existência de uma distribuição mais favorável das transferências, via convênios federais, para municípios cujo partido do prefeito possui identidade partidária com os partidos que possuem influência política na região em que se localiza o município. Os resultados encontrados são particularmente interessantes nesse momento em que o Brasil passa por uma crise de ordem política e de credibilidade no governo, bastante evidenciados pelos vários escândalos de corrupção envolvendo barganhas políticas utilizando transferências voluntárias, em especial as emendas parlamentares. Em geral, este trabalho contribui com evidências empíricas de que fatores de ordem política e institucional possuem influência na condução da política fiscal dos entes subnacionais no Brasil.

Palavras-chave: Política Fiscal Subnacional. Reeleição. Transferências Voluntárias. Convênios. Federalismo. 


\begin{abstract}
The way fiscal management relates to the political system dynamics and institutions is a promising study object in Brazil, especially after the 1988 Constitution, which implemented a large fiscal decentralization, with municipalities being moved to the foreground in the national scene. This dissertation provides a few contributions in the debate. The first essay investigates if electoral incentives, represented here by the re-election, make the incumbent mayor-nominee to enhance its township fiscal performance. The empirical results suggest a better budgetary performance for first-term mayors that intend to run for a second term, as compared to firstterm mayors that do not target a second term, and second-term mayors. In fact the analysis shows that first-term mayors without the intention of a second term tend to act just like secondterm mayors. The second essay highlights the existence of a bias in the distribution of federal transfers, benefiting townships in which the mayor's party has party affinity with the influential political coalition in the region where the township is located. The results are particularly interesting, considering Brazil's current political crisis in which government credibility is hampered by the several corruption scandals, most of them involving political bargains that use voluntary transfers, particularly the ones from congressional amendments. In summary, this work provides empirical evidence highlighting the political and institutional variables that affect fiscal policy at the sub-national levels in Brazil.
\end{abstract}

Keywords: sub-national fiscal policy, re-election, voluntary transfers, accords, federalism. 


\section{SUMÁRIO}

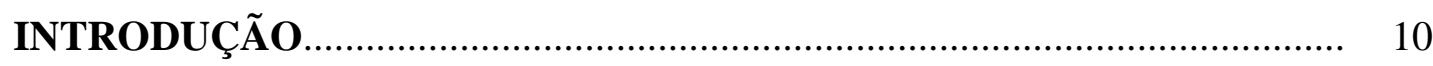

Ensaio 1 - A influência da reeleição nas políticas fiscais subnacionais............ 14

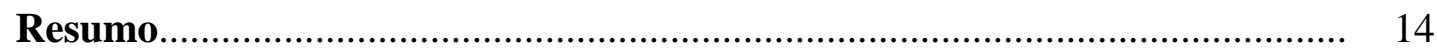

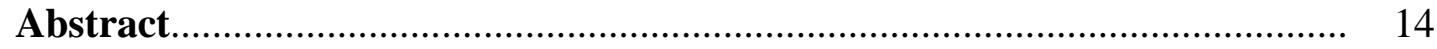

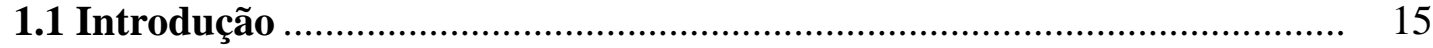

$1.2 \mathrm{O}$ modelo de controle eleitoral ................................................................. 17

1.2.1 O modelo de déficit fiscal e reeleição por Meneguin e Bugarin............. 20

1.3 Panorama da política fiscal subnacional ................................................ 22

1.4 Análise econométrica: o efeito da reeleição sobre o comportamento

fiscal nos municípios ........................................................................... 29

1.4.1 Variáveis dependentes...................................................................... 31

1.4.2 Variáveis de controle .......................................................................... 32

1.4.2.1 Outras variáveis políticas ..................................................................... 32

1.4.2.2 Características dos candidatos............................................................. 34

1.4.2.3 Aspectos socioeconômicos .................................................................... $\quad 35$

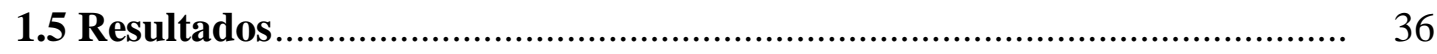

1.5.1 Resultados da metodologia tradicional de dados em painel...................... 37

1.5.2 Resultados do método das diferenças e diferenças entre quantis com

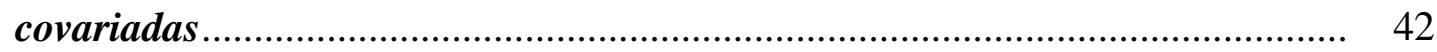

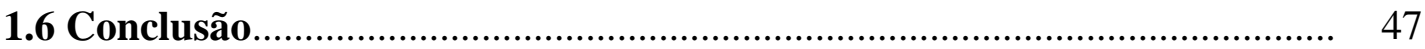

ANEXO A - Anexos do Ensaio 1....................................................... 49

A.1 Resultado de dados em painel para o modelo contendo variáveis de controle orçamentárias ............................................................................. 49

A.2 Testes para o modelo de dados em painel .............................................. 53

A.3 Testes para a metodologia de diferenças em diferenças ........................... 53

Ensaio 2 - Análise da presença de motivação partidária nas transferências voluntárias da União..................................................................................... 55

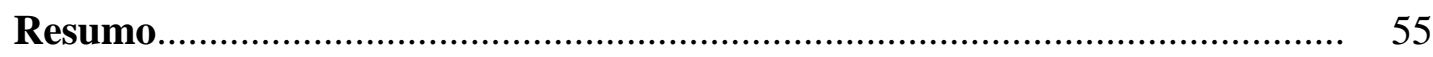

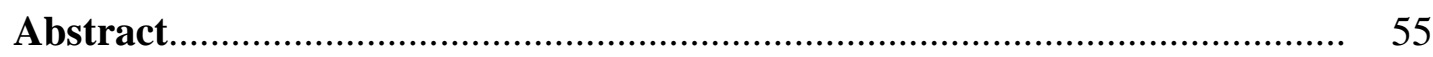

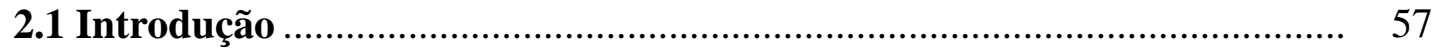

2.2 Panorama das transferências voluntárias - convênios ............................ 60 
2.3 A influência das transferências voluntárias no funcionamento do sistema político brasileiro.

2.4 Concentração dos votos por partido no Poder Legislativo federal

2.4.1 Medidas de concentração para os municípios brasileiros para as

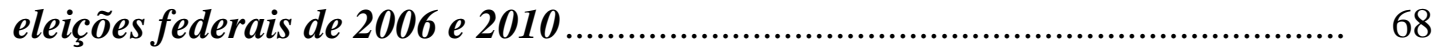

2.5 Análise econométrica ........................................................................ 71

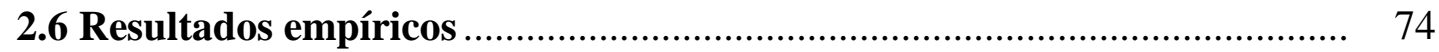

2.7 Conclusão

ANEXO B - Anexos do Ensaio 2 ….................................................... 80

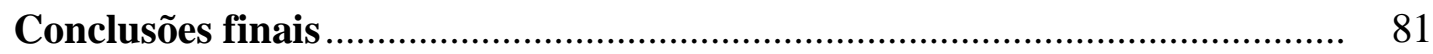

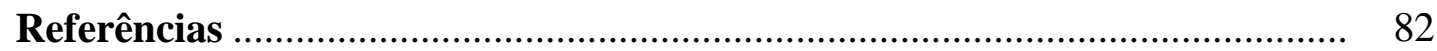




\section{INTRODUÇÃO}

Ao longo dos últimos 35 anos, as democracias ocidentais vivenciaram um crescimento da instabilidade política, intensamente marcada por mudanças frequentes dos partidos políticos no poder, seus programas e suas filosofias, impulsionadas, pelo menos em parte, por dificuldades econômicas (SPENCE \& BRADY, 2016). Em uma pesquisa recente, David Brady (BRADY, 2016) aborda a correlação entre a crescente instabilidade política e o declínio do desempenho econômico, salientando que nos países com desempenho econômico abaixo da média mundial há uma volatilidade eleitoral mais elevada. Desse modo, o ambiente político pode ser considerado bastante importante dentro do cenário de deterioração das contas públicas.

O relatório “World Economic Outlook” (WEO, 2016), resultado de pesquisas feitas pelo Fundo Monetário Internacional, afirma que os principais riscos para a economia brasileira estão ligados à instabilidade do cenário político. Essa instabilidade política afetou a capacidade de o governo promover reformas econômicas essenciais ao controle das contas fiscais e, como consequência, tal movimento pode atrasar a recuperação econômica do país. O relatório destaca, em particular, as dificuldades de aprovação no Congresso Nacional de medidas de ajuste e a tomada de decisões políticas econômicas inconsistentes, as quais se refletem na deterioração das contas fiscais.

Nesse contexto de instabilidade política, em 2016, a perda do apoio político e social facilitou a deflagração do processo de impeachment da presidente da República Dilma Roussef. O pedido de afastamento teve por base o uso de manobras contábeis com o objetivo de mascarar déficits no orçamento. Esse pedido foi aprovado pelo plenário da Câmara dos Deputados por 367 votos a favor e 137 contrários, e encaminhado ao Senado Federal o qual tornou a presidente ré com 59 votos a favor e 21 contrários. O julgamento no plenário do Senado, conduzido pelo presidente do Supremo Tribunal Federal Ricardo Lewandowski, considerou Dilma Roussef culpada por 61 dos 81 senadores e foi afastada definitivamente do cargo.

A ideia de que fatores políticos exercem influência sobre as estratégias econômicas dos gestores públicos é raramente contestada e, atualmente, ocupa um lugar de destaque na literatura de Economia Política. A linha ligada à Economia Política positiva entende o déficit público e o acúmulo de dívidas dos entes governamentais como o resultado da interação entre os formuladores de políticas públicas (naturalmente com preferências distintas) e a forma como esta interação ocorre, isto é, argumenta-se que tais resultados fiscais dependem das características político-institucionais da economia a que pertencem. Vários fatores afetam os resultados das políticas fiscais, dentre eles, o sistema eleitoral adotado no país, a organização 
do Estado e, em particular, o modo como os recursos são alocados entre os responsáveis pelas decisões de gastos (ALESINA \& TABELINNI, 1987).

O desenvolvimento desses modelos ligados à Economia Política positiva tem por base a necessidade de imposição de restrições institucionais com o intuito de neutralizar um suposto viés gastador dos governantes. Além disso, enquanto a teoria neoclássica normativa admite um papel de estabilizador automático do déficit durante a busca do equilíbrio nas fases recessivas do ciclo econômico, a Economia Política positiva busca o equilíbrio orçamentário em todos os anos, e não apenas no médio e longo prazos (GOBETTI, 2010).

A influência dos sistemas eleitorais na determinação do déficit público pode ser notada, em especial, na forma como estes afetam a representação dos partidos políticos e na representação de grupos de pressão organizados que compõem a população, por exemplo, os sindicatos e as associações. Essa influência se traduz em diferentes incentivos políticos e, consequentemente, em diferentes formas de se gerir o orçamento público (GIUBERT, 2005).

O sistema político brasileiro é caracterizado por muitos partidos distintos e destituídos de uma ideologia clara. A frequente formação de alianças transitórias e as rivalidades partidárias exercem uma influência bastante forte nos resultados fiscais do governo. Um aspecto essencial ao se analisar as variáveis fiscais é o papel exercido pelo Legislativo no processo orçamentário. A presença de um grande número de partidos evidencia a necessidade de o governo buscar o apoio parlamentar por meio de coalizões. Em regra, a negociação para a formação da base aliada envolve a distribuição de cargos e benefícios de modo a atender os diversos grupos de interesse. Dessa forma, uma maior fragmentação partidária tende a aumentar as chances de ocorrência de um déficit fiscal, pois cada partido representa interesses distintos e, na maioria das vezes, conflitantes (ROUBINI \& SACHS, 1989; COSSIO, 2001). Dessa forma, um governo que possua o apoio da maioria no Legislativo consegue dinamizar a atividade econômica graças à reduzida necessidade de negociações políticas (BIDERMAN \& AVARTE, 2004; AVARTE, 2005).

Outro fator político que pode influenciar as políticas fiscais adotadas é o alinhamento partidário entre os diferentes níveis de governo. Cossio (2001) encontra evidências empíricas de que a identidade partidária entre os chefes do governo federal e estadual reflete uma postura fiscal contracionista, expressada em um menor nível de gasto primário estadual. Menezes (2005) argumenta que governos subnacionais alinhados politicamente ao governo federal tendem a ser mais comprometidos com a política fiscal municipal, apresentam uma maior preocupação com o equilíbrio orçamentário - apresentam um aumento no superávit - e com os gastos essenciais com investimentos, com o social e com infraestrutura. Já no que confere às 
receitas, vários trabalhos analisam a correlação entre o alinhamento partidário dos chefes do executivo e as receitas recebidas pelos municípios brasileiros, mais especificamente das transferências voluntárias. Esses estudos encontram evidências de que alinhamentos partidários entre chefes do executivo de diferentes níveis tendem a facilitar a cooperação em torno das políticas públicas e elevar o volume das transferências de renda intergovernamentais (FERREIRA \& BUGARIN, 2005; 2007; BUGARIN \& MARCINIUK, 2015).

Um aspecto importante e bastante discutido na literatura é a correlação entre resultados fiscais e a possibilidade de reeleição nos diferentes níveis de governo. Os modelos de ciclos políticos assumem que os governantes são motivados pela busca da sua reeleição e, para isso, manipulam as políticas públicas com a intenção de sinalizar competência. Nesta linha de pesquisa, Nordhaus (1975) analisa o trade-off entre inflação e desemprego explorado pelo governante com o objetivo de obter um melhor resultado nas urnas. A utilização de instrumentos de política fiscal para sinalizar competência do governante visando à reeleição foi primeiramente apresentada por Rogoff e Silbert (1988) e Rogoff (1990). Esses autores discutem que os governantes sinalizam competência por meio de cortes de impostos e por meio de aumentos do gasto público em itens perceptíveis aos eleitores (consumo e serviço) e diminuição do gasto com investimento - gastos estes que exigem mais tempo para serem percebidos pelo eleitorado.

Esse trabalho pretende contribuir para o debate recente sobre a influência de fatores políticos e, em segundo plano, sobre os fatores institucionais na política fiscal dos municípios brasileiros, em particular no que se refere à reeleição do chefe do executivo e à identidade partidária entre diferentes níveis de governo. Embora os resultados fiscais do governo federal sejam considerados mais significativos para a avaliação das contas públicas do país, inclusive no cenário internacional, não se pode negligenciar os resultados orçamentários advindos das demais esferas administrativas, o que justifica uma investigação mais detalhada destas. Por isso, pretende-se testar as seguintes afirmações:

i) Governantes aptos a serem reeleitos são mais responsáveis com a gestão das finanças públicas.

ii) Identidade partidária entre prefeitos e governantes dos outros níveis de governo facilita o recebimento de recursos discricionários (em forma de convênios).

Essas análises vêm complementar vários estudos na área de economia política que discutem os fatores condicionantes que influenciam os resultados das políticas fiscais dos entes públicos. 
O primeiro ensaio leva em consideração os possíveis efeitos benéficos da reeleição como um mecanismo controlador dos gastos governamentais. Em suma, esse capítulo pretende contribuir para a discussão da reeleição como um agente disciplinador das ações dos governantes e apresenta evidência de que o monitoramento do eleitorado sobre o desempenho dos prefeitos cria incentivos para o exercício de uma maior responsabilidade fiscal nos municípios.

O segundo ensaio aborda a influência político-partidária presente nas transferências de renda via convênios públicos e contratos de repasse da União. O capítulo traz análises espaciais sobre as áreas de influências políticas dos partidos políticos. Essas influências são medidas por meio das quantidades de votos recebidos pelos candidatos a uma cadeira na Câmara dos Deputados. Neste contexto, este trabalho pretende contribuir com a compreensão dos mecanismos utilizados pelos políticos dos níveis federais de governo, tanto do Poder Executivo quanto do Poder Legislativo, para influenciar as políticas municipais com o objetivo claro de permanência no poder.

Em suma, esta tese pretende contribuir para a compreensão dos fatores políticos e institucionais (em segundo plano) que influenciam as políticas públicas dos entes locais no Brasil. 


\title{
Ensaio 1 - A influência da reeleição nas políticas fiscais subnacionais
}

\begin{abstract}
Resumo
Este artigo analisa empiricamente o efeito potencial do fim da reeleição para o Poder Executivo local sobre as finanças públicas municipais no Brasil. Esse estudo econométrico baseado em dados em painéis dos municípios brasileiros, entre 2001 e 2012, indica que prefeitos em primeiro mandato e que concorreram à reeleição apresentaram comportamento fiscal mais responsável que prefeitos em segundo mandato ou prefeitos em primeiro mandato, mas que não concorreram à reeleição. $\mathrm{O}$ resultado encontrado confirma a literatura teórica existente, que sugere que a reeleição funciona como um instrumento de controle dos eleitores sobre o comportamento fiscal dos políticos eleitos para cargos do Executivo, bem como chama a atenção para o risco de maior deterioração das finanças públicas subnacionais caso a reeleição seja proibida no país.
\end{abstract}

Palavras-chave: Reeleição. Controle Eleitoral. Política Fiscal Subnacional. Resultado Primário. Dados em Painel.

\begin{abstract}
This paper does an empirical investigation on the potential effect of the end of the executive branch's reelection on townships public finances. An econometric procedure based on a panel of Brazilian cities from the year 2001 up to 2012 shows that first-term mayors that compete for reelection are more responsible with the city budget when compared to second-term mayors or first-term mayors that don't compete for reelection. This result confirms the existing theoretical work, which suggests that reelection works as an instrument of voters to control the budgetary behavior of elected officials at the executive branch. Moreover, it highlights the risk of excessive subnational budgetary deficits in case reelection is forbidden.
\end{abstract}

Keywords: reelection, electoral control, subnational fiscal policy, primary result, panel data. 


\subsection{Introdução}

Atualmente a reforma política é um dos assuntos mais recorrentes e debatidos no Brasil. As discussões sobre o tema abrangem várias propostas que visam, em geral, alterar as regras de funcionamento dos partidos políticos, das eleições e do Congresso Nacional a partir do entendimento de que o sistema político vigente prejudica a governabilidade e estimula a corrupção e o agigantamento do Estado.

No epicentro deste debate, encontra-se o instituto da reeleição para chefes do Poder Executivo. Para seus críticos, a alternância de poder e a limitação temporal são apontadas como garantia contra os poderes excepcionais do titular. Ademais, os opositores da reeleição alegam que essa fere o princípio de igualdade nas condições de competição política. O principal argumento, conhecido na literatura como "incumbency effect" ou "efeito titular", é que o candidato titular (aquele que já ocupa cargo de prefeito e se candidata à reeleição) disputa as eleições em condições mais favoráveis do que seus concorrentes pois, além de possuir maior visibilidade política, tem a estrutura administrativa - em particular os recursos públicos - à sua disposição. Dessa forma, os chefes do Poder Executivo podem se aproveitar desses privilégios com ações que visam a sua autopromoção, tais como a propagação de notícias favoráveis ao seu governo em veículos públicos de informação, a participação em eventos, o aumento do quadro de funcionários diretamente ligados a si. Neste contexto, a reeleição geraria um aumento irresponsável nos gastos em municípios com prefeitos com intenção de se candidatar à próxima eleição (BRAMBOR \& CENEVIVA, 2012).

No Brasil, após as eleições presidenciais de 2014, a Coligação Muda Brasil (PSDB/DEM/SD/PTB/PTdoB/PMN/PEN/PTC/PTN) e o Partido da Social Democracia Brasileira (PSDB) ajuizaram ação de impugnação ao mandato eletivo da presidente da República eleita Dilma Rousseff e do seu vice-presidente Michel Temer por abuso de poder político e econômico, durante esta campanha presidencial. Segundo os argumentos inferidos no voto do ministro Gilmar Mendes do Supremo Tribunal Federal, o pedido de impugnação foi baseado em indícios de abuso de poder político cometido na prática de desvio de finalidade, de acordo com a lei 8112/1990. O abuso de poder político atribuído à campanha presidencial se constituiu na "convocação em rede nacional de emissoras de radiodifusão, a fim de manipular a divulgação de indicadores socioeconômicos; o abuso cumulado com perpetração de fraude; o uso indevido de prédios e equipamentos públicos para a realização de atos próprios de campanha; e por fim, a veiculação de publicidade institucional em período vedado" (MENDES, 2015). 
Durante as eleições presidenciais de 2014, discussões sobre reforma política em geral e, em especial, o fim da reeleição, foram motivo de muitos debates e este foi publicamente defendida pelos presidenciáveis Marina Silva e Aécio Neves, os quais acreditam que esse instituto se revelou mais prejudicial que benéfico ao país. Após as eleições, a discussão sobre a reforma política retornou à agenda política com maior força. A proposta referente ao fim da reeleição para os cargos do Executivo foi aprovada no plenário da Câmara dos Deputados em primeiro turno com 452 votos favoráveis, 19 contrários e 1 abstenção. Além da rejeição da continuidade desse instituto pelo Legislativo, uma pesquisa apresentada pelo Datafolha, realizada em 2015 , infere que $67 \%$ dos brasileiros também demonstram serem contrários à reeleição para o chefe do Executivo nacional, 65\% para os governadores e 64\% para os prefeitos (DATAFOLHA, 2015).

Outro problema apontado é que a visibilidade do titular do cargo dificulta a entrada de outros candidatos na disputa eleitoral e, de certa forma, reduz as preocupações e expectativas sobre a concorrência por votos pelo atual governante (STONECASH, 2008). De acordo com Griffin (2006), as reeleições têm o papel de influenciar o político a buscar um melhor desempenho de suas funções, todavia, a expectativa de que a eleição seja vencida com facilidade poderá diminuir a representação e responsabilidade com suas políticas de governo.

Por outro lado, aqueles favoráveis à reeleição defendem que o mandato único limita a capacidade de realização de serviços e obras públicas, estimula a descontinuidade na administração pública e despreza a experiência acumulada pelo chefe do Executivo. Ademais, afirmam que a reeleição funciona como um mecanismo de controle e punição do mau governante (NERY, 2015). De fato, há argumentos teóricos que defendem a reeleição como um mecanismo gerador de transparência e de controle democrático. A literatura sobre controle eleitoral sugere que a reeleição é um instrumento disciplinador do comportamento oportunista e autointeressado dos governantes. Os eleitores punem políticos que adotam práticas contrárias ao interesse público por meio do voto (BARRO, 1973; FEREJOHN, 1986), o que leva os titulares interessados em retornar ao cargo de chefe do Executivo a se comportarem mais proximamente ao interesse dos eleitores. Sobre a condução da política físcal, vários trabalhos evidenciam teórica e empiricamente que a perspectiva de reeleição tende a aumentar a responsabilidade fiscal do governante (BESLEY \& CASE, 1995; MENEGUIN \& BUGARIN, 2001; MENEGUIN, BUGARIN \& CARVALHO, 2005).

À luz desta discussão, surge, naturalmente, a questão: qual será o efeito gerado com o fim da reeleição sobre a condução da política fiscal no país? Ao se alterar o sistema eleitoral vigente, os entes governamentais sofrerão influência do modo como os governantes conduzem suas 
contas fiscais? Neste sentido, o objetivo deste trabalho é estimar o efeito da reeleição sobre o equilíbrio fiscal dos municípios brasileiros. Para tanto, parte-se do pressuposto de que os prefeitos são agentes públicos capazes de influenciar o desempenho da política físcal do município por meio do controle das receitas (com o aumento ou corte de tributos municipais) e das despesas públicas (com a promoção de gastos públicos).

Com base na análise de painéis do comportamento fiscal dos municípios brasileiros entre 2001 e 2012, este estudo apresenta evidência econométrica que apoia a hipótese do controle eleitoral e conclui que prefeitos em primeiro mandato que concorrem à reeleição apresentam melhor desempenho fiscal do que seus pares de segundo mandato. Esse achado é particularmente importante neste momento em que caminhamos para a aprovação, no Congresso Nacional, do fim do instituto da reeleição. De fato, o fim da reeleição pode trazer consigo, como consequência adversa, o aumento do gasto público, justamente quando o país necessita urgentemente de maior disciplina fiscal dos governos, já que se está em ambiente de recessão generalizada.

O restante do trabalho está dividido conforme descrito a seguir. A próxima seção conduz a uma breve revisão sobre o modelo de controle eleitoral, destacando o modelo teórico de Meneguin e Bugarin (2001) que será a base para os testes empíricos. A seção 3 traz um breve panorama sobre a política fỉscal subnacional. A seção 4 apresenta as principais contribuições deste trabalho: o estudo econométrico pertinente e seus resultados. Por fim, a seção 5 apresenta as conclusões.

\subsection{O modelo de controle eleitoral}

O estudo sobre os determinantes políticos no comportamento fiscal dos entes governamentais é um dos temas de economia política que mais ganharam atenção nos últimos anos. Desde meados dos anos 70, várias correntes teóricas tentam justificar essa relação entre o processo eleitoral e a gestão da política fiscal, no entanto duas correntes ganharam maior destaque neste campo de estudo, a saber: os modelos de ciclos políticos e os modelos de controle eleitoral.

Ambas correntes são fundamentadas na existência de assimetria informacional entre governantes e eleitores. Nos modelos clássicos de ciclos políticos, os eleitores não conseguem observar os detalhes da política monetária de seu ente; então, os governantes, motivados pela hipótese de reeleição, são incentivados a utilizar essa política pública para elevar artificialmente o crescimento econômico, reduzindo, assim, o desemprego, em período próximo às eleições e 
garantindo sua reeleição. Os primeiros modelos de ciclos políticos foram apresentados por Nordhaus (1975), Lindbeck (1976) e MacRae (1977). Várias extensões foram sugeridas ao modelo inicial, destacando-se os estudos de Rogoff e Silbert (1988), Rogoff (1990), Person e Tabellini (1990) os quais são fundamentados no paradigma da escolha racional e partem do pressuposto de que o eleitorado só conseguirá identificar a competência do governante com uma defasagem de tempo. Desta forma, haveria fortes motivações para que o político eficiente demonstrasse sua competência, utilizando alguns instrumentos de política econômica com o intuito de estimular a economia de forma que um político incompetente não fosse capaz de imitá-lo.

Dados esses incentivos perversos, os modelos de controle eleitoral enfatizam a ideia de reeleição como um instrumento capaz de limitar a manipulação oportunista das políticas governamentais pelos detentores de poder. Tais modelos pressupõem a existência de assimetria informacional entre governantes e eleitores: estes não observam diretamente as ações dos políticos que, em consequência, ganham incentivos para adotar um comportamento oportunista e autointeressado. Formalmente, essa relação pode ser analisada nos termos de um modelo agente-principal, em que o político é o agente e o eleitor é o principal.

Os precursores dessa linha de pesquisa defendem a reeleição como um instrumento efetivo contra a corrupção e argumentam que os governantes desonestos, com o intuito de comportar-se como políticos honestos para maximizar suas chances de reeleição, tendem a postergar a sua extração de renda privada decorrente do superfaturamento de obras; por exemplo, do primeiro para o segundo mandato (BARRO, 1973; FEREJOHN, 1986). Ferejohn (1986) conclui, em seu estudo, que a possibilidade de reeleição induz o titular do cargo a se esforçar mais (o que lhe é custoso) para obter melhores resultados, quando comparado aos governantes sem esse incentivo.

Peltzman (1992) propõe um modelo que analisa a resposta do eleitor ao governo "gastador", medida por meio da política orçamentária do ente estatal. Os resultados da análise empírica mostram que os eleitores norte-americanos são avessos à elevação dos gastos e punem o governante que aumenta os gastos em anos eleitorais com a não reeleição. Seguindo essa mesma linha, Besley e Case (1995) propuseram um modelo de construção de reputação política que evidencia o papel disciplinador das eleições sobre a política fiscal dos governos e conclui que as eleições têm o papel de controlar desvios de recursos, bem como possibilitar a punição de governos oportunistas. De acordo com Besley (2006), mesmo com a existência de um sistema legal que ofereça recursos para punir abusos cometidos por políticos, o sistema eleitoral 
é considerado uma forma efetiva para a penalização daqueles políticos que apresentam um desempenho ruim e adotam práticas contrárias ao interesse público.

Em se tratando do Brasil, Ferraz e Finan (2010) apresentam resultados consistentes com esses modelos para os governos subnacionais: prefeitos com expectativas de permanecer no cargo por mais um mandato serão, em média, menos corruptos do que prefeitos sem incentivos à reeleição. Além disso, sugerem que a accountability eleitoral age como mecanismo bastante poderoso para alinhar ações dos políticos com as preferências dos eleitores.

Em oposição à principal premissa do modelo construído por Besley e Case (1995), Cavalcante (2015), ao analisar o desempenho da gestão fiscal entre prefeitos de primeiro e segundo mandatos no tocante à arrecadação própria, investimentos e gastos sociais, refuta a hipótese de que prefeitos em primeiro mandato tendem a apresentar melhores desempenhos. $\mathrm{O}$ autor interpreta que um maior esforço do prefeito em primeiro mandato também pode ser alcançado durante a segunda gestão pela experiência adquirida no mandato anterior. Isso corrobora o argumento dos defensores da reeleição, em que o mecanismo da reeleição valoriza a experiência e a continuidade administrativa.

Os autores Meneguin e Bugarin (2001) contribuem para a literatura de controle eleitoral com a construção de um modelo dinâmico, o qual mensura o efeito da reeleição nas decisões referentes aos gastos governamentais subnacionais brasileiros. Os autores demonstram que existe uma redução do benefício marginal do déficit no primeiro mandato quando a reeleição é certa e argumentam que, quanto maior a probabilidade de reeleição, menor a disposição a se ter despesas superiores às receitas, pois os encargos do déficit serão suportados pelo próprio governador em um mandato posterior. Em suma, os autores concluem que, quanto maior a chance de reeleição, menor será a disposição do governante para manter déficits fiscais, visto que os encargos desses déficits recairão sobre seu próximo mandato.

$\mathrm{Na}$ subseção seguinte, apresentar-se-á o modelo teórico desenvolvido por Meneguin e Bugarin, que é a base para os testes empíricos propostos neste trabalho.

\subsubsection{O modelo de déficit fiscal e reeleição por Meneguin e Bugarin}

O modelo proposto por Meneguin e Bugarin (2001) aqui descrito se refere a dois períodos com reeleição no término do primeiro mandato. Esse teve como base o modelo de Werneck (1995) que, para calcular o déficit fiscal ótimo dos estados, propõe uma função de utilidade do governo estadual baseada no montante das despesas agregadas do ente estatal, de forma que a satisfação do estado aumente à medida que é possível despender mais . Dessa forma teremos: 


$$
U=U(G) ; \quad U^{\prime}>0
$$

A função de utilidade $U$ é crescente em seu nível de gastos agregado $G$.

$$
G=D-r_{e} B+T
$$

$D$ representa o déficit fiscal do estado, $T$ representa a receita total estadual, $B$ a dívida interna do estado e $r_{e}$ representa a taxa de juros paga pelo estado sobre a dívida $B$.

A taxa de juros paga sobre a dívida estadual é definida como a taxa de juros paga pela União sobre seus próprios empréstimos $\left(r_{u}\right)$, essa é somada a uma taxa extra $(r)$ que representa um risco maior inerente ao estado, sendo que esse acréscimo é função crescente do déficit estadual e decrescente da relação receita/dívida interna:

$$
r_{e}=r_{u}+r\left(D, \frac{T}{B}\right)
$$

De acordo com a igualdade acima, à medida que o déficit estadual aumenta, o estado deve pagar um maior serviço da dívida, o que diminui a quantidade de recursos disponíveis para gastos e, dessa forma, o governo terá de ter um controle das políticas fiscais para garantir um nível de déficit que maximize suas despesas.

Agora, considere que a satisfação do estado, a qual é refletida no governante, é a soma das utilidades provenientes da despesa agregada dos dois períodos. $\mathrm{O}$ índice $i$ representa o último exercício do primeiro mandato e o índice $n$ representa o primeiro ano do segundo mandato do governante, na hipótese de o governante ter alcançado a reeleição. Além disso, o modelo considera exógena a probabilidade de o governador ser reeleito, $\rho \in[0,1]$. Dessa forma, o problema de maximização pode ser expresso como:

$$
\begin{gathered}
\max _{D_{i}, D_{n}} U\left(G_{i}\right)+\rho \delta U\left(G_{n}\right) \\
\text { S.a. } \\
\left\{\begin{array}{l}
G_{i}=D_{i}-r_{e i} B_{i}+T \\
G_{n}=D_{n}-r_{e n} B_{n}+T \\
r_{e i}=r_{u}+r\left(D_{i}, \frac{T}{B_{i}}\right) \\
r_{e n}=r_{u}+r\left(D_{n}, \frac{T}{B_{n}}\right) \\
B_{n}=B_{i}+D_{i}
\end{array}\right.
\end{gathered}
$$

As condições de primeira ordem levam aos seguintes resultados:

$$
B_{n} \frac{\partial r}{\partial D_{n}}\left(D_{n}, \frac{T}{B_{n}}\right)=1
$$




$$
B_{i} \frac{\partial r}{\partial D_{i}}\left(D_{i}, \frac{T}{B_{i}}\right)=1-\delta \cdot \rho \cdot\left(\frac{U \prime\left(G_{n}\right)}{U \prime\left(G_{i}\right)}\right) \cdot\left(r_{e n}-\frac{T}{B_{n}} \cdot \frac{\partial r}{\partial \frac{T}{B_{n}}}\left(D_{n}, \frac{T}{B_{n}}\right)\right)
$$

A intuição econômica dos resultados acima pode ser vista da seguinte forma: as expressões da esquerda retratam o custo marginal de o governo se endividar no primeiro mandato, enquanto a expressão da direita reflete o ganho adicional com o aumento de uma unidade da dívida, também no primeiro mandato.

O resultado (1) significa que, à medida que o governante se aproxima do último exercício, a satisfação adicional gerada pelo déficit aumenta e os incentivos para que os governos se endividem sejams $\underline{\text { ão }}$ maiores ao final de seus mandatos e menores durante o início.

A Tabela 1.1 resume os possíveis resultados da expressão (2) de acordo com o valor do parâmetro $\rho$.

Tabela 1.1 - Resultados do modelo desenvolvido por Meneguin e Bugarin (2001)

\begin{tabular}{ccc}
\hline $\boldsymbol{\rho}$ & Benefício Marginal do Déficit & Reeleição \\
\hline $\mathbf{0}$ & 1 & Não \\
$\mathbf{0}<\boldsymbol{\rho}<\mathbf{1}$ & $1-\delta \cdot \rho \cdot\left(\frac{U^{\prime}\left(G_{n}\right)}{U^{\prime}\left(G_{i}\right)}\right) \cdot\left(r_{e n}-\frac{T}{B_{n}} \cdot \frac{\partial r}{\left.\partial \frac{T}{B_{n}}\left(D_{n}, \frac{T}{B_{n}}\right)\right)}\right.$ & Incerta \\
$\mathbf{1}$ & $1-\delta\left(\frac{U^{\prime}\left(G_{n}\right)}{U^{\prime}\left(G_{i}\right)}\right) \cdot\left(r_{e n}-\frac{T}{B_{n}} \cdot \frac{\partial r}{\partial \frac{T}{B_{n}}}\left(D_{n}, \frac{T}{B_{n}}\right)\right)$ & Sim \\
\hline
\end{tabular}

Fonte: Meneguin e Bugarin (2001).

Os autores, inicialmente, chamam atenção para o fato de a desigualdade (3) abaixo ser sempre verdadeira, dado que $\rho \in[0,1]$ :

$$
1-\delta \cdot \rho \cdot\left(\frac{\mathrm{U} /\left(\mathrm{G}_{\mathrm{n}}\right)}{\mathrm{U} /\left(\mathrm{G}_{\mathrm{i}}\right)}\right) \cdot\left(\mathrm{r}_{\mathrm{en}}-\frac{\mathrm{T}}{\mathrm{B}_{\mathrm{n}}} \cdot \frac{\partial \mathrm{r}}{\partial \frac{\mathrm{T}}{\mathrm{B}_{\mathrm{n}}}}\left(\mathrm{D}_{\mathrm{n}}, \frac{\mathrm{T}}{\mathrm{B}_{\mathrm{n}}}\right)\right) \geq 1-\delta\left(\frac{\mathrm{U} /\left(\mathrm{G}_{\mathrm{n}}\right)}{\mathrm{U} /\left(\mathrm{G}_{\mathrm{i}}\right)}\right) \cdot\left(\mathrm{r}_{\mathrm{en}}-\frac{\mathrm{T}}{\mathrm{B}_{\mathrm{n}}} \cdot \frac{\partial \mathrm{r}}{\partial \frac{\mathrm{T}}{\mathrm{B}_{\mathrm{n}}}}\left(\mathrm{D}_{\mathrm{n}}, \frac{\mathrm{T}}{\mathrm{B}_{\mathrm{n}}}\right)\right)
$$

Eles concluem que há uma redução do benefício marginal do déficit no primeiro mandato quando a reeleição é um evento certo. Além disso, sugerem que, quanto maior a probabilidade de reeleição, menor será o incentivo à produção de gastos acima do nível das receitas, pois esse déficit será sentido pelo próprio governante no próximo mandato. 


\subsection{Panorama da política fiscal subnacional}

Os rumos para o desenvolvimento de qualquer sociedade são bastante influenciados pelas políticas e pelo conjunto de medidas adotadas pelo governo, em particular, aquelas para a obtenção de recursos necessários à cobertura dos gastos públicos. O governo visa cumprir três importantes funções por meio da arrecadação de receitas e da realização de despesas: a estabilização macroeconômica, a redistribuição da renda e a alocação de recursos (MUSGRAVE, 1976). Nesse sentido, o equilíbrio das contas públicas é fundamental para prevenir a ocorrência de déficits sucessivos, bem como o aumento do nível de endividamento. Deste modo, prevenir-se-á uma consequente crise financeira, que poderia dificultar o cumprimento das funções fiscais pelo governo.

O papel exercido pelos municípios perante o processo de desenvolvimento com sustentabilidade é de extrema importância. Entre outros aspectos, a criação da renda e da riqueza nacionais acontece dentro das figuras municipais. A grosso modo, a gestão financeira municipal caracteriza-se pelos procedimentos empregados na obtenção e na administração de recursos financeiros obtidos por meio da arrecadação dos tributos de competência do município, da exploração do patrimônio local e da participação da distribuição das receitas dos governos estadual e federal, com o objetivo de prestar serviços públicos diretamente ao cidadão executados por meio de despesas públicas (GERIGK, CLEMENTE \& TAFAREL, 2010). Assim, é de competência do governo municipal arrecadar receitas sufici entes para financiar as despesas necessárias para prover bens e serviços públicos aos cidadãos.

As contas do setor público consolidado - que englobam a União, os estados, os municípios e as empresas estatais - registraram, recentemente, um caminho de queda nos resultados das contas primárias. De acordo com dados do Banco Central do Brasil, essas contas registraram um déficit primário em 2014, após vários anos de contas primárias positivas. Essa queda mais acentuada no desempenho das contas primárias, que se inicia em 2013 e continua em 2015, é influenciada pelos baixos resultados do governo federal. Segundo dados da Secretaria do Tesouro Nacional (STN) (Gráfico 1.1), a União registrou em 2011 um decréscimo em seu resultado primário e o pior resultado, desde 1998, foi registrado em 2015, com aproximadamente $-1,5 \%$ do Produto Interno Bruto nacional (PIB). 
Gráfico 1.1 - Resultados primários do governo federal (em proporção ao Produto Interno Bruto - PIB) - 1997-2015

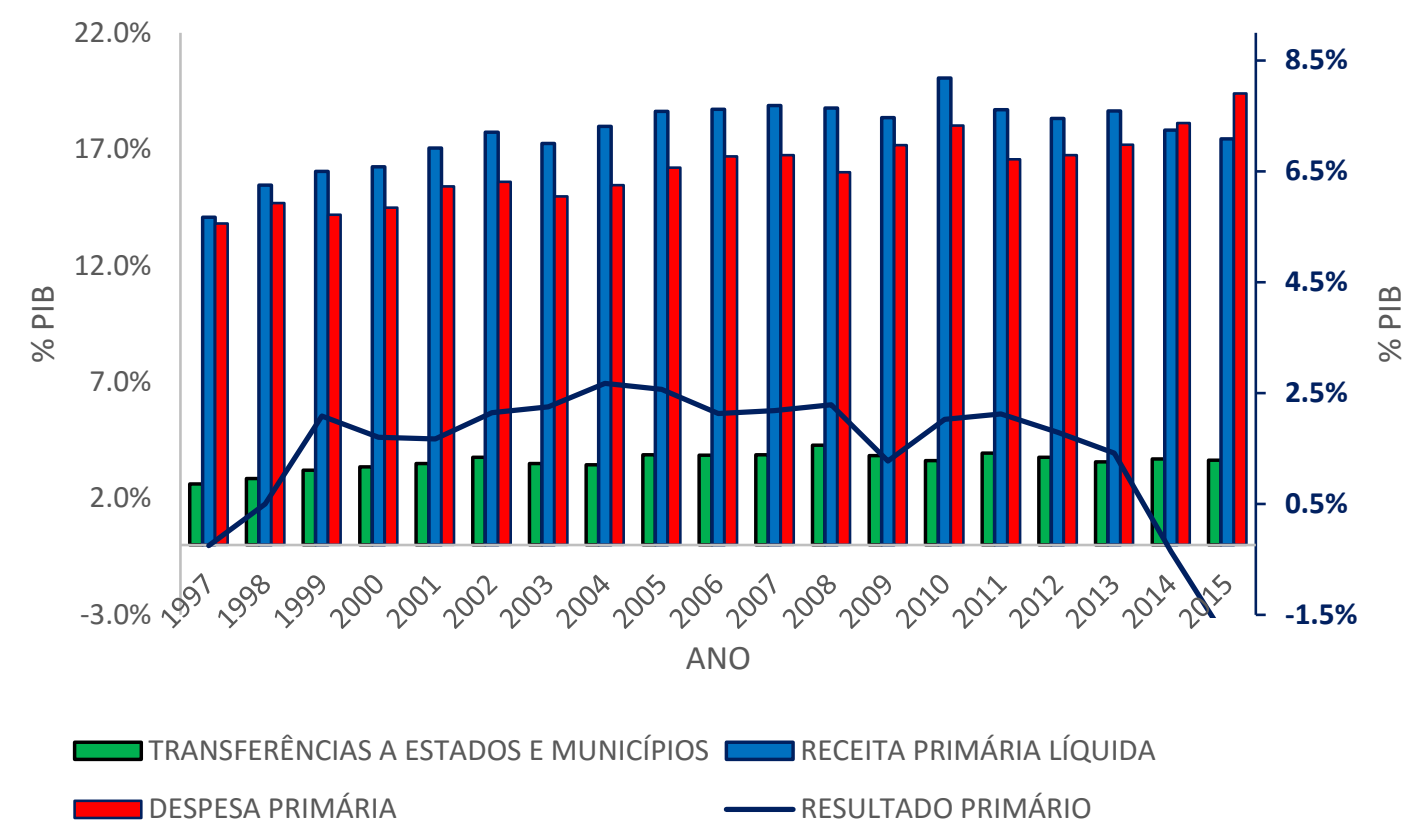

Fonte: Secretaria do Tesouro Nacional (2015).

Nota: O gráfico apresenta dois eixos: o eixo principal (lado esquerdo do gráfico) se refere às despesas primárias, às receitas primárias líquidas e ao investimento pelo PIB nacional (\%). O eixo secundário (lado direito do gráfico) se refere ao resultado primário, também, em razão do PIB nacional (\%).

A deterioração das contas públicas no âmbito dos estados e municípios também teve uma grande influência negativa no mau desempenho apresentado pelo setor público consolidado. De acordo com Mendes (2013), a partir de 2012, o governo federal começou a flexibilizar seus pareceres acerca da capacidade de endividamento dos estados e com isso permitiu o aumento das dívidas de entes que já estavam bastante endividados. Essa flexibilização almejou estimular o crescimento econômico por meio do aumento de investimentos em infraestrutura. Contudo, levou a uma deterioração das condições fiscais dos estados sem necessariamente produzir ganhos significativos na qualidade de infraestrutura. Outro fator importante para essa deterioração foi o efeito das reduções de arrecadação de tributos, a qual foi muito afetada pelas desonerações de tributos anunciadas nos últimos anos pelo governo federal (MARTELLO, 2015). As desonerações federais têm um impacto visível nas contas estaduais e no intervalo entre 2008 e 2013 significaram R $\$ 229$ bilhões de Reais a menos para os estados, o que impacta diretamente os resultados fiscais dos governos subnacionais.

Nota-se no Gráfico 1.2 que os municípios atingiram o maior nível de superávit primário, do período analisado, no ano 2005 com 0,4\% do Produto Interno Bruto (PIB) nacional - quase 0,5 pontos percentuais acima do observado no ano de 2003. Após 2005, os municípios 
apresentaram uma tendência a decréscimo chegando a -0,3\% do PIB nacional em 2012. Entre os anos de 2008 e 2009, nota-se que os municípios, em média, saíram de uma posição poupadora para uma posição deficitária e essa tendência de decaimento seguiu até o ano 2012. Pode-se inferir que, assim como a União, essa deterioração fiscal, iniciada em 2008, ocorreu pela combinação de um menor dinamismo das receitas com a manutenção do crescimento das despesas em um patamar mais elevado. Tanto as receitas quanto as despesas primárias apresentam uma tendência de crescimento e ambas partem de um valor de pouco mais de $6 \%$ do PIB nacional em 2001 para mais de 8\% do PIB em 2012.

Gráfico 1.2 - Análise gráfica do resultado primário municipal pelo Produto Interno Bruto (PIB) nacional - 2001-2012

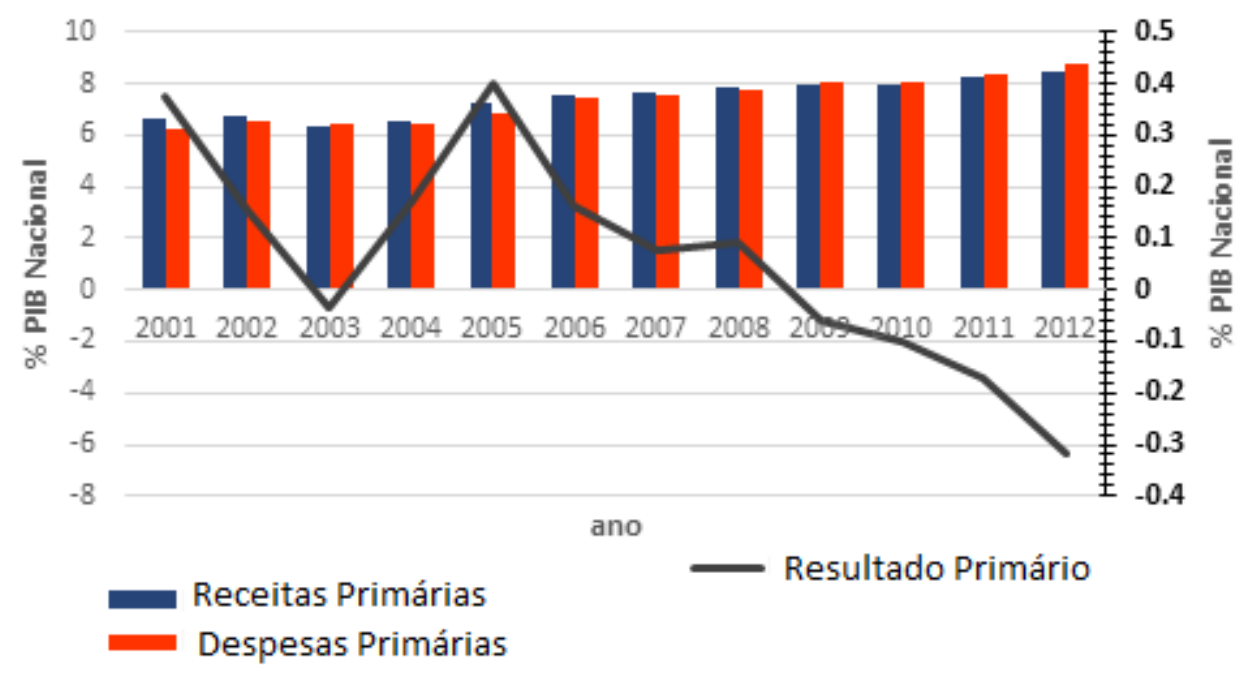

Fonte: Secretaria do Tesouro Nacional (2015).

Nota: O gráfico possui 2 eixos: o eixo principal (lado esquerdo do gráfico) se refere às receitas primárias e às despesas primárias municipais, em relação ao PIB nacional (\%). O eixo secundário (lado direito do gráfico) se refere ao resultado primário municipal também em relação ao PIB nacional (\%).

A Lei de Responsabilidade Fiscal - LRF é uma instituição orçamentária cuja estabelece normas de finanças públicas voltadas para a responsabilidade na gestão fiscal. Ela concentra de forma explícita, suas atenções na aproximação e na consolidação do equilíbrio das contas públicas (BRASIL, 2000). Este trata, fundamentalmente, do equilíbrio financeiro que exige do gestor público a observância de limites, de condições e de parâmetros no que se refere à receita e à despesa, a fim de prevenir a ocorrência de déficits sucessivos em contas governamentais. Situações de descontrole têm impacto nas condições gerais do país, bem como são perversas ao gerarem mais inflação e comprometerem a estabilidade de preços, o que prejudica, sobretudo, a população de baixa renda, a qual não pode se proteger da desvalorização da moeda. 
Em geral, os municípios possuem um orçamento bastante rígido decorrente, em especial, das despesas mínimas obrigatórias em saúde, em educação e dos gastos com pagamento de pessoal. Essa rigidez das contas públicas dificulta a implantação de cortes orçamentários, bem com a realização de investimentos necessários para o bem-estar da população.

A educação é “ direito de todos e dever do Estado e da família”, conforme dispõe o art. 205 da Constituição Federal de 1988 e, dessa forma, o Estado deve garantir a aplicação de recursos públicos mínimos para a manutenção e o desenvolvimento do ensino, peça fundamental para o crescimento do Brasil. Nesse contexto, foram fixados limites constitucionais mínimos da receita resultante de impostos em educação: limite mínimo de 18\% para o governo federal, $25 \%$ para os governos estaduais e municipais, sendo que desses $25 \%$, $60 \%$ deverão ser destinados ao financiamento do ensino fundamental e os $40 \%$ restantes ao financiamento de outros níveis de ensino. Já na saúde, o legislador definiu uma porcentagem mínima de $15 \%$ da arrecadação dos impostos municipais (BRASIL, 1988).

Um dos grandes problemas brasileiros enfrentados hoje é o fato de os investimentos em educação, em saúde e em infraestrutura urbana estarem à margem do orçamento municipal, cada vez mais comprometido com as despesas referente a funcionalismo público e sensível à redução das transferências dos estados e da União.

O gasto com pessoal ativo e inativo, apesar de ser uma despesa rígida, pelo fato de não ser possível reduzir (em curto espaço de tempo) ou recusar o pagamento de salários e aposentadorias, representa o principal item das despesas do setor público brasileiro. $\mathrm{O}$ comprometimento excessivo das receitas com esse tipo de despesa resulta na redução de recursos destinados a outros fins tais como investimentos em saúde, educação, segurança pública, transporte público dentre outros - despesas essas que fomentam as atividades econômicas e garantem o crescimento econômico sustentado da economia local e, sobretudo, geram bem-estar à população.

A Lei de Responsabilidade Fiscal (LRF) fixa um limite prudencial e um limite teto para as despesas totais com pessoal nos municípios em $57 \%$ e $60 \%$ da receita corrente líquida, respectivamente. $\mathrm{O}$ estabelecimento desses percentuais mostra a preocupação em encontrar um equilíbrio entre o custeio da máquina administrativa local e o aporte de investimentos para o atendimento das necessidades sociais locais. Além disso, essa limitação imposta visa contribuir para a promoção de uma mudança de postura institucional e cultural ao longo do tempo, de forma que este limite contribua para que esta razão caia a níveis que permita a geração de superávits. 
No entanto, mesmo com as restrições provenientes da Lei de Responsabilidade Fiscal, pode-se notar na Tabela 1.2 que, com o passar dos anos, os municípios comprometeram parcelas cada vez maiores dos seus orçamentos com o pagamento do funcionalismo público. Durante o período de 2001 a 2012, o conjunto dos municípios comprometeu, em média, 49\% de suas receitas correntes líquidas com o pagamento de pessoal. Percebe-se dos dados que o gasto médio total segue uma tendência de crescimento anual. $O$ gasto médio entre os limites prudenciais e o gasto médio abaixo desse limite têm pouca variação e, diferentemente, os gastos dos municípios acima do teto são bastante instáveis.

Tabela 1.2 - Porcentagem de municípios e porcentagem da média de gastos divididas em três grupos com referência aos limites de gastos de pessoal - 2001-2012

\begin{tabular}{|c|c|c|c|c|c|c|c|}
\hline \multirow{2}{*}{ Ano } & \multicolumn{2}{|c|}{ Abaixo do Prudencial ${ }^{/ 1}$} & \multicolumn{2}{|c|}{ Prudencial $^{13}$} & \multicolumn{2}{|c|}{ Acima do Teto ${ }^{12}$} & \multirow{2}{*}{ Total $^{/ 4}$} \\
\hline & $\%$ municípios & Média Gasto & $\%$ municípios & Média Gasto & \% municípios & Média Gasto & \\
\hline 2001 & $70,30 \%$ & $45,80 \%$ & $8,90 \%$ & $58,40 \%$ & $20,80 \%$ & $68,60 \%$ & $51,70 \%$ \\
\hline 2002 & $93,70 \%$ & $42,00 \%$ & $2,00 \%$ & $58,30 \%$ & $4,30 \%$ & $81,20 \%$ & $44,00 \%$ \\
\hline 2003 & $88,30 \%$ & $44,50 \%$ & $4,80 \%$ & $58,20 \%$ & $6,90 \%$ & $74,40 \%$ & $47,20 \%$ \\
\hline 2004 & $95,70 \%$ & $40,80 \%$ & $1,00 \%$ & $58,30 \%$ & $3,30 \%$ & $83,90 \%$ & $42,40 \%$ \\
\hline 2005 & $92,30 \%$ & $43,00 \%$ & $2,40 \%$ & $58,20 \%$ & $5,30 \%$ & $91,40 \%$ & $45,90 \%$ \\
\hline 2006 & $92,40 \%$ & $44,40 \%$ & $3,10 \%$ & $58,30 \%$ & $4,60 \%$ & $88,70 \%$ & $46,80 \%$ \\
\hline 2007 & $91,00 \%$ & $44,70 \%$ & $3,40 \%$ & $58,20 \%$ & $5,60 \%$ & $84,20 \%$ & $47,40 \%$ \\
\hline 2008 & $90,80 \%$ & $43,50 \%$ & $1,90 \%$ & $58,20 \%$ & $7,20 \%$ & $106,20 \%$ & $48,40 \%$ \\
\hline 2009 & $80,90 \%$ & $47,70 \%$ & $8,60 \%$ & $58,30 \%$ & $10,40 \%$ & $71,50 \%$ & $51,10 \%$ \\
\hline 2010 & $84,20 \%$ & $47,90 \%$ & $7,10 \%$ & $58,40 \%$ & $8,70 \%$ & $70,40 \%$ & $50,60 \%$ \\
\hline 2011 & $87,00 \%$ & $46,90 \%$ & $5,60 \%$ & $58,30 \%$ & $7,40 \%$ & $93,80 \%$ & $51,00 \%$ \\
\hline 2012 & $76,50 \%$ & $47,90 \%$ & $8,60 \%$ & $58,30 \%$ & $14,90 \%$ & $77,30 \%$ & $53,10 \%$ \\
\hline
\end{tabular}

Fonte: Dados Finbra. Tabela elaborada pela autora.

Notas: ${ }^{11}$ A coluna " $<$ Prudencial" corresponde aos municípios com gastos de pessoal até $57 \%$ da receita corrente líquida. 12 A coluna " $>$ Teto" corresponde aos municípios com gastos de pessoal acima de $60 \%$ da receita corrente líquida.

${ }^{13}$ A coluna "Prudencial" corresponde aos municípios com gastos de pessoal entre $57 \%$ e $60 \%$ da receita corrente líquida.

${ }^{14}$ A coluna "Total" corresponde à média dos gastos de todos os municípios da base.

Além dos gastos médios, pode-se notar na Tabela 1.2 que a quantidade de municípios que orbitam o conjunto dos municípios com gastos acima do teto aumentou bastante nos últimos anos. Destaque deve ser dado ao ano de 2012 quando praticamente se duplicou a quantidade de municípios neste conjunto. Pode-se inferir dos dados que houve uma migração dos municípios para as classes de altos gastos, isto é, esse movimento sugere que os municípios que gastavam uma pequena parcela da sua receita corrente líquida com pessoal aumentaram seus gastos.

O Gráfico 1.3 apresenta a relação dos gastos de pessoal da administração pública local e os gastos com investimento de capital em proporção às receitas correntes líquidas. Infere-se dele que pelo elevado comprometimento das receitas municipais com os gastos com pessoal, 
resta pouco espaço para gastos com investimentos. Nota-se que os gastos com investimento giram em torno de $12 \%$ das receitas correntes líquidas municipais.

Gráfico 1.3 - Análise gráfica da despesa com pessoal e receita corrente líquida

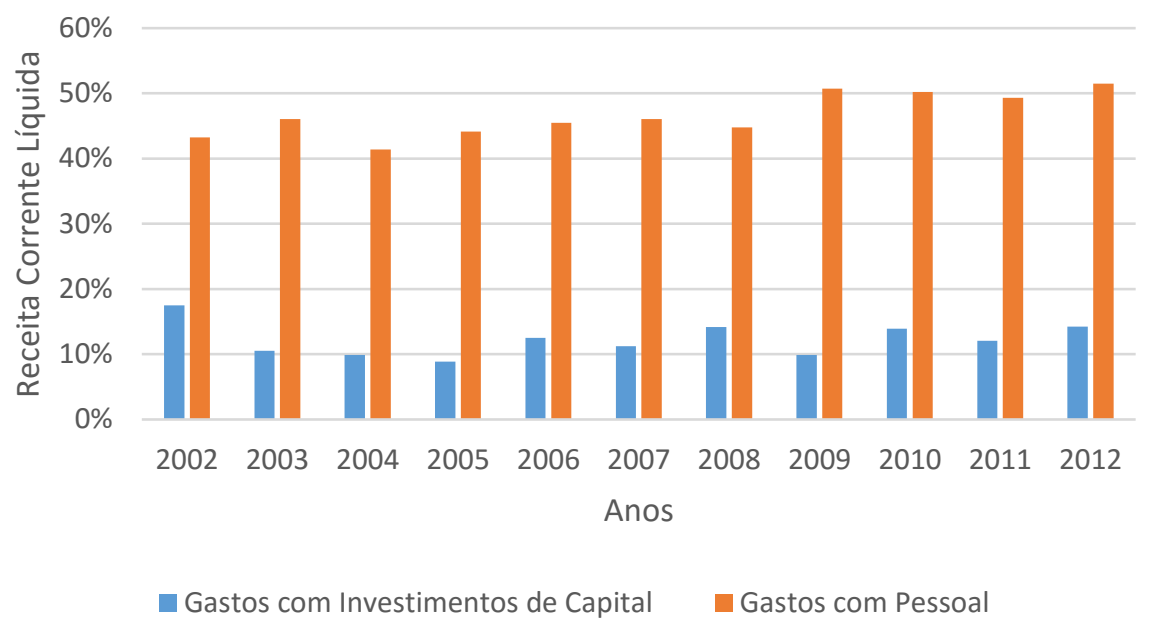

Fonte: Secretaria do Tesouro Nacional_. Elaborado pela autora.

Com a Constituição Federal de 1988 e o status de participante ativo nas competências tributárias do país, aos municípios foram concedidas competências para legislar, coletar impostos e fixar alíquotas (BRASIL, 1988). No entanto, ainda há uma dependência dos recursos transferidos pelos governos federal e estadual. Em média, apenas 12,7\% das receitas municipais são recursos próprios e o restante são provenientes de transferências dos estados e do governo federal.

O perfil das receitas municipais varia, via de regra, em função das peculiaridades locais. No que se refere às transferências de recursos dos estados e da União, por exemplo, a participação no Imposto sobre a Circulação de Mercadorias e Serviços (ICMS) tende a ser a mais substancial nos municípios mais desenvolvidos, enquanto os recursos provenientes do Fundo de Participação Municipal (FPM) constituem a principal fonte de receita dos municípios menores e mais pobres. Além disso, visto que o fato gerador dos impostos municipais está intimamente relacionado com características de desenvolvimento econômico e urbano propriedades prediais e territoriais no caso do Imposto Predial e territorial urbano (IPTU) e valores sobre prestação de serviços no caso do Imposto sobre Serviços (ISS) - a receita tributária tende a ter mais representatividade em municípios mais ricos e desenvolvidos. $\mathrm{O}$ Gráfico 1.4 apresenta as médias das razões entre as receitas dos municípios e as respectivas receitas correntes líquidas. 
Gráfico 1.4 - Divisão das receitas públicas municipais em proporção da receita corrente líquida.

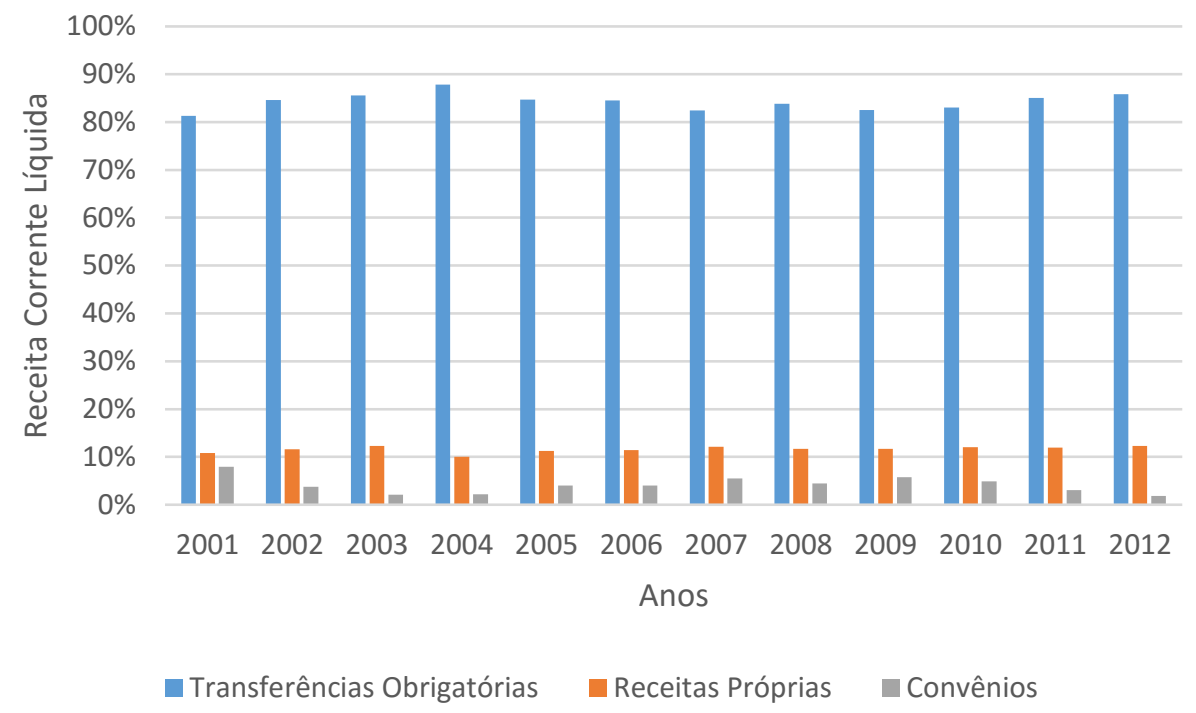

Fonte: Secretaria do Tesouro Nacional. Elaborado pela autora.

Em relação à receita corrente líquida dos municípios, observa-se um maior volume das receitas provenientes de transferências dos entes supranacionais: em média $84 \%$ das receitas correntes líquidas se referem às transferências constitucionais e obrigatórias. Além disso, em média as prefeituras não são capazes de gerar mais do que $12 \%$ de suas receitas.

$\mathrm{Na}$ Figura 1.1, quanto mais escura a região, maior é a receita própria local como percentual da receita total, variando de 5\% (mais clara) até mais de 50\% (mais escura). Notase que no intervalo de onze anos as regiões Norte, Nordeste e Centro-Oeste apresentaram um substancial aumento na arrecadação tributária. No entanto, pode-se observar que parte significante dos municípios do Norte e do Nordeste ainda possuem uma arrecadação média abaixo de $5 \%$ da receita corrente líquida. 
Figura 1.1 - Distribuição espacial da proporção entre receitas próprias e a receita corrente líquida.
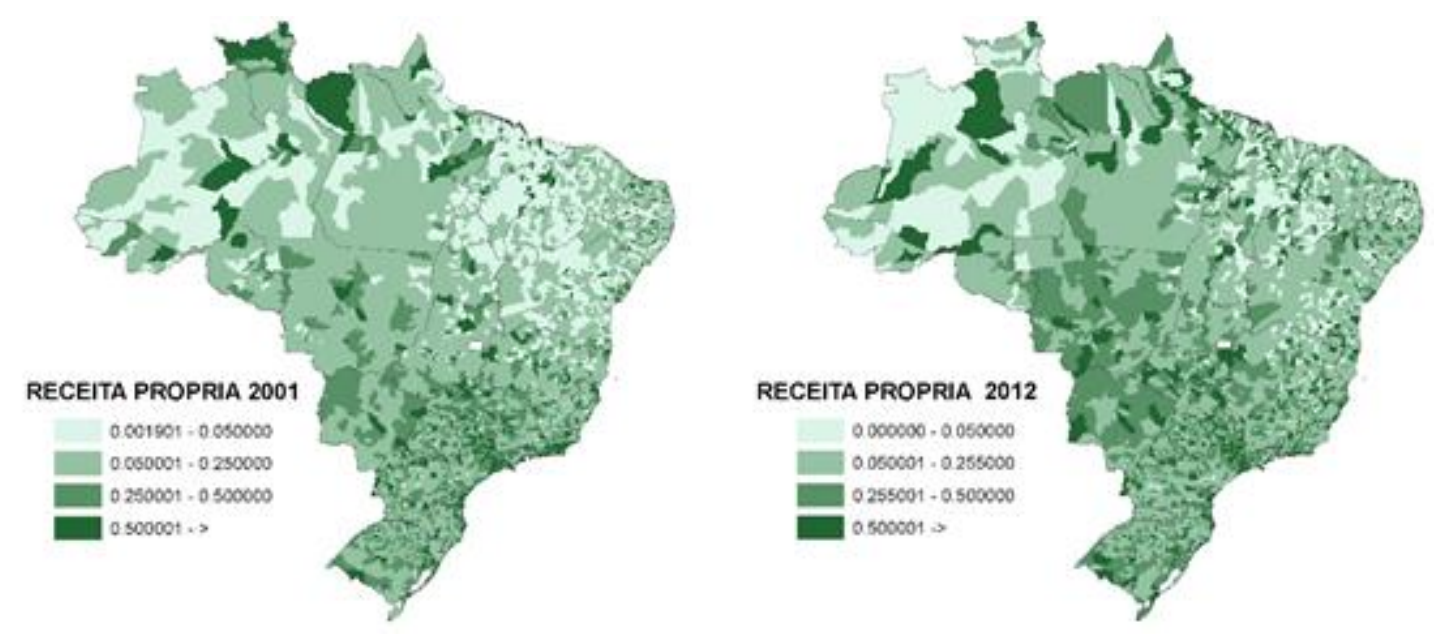

Fonte: Secretaria do Tesouro Nacional. Elaborado pela autora.

\subsection{Análise econométrica: o efeito da reeleição sobre o comportamento fiscal nos municípios}

Com o intuito de estudar as influências políticas sofridas pela política fiscal municipal, este trabalho pretende analisar empiricamente a influência da reeleição do Executivo local na sustentabilidade fiscal do ente. Com esse objetivo, pretende-se responder a seguinte pergunta de pesquisa: prefeitos em primeiro mandato com expectativas de reeleição são mais cautelosos com as finanças públicas municipais do que seus pares de segundo mandato, ou mesmo os que estão em primeiro mandato sem perspectivas de reeleição? Além dessa análise principal, pretende-se analisar se esse desempenho fiscal é também influenciado por outras condições políticas do ente (a existência de um concorrente com força política, o apoio do governador do estado, o apoio do presidente da República e a fragmentação do Legislativo local), pelas características locais do município (taxa de analfabetismo, taxa de mortalidade e proporção da população economicamente ativa), e pelas características pessoais do prefeito (idade, grau de instrução e sexo).

Neste trabalho optou-se por avaliar os possíveis impactos da reeleição na gestão fiscal municipal por dois enfoques distintos: modelos clássicos de dados em painel e uma análise utilizando a metodologia de diferenças em diferenças. As variáveis dependentes $\left(\right.$ Fiscal $\left._{i t}\right)$ são indicadores fiscais do município $i$ no ano $t$ e os coeficientes das variáveis que identificam os prefeitos de primeiro mandato com expectativas de reeleição e os prefeitos de primeiro mandato sem expectativas eleitorais, $G_{1}$ e $G_{2}$ respectivamente, são os parâmetros de interesse do trabalho. 
A Figura 1.2 mostra a divisão em quatro grupos de prefeitos utilizada nas análises econométricas desse capítulo:

$G_{0}$ - Grupo dos prefeitos em primeiro mandato.

$G_{1}-$ Grupo dos prefeitos de primeiro mandato que tentaram reeleição $\left(G_{1} \subset G_{0}\right)$.

$G_{2}$ - Grupo dos prefeitos de primeiro mandato que não tentaram a reeleição na eleição subsequente $\left(G_{2} \subset G_{0}\right)$.

$G_{3}-$ Grupo dos prefeitos que estão em segundo mandato $\left(G_{3} \cap G_{0}=\emptyset\right)$.

Figura 1.2 - Diagrama dos grupos de prefeitos

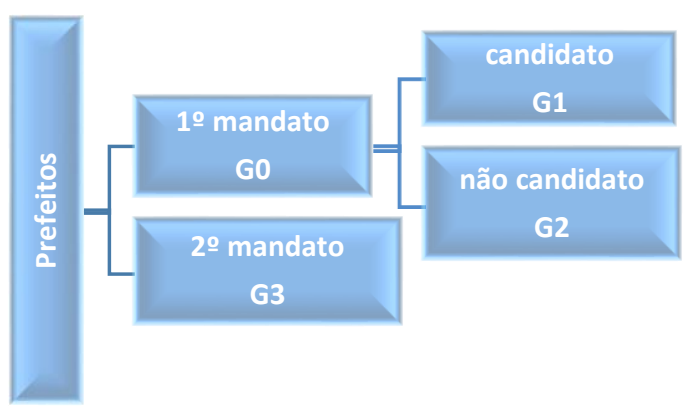

Fonte: Elaborado pela autora.

Dessa forma, a variável dummy $G_{1}$ será igual a 1 (um) se o prefeito é de primeiro mandato e, além disso, se ele será candidato a reeleição na próxima eleição, e 0 (zero) caso contrário. Essa variável é uma proxy para prefeitos de primeiro mandato com expectativas de se reelegerem na próxima eleição. A variável dummy $G_{2}$ será igual a 1 (um) se o prefeito é de primeiro mandato e, no entanto, não tentou a reeleição, e 0 (zero) caso contrário. Essa variável será uma proxy para os prefeitos de primeiro mandato que não vislumbram um segundo mandato no cargo. A variável $G_{3}$ é a variável oculta correspondente aos prefeitos em segundo mandato que por lei não podem se candidatar à reeleição. Portanto, uma significância estatística em qualquer dos coeficientes das variáveis $G_{1}$ ou $G_{2}$ significa um comportamento distinto do prefeito em primeiro mandato em comparação com o prefeito em segundo mandato.

Para as duas estratégias empíricas, espera-se que a variável $G_{1}$ apresente um efeito positivo sobre o saldo do resultado primário, indicando a capacidade de os governos gerarem receitas em volume suficiente para pagarem suas contas usuais sem comprometerem as contas do próximo mandato. Já para os prefeitos em $G_{2}$ o efeito esperado é inexistente, ou seja, prefeitos em primeiro mandato que não vislumbram reeleição se comportam como prefeitos em segundo mandato que não podem ser reeleitos. 


\subsubsection{Variáveis dependentes}

Dentre as várias formas de se medir o desempenho governamental, optou-se por utilizar medidas de contas primárias, pois são consideradas um dos principais indicadores utilizados pelo governo brasileiro. Esta pesquisa utilizou como principal indicador a conta de resultado primário municipal que é considerado um dos melhores sinalizadores da saúde financeira e objetiva medir o comportamento fiscal do governo durante o exercício. De acordo com Albuquerque, Medeiros e Feijó (2008), a apuração dessa conta avalia a sustentabilidade da política fiscal, ou seja, a capacidade de geração de receitas em volume suficiente para pagar suas contas usuais (despesas correntes e investimentos), sem que se comprometa sua capacidade de administrar a dívida existente.

Esse resultado é definido como a diferença entre as receitas primárias e as despesas primárias. Entende-se por receita primária (ou receita não financeira), aquelas decorrentes da atividade fiscal do governo, incluindo, entre outras, as receitas tributárias e de contribuições sociais e aquelas condicionadas à aprovação de dispositivos legais das quais se subtraem as receitas financeiras (receitas derivadas de aplicações no mercado financeiro e de privatizações, bem como a rolagem e emissão de títulos). Da mesma forma, por despesas primárias (ou despesas não financeiras) entende-se o total das despesas orçamentárias (correntes e de capital) deduzidas as despesas financeiras, ou seja, subtraem-se os encargos e amortização da dívida.

Por não considerar os encargos da dívida existente, o resultado primário evidencia o esforço fiscal do setor público sem considerar as ações financeiras incorridas nos anos anteriores, já que as despesas líquidas com juros dependem do estoque total da dívida pública e das taxas de juros que incidem sobre esse estoque. Assim, a inclusão dos juros no cálculo dificultaria a mensuração do efeito da política fiscal executada pelo governo, motivo pelo qual se calcula o resultado primário do setor público. Em resumo, sua finalidade é verificar se os níveis dos gastos orçamentários do governo são compatíveis com a arrecadação e, sobretudo, se os recursos são capazes de garantir o pagamento das dívidas de longo prazo. Se o setor público gasta menos do que arrecada, sem considerar as taxas de juros incorridas sobre a dívida existente, há superávit primário. Caso contrário, há déficit primário.

Segundo Alesina e Perotti (1995), a utilização do indicador resultado primário tem como vantagem sua simplicidade, apesar da desvantagem de não considerar a influência de flutuações cíclicas sobre as distintas categorias de receitas e despesas que o definem. Para tentar minimizar esse problema, a razão resultado primário sobre Produto Interno Bruto (PIB) municipal também será analisada em conjunto com outras regressões que serão usadas como parâmetro de 
comparação: receitas primárias, arrecadação municipal, transferências voluntárias (via convênios públicos com a União), despesas primárias, gasto com pessoal, gastos com investimentos de capital, gastos com social. Todas as equações serão construídas em razão do PIB municipal. O Quadro 1.1 sintetiza as descrições das variáveis utilizadas.

Quadro 1.1 - Variáveis dependentes utilizadas nos testes empíricos

\begin{tabular}{|l|l|l|}
\hline Testes & Variável Dependente & \multicolumn{1}{c|}{ Descrição } \\
\hline Teste1 & Resultado Primário & $\begin{array}{l}\text { Diferença entre receita primária e despesa primária em percentual do } \\
\text { PIB municipal. }\end{array}$ \\
\hline Teste2 & Receita Primária & Receita primária municipal em porcentagem do PIB municipal \\
\hline Teste3 & Despesa Primária & Despesa primária municipal em porcentagem do PIB municipal \\
\hline Teste4 & Receita Própria & Arrecadação municipal em porcentagem do PIB municipal \\
\hline Teste5 & Transf. Voluntária & $\begin{array}{l}\text { Convênios firmados entre União e municípios em porcentagem do PIB } \\
\text { municipal. }\end{array}$ \\
\hline Teste6 & Gasto com Pessoal & Gastos com Pessoal em porcentagem do PIB. \\
\hline Teste7 & Gasto Investimento & Gastos com Investimento de capital em porcentagem do PIB. \\
\hline Teste8 & Gastos Social & $\begin{array}{l}\text { Gastos com Saúde, Saneamento Básico, Educação e Cultura em } \\
\text { porcentagem do PIB municipal. }\end{array}$ \\
\hline
\end{tabular}

Fonte. Elaborado pela autora.

\subsubsection{Variáveis de controle}

Além do efeito das variáveis de interesse, estamos interessados no efeito parcial das variáveis de controle sobre as variáveis dependentes e, para facilitar as análises, dividimos as variáveis independentes em três grupos distintos: outras características políticas, características pessoais do prefeito e características sociais.

\subsubsection{Outras variáveis políticas}

Este conjunto de variáveis pretende medir a influência de características políticas dos municípios no andamento da política fiscal local. Estas variáveis foram construídas com dados do Tribunal Superior Eleitoral (TSE) para as eleições de 2000 a 2012:

Alinhamento Político Partidário: O Alinhamento político partidário entre o prefeito do município $i, p_{i}$, e os chefes do executivo dos outros níveis de governo é medido por meio de uma variável dummy que receberá o valor 1 (um) se os governantes são do mesmo partido e 0 (zero) caso contrário. A inclusão dessa variável tem a finalidade de investigar se a identificação política entre o chefe do executivo municipal e os chefes do executivo dos outros níveis de governo, assim como de suas coalizões, têm influência nos resultados da gestão fiscal municipal. Espera-se um efeito positivo no resultado primário. 
Fragmentação do Legislativo (frag): A variável que representa a fragmentação da câmara legislativa municipal visa medir a influência da coesão/dispersão das preferências dos partidos políticos sobre o desempenho físcal. O grau de fragmentação das câmaras legislativas municipais foi baseado no trabalho de Rae (1971). A variável traduz o grau de concentração dos partidos políticos que compõe a câmara dos vereadores e quanto mais próximo de 1 (um) o valor dessa variável, mais fragmentada (menor a concentração) é a câmara legislativa do município e quanto mais próximo de 0 (zero), mais concentrado.

$$
\text { frag }=1-\sum_{w=j}^{J} v_{w}^{2}
$$

A variável $v_{w}$ é a proporção de cadeiras ocupadas por cada partido $w$ na câmara legislativa municipal. Com base nos resultados de vários trabalhos empíricos, espera-se um efeito negativo dessa variável no resultado, pois quanto maior o valor do índice, maior será a dispersão das preferências, significando uma maior heterogeneidade das preferências dos eleitores, dificultando a realização de ajustes fiscais (COSSIO, 2001; SAKURAI, 2014; MENEZES, 2005) e, por este motivo, é normalmente tomada como fator de indisciplina fiscal. Indicador de Competitividade no Executivo (ICEx): Este indicador pretende medir se há influência do nível de disputas para cargos de chefe do executivo nas contas públicas subnacionais. O cálculo do indicador é baseado no inverso do índice de concentração de Herfindhal-Hirschman, que identificará o número efetivo de candidatos concorrentes à eleição e, dessa forma, quanto maior o valor de ICEx, maior será a disputa nas eleições:

$$
I C E x=\frac{1}{\sum_{k=1}^{m} p_{k}^{2}}
$$

Nessa expressão, $k=1, \ldots, m$ é a quantidade de candidatos que concorrem à eleição e $p_{k}$ é a porcentagem de votos recebidos por cada candidato $k$. Uma das vantagens desse indicador é que ele leva em consideração o total de candidatos, assim como a força relativa desses caracterizada pela porcentagem de votos. Espera-se um sinal positivo para o coeficiente dessa variável pois, quanto maior a competição política no município, maior é o incentivo gerado ao candidato à reeleição em gerir as contas públicas de forma responsável.

Participação Popular $\left(\boldsymbol{P P}_{i}\right)$ : Este indicador pretende medir se o interesse e a participação dos eleitores possuem algum efeito na execução das políticas fiscais locais. O indicador é construído como a proporção entre os votos válidos e os votos brancos e nulos no município $i$ na eleição municipal imediatamente anterior ao ano $t$. Embora os votos brancos e nulos possam ser interpretados como uma forma de protesto contra o governo, eles podem ser boas proxies para 
o desinteresse político e para a falta de informação a respeito dos candidatos, pelo eleitorado. Dessa forma:

$$
P P_{i t}=Q_{v i} /\left(Q_{b i}+Q_{n i}\right)
$$

$Q_{v i}$ é a quantidade de votos válidos, $Q_{b i}$ é a quantidade de votos brancos e $Q_{n i}$ é a quantidade de votos nulos no município $i$ na eleição imediatamente anterior ao tempo $t$. Esperase um efeito positivo no resultado fiscal, indicando que a participação popular no processo eleitoral atua como um mecanismo disciplinador na gerência das contas dos entes públicos.

Ideologia Partidária (Ideol): Este indicador é construído com base no trabalho de Zucco e Powell (2009). Esse trabalho estimou as posições ideológicas dos partidos políticos brasileiros a partir de questionários aplicados aos legisladores federais de 1990 a 2013. As posições ideológicas são dispostas em um intervalo 0 (zero) e 1 (um) em que zero corresponde a extrema esquerda e um a extrema direita.

\subsubsection{Características dos candidatos}

Este conjunto de variáveis visa capturar o efeito das características pessoais do prefeito do município diante das decisões tomadas na política fiscal. O conjunto consiste das variáveis sexo, escolaridade e idade do prefeito. Essas variáveis foram coletadas junto ao Tribunal Superior Eleitoral para os pleitos de 2000, 2004, 2008 e 2012.

Sexo do Prefeito (Sexo): O sexo do prefeito. Variável dummy que receberá o valor 1 (um) caso o prefeito seja do sexo masculino e 0 (zero) caso contrário.

Instrução do Prefeito (Escolaridade): Grau de escolaridade do prefeito do município $i$. Variável discreta, construída com os anos de estudo dos prefeitos de cada município. Espera-se um sinal positivo pois, teoricamente, gestores com mais tempo de estudo estão mais aptos a lidar com questões mais complexas como a política fiscal.

Idade do Prefeito (Idade): Possivelmente, maior idade está associada a maior experiência, o que poderia indicar melhor condução da política fiscal e, portanto, um sinal positivo no coeficiente; no entanto, não há, a priori, expectativa definida. 


\subsubsection{Aspectos socioeconômicos}

As variáveis de controle visam capturar o impacto das características socioeconômicas e demográficas de cada município nos resultados fiscais. Os dados foram coletados no domínio do Instituto Brasileiro de Geografia e Estatística (IBGE):

Taxa de pobreza: Taxa de pobreza municipal. Indicador construído com a interpolação linear de dados do censo populacional do IBGE. Espera-se um efeito negativo no indicador de resultado primário já que é de se esperar que estados com população mais pobre tenham um nível menor de receita.

Índice de Gini: Esse indicador mede a desigualdade de renda familiar. Ele foi construído com a interpolação linear de dados do IBGE em que os dados são distribuídos em um intervalo de 0 (zero) a 1 (um) em que quanto mais próximos a 1 (um) pior é a desigualdade na localidade. Dessa forma, espera-se um efeito negativo no indicador de resultado primário.

Taxa de analfabetismo: Indicador construído com a interpolação linear de dados do censo populacional do IBGE. Esta variável é utilizada como proxy do grau de transparência política dos municípios.

População: Este indicador corresponde à estimativa da população por município construída pelo IBGE. Ele pretende capturar o efeito do tamanho da cidade uma vez que, teoricamente, grandes cidades, por apresentarem problemas mais complexos do que pequenas cidades, necessitam de investimentos públicos mais vultuosos e dessa forma, espera-se um efeito negativo no coeficiente.

A Tabela 1.3 apresenta a descrição, algumas estatísticas descritivas e o sinal esperado das variáveis de controle utilizadas nos trabalhos econométricos. 
Tabela 1.3 - Descrição, estatísticas descritivas e efeito esperado das variáveis de interesse e de controle

\begin{tabular}{|c|c|c|c|c|c|c|}
\hline Variáveis & Descrição das Variáveis & Média & $\begin{array}{r}\text { Desvio } \\
\text { Padrão }\end{array}$ & Min & Max & $\operatorname{Sinal}_{1}^{\prime}$ \\
\hline ICEx & $\begin{array}{l}\text { Indicador de competitividade no Executivo local - mede o } \\
\text { quanto as disputas para cargos de chefe do Executivo são } \\
\text { acirradas em nível municipal. }\end{array}$ & 2,22 & 0,67 & 1,00 & 10,42 & + \\
\hline Frag. & $\begin{array}{l}\text { Indicador de fragmentação no Legislativo local - representa } \\
\text { a fragmentação da câmara legislativa municipal e indicará } \\
\text { a influência da coesão/dispersão das preferências dos } \\
\text { partidos políticos sobre o desempenho fiscal. }\end{array}$ & 0,74 & 0,10 & 0,00 & 0,94 & - \\
\hline PPi & $\begin{array}{l}\text { Participação popular - proxies para o desinteresse político e } \\
\text { para a falta de informação a respeito dos candidatos, pelo } \\
\text { eleitorado. O indicador pretende medir se o interesse e a } \\
\text { participação dos eleitores possuem algum efeito na } \\
\text { execução das políticas fiscais locais. }\end{array}$ & 81,89 & 8,70 & 9,16 & 98,14 & + \\
\hline Ideologia & Ideologia partidária - posição ideológica dos partidos. & 5,04 & 1,21 & 2,13 & 6,87 & + \\
\hline Id_Pres & $\begin{array}{l}\text { Identidade ideológica com o presidente - prefeito e } \\
\text { presidente são do mesmo partido }\end{array}$ & 0,10 & 0,29 & 0,00 & 1,00 & + \\
\hline Id_CoaPres & $\begin{array}{l}\text { Identidade ideológica com os partidos da coalizão do } \\
\text { presidente - partido do prefeito pertence à coalizão dos } \\
\text { partidos do presidente. }\end{array}$ & 0,11 & 0,31 & 0,00 & 1,00 & + \\
\hline Id_Gov & $\begin{array}{l}\text { Identidade ideológica com o partido do governador - } \\
\text { partido do prefeito e o partido do governador são o mesmo. }\end{array}$ & 0,20 & 0,40 & 0,00 & 1,00 & + \\
\hline Id_CoaGov & $\begin{array}{l}\text { Identidade ideológica com os partidos da coalizão do } \\
\text { governador - partido do prefeito pertence à coalizão dos } \\
\text { partidos do governador do estado. }\end{array}$ & 0,16 & 0,37 & 0,00 & 1,00 & + \\
\hline Idade & Idade do prefeito & 48,49 & 9,71 & 0,00 & 88,00 & + \\
\hline Escola & Escolaridade do prefeito em anos de estudo & 4,65 & 1,72 & 1,00 & 7,00 & + \\
\hline Sexo & $\begin{array}{l}\text { Dummy que recebe } 1 \text { (um) caso o prefeito seja do sexo } \\
\text { masculino e } 0 \text { (zero) caso contrário }\end{array}$ & 0,92 & 0,28 & 0,00 & 1,00 & $?$ \\
\hline Analf & Taxa de analfabetismo & 18,11 & 10,94 & 0,75 & 58,23 & - \\
\hline Pobreza & Indicador de pobreza & 29,42 & 20,48 & $-10,8$ & 88,65 & - \\
\hline Mort & Taxa de mortalidade & 24,46 & 11,45 & 5,71 & 96,37 & - \\
\hline
\end{tabular}

Fonte: Elaborado pela autora.

Nota: $/^{1}$ : Os sinais são referentes a equação do teste 1 .

Sinal convencional utilizado: + se sinal esperado será positivo, - se sinal esperado for negativo e ? se nenhum sinal for esperado.

\subsection{Resultados}

Nesta seção são apresentadas as estimativas para o impacto nos indicadores de sustentabilidade físcal. Optou-se pela apresentação desses resultados em subseções distintas para cada uma das estratégias de estimação adotadas: dados em painel clássico e o modelo de diferenças em diferenças. 


\subsubsection{Resultados da metodologia tradicional de dados em painel ${ }^{1}$}

A utilização da abordagem de dados em painel possui várias vantagens e uma das principais é que ela controla o problema de viés por variável omitida invariantes no tempo sob forma de efeitos individuais. Por exemplo, considere o crescimento das despesas públicas nos municípios do Brasil. É fato que cada localidade possui características específicas que influenciam a forma como os governantes lidam com o problema do aumento de gastos públicos, tais como as instituições locais, a existência ou não de uma população tradicionalmente atuante na política, a região a que pertence. Estes fatores afetam a variável despesa pública, mas não podem ser mensurados e a omissão destes pode viesar os resultados encontrados.

No entanto, os modelos de dados em painel não estão isentos de problemas, os quais incluem o viés de variável omitida variante no tempo. Um exemplo do problema de variável omitida invariante no tempo é a habilidade e a experiência do prefeito e de sua equipe na resolução de problemas de ordem fiscal. Estes problemas não poderão ser identificados pelos métodos tradicionais de dados em painel. Na seção 4.3 propomos um método para tratar parte desse problema.

As análises desta seção utilizam o modelo de painel com efeitos fixos com erro padrão robustos à heterocedasticidade descrito abaixo:

$$
\begin{gathered}
\text { Fiscal }_{i t}=\alpha_{i}+\beta_{1} \cdot G 1_{i t}+\beta_{2} \cdot G 2_{i t}+\gamma \cdot \text { Pessoais }_{i t}+\delta \cdot \text { Outras Políticas }_{i t}+ \\
\mu \cdot \text { Sociais }_{i t}+c_{i}+\epsilon_{i t}
\end{gathered}
$$

A utilização da técnica de efeitos fixos baseia-se no resultado dos testes de Hausman $^{2} \mathrm{e}$ Chow para todas as variáveis dependentes. O resultado dos testes indica a presença de correlação entre o componente individual (o parâmetro $c_{i}$ da equação acima) e as variáveis explicativas, de forma que o estimador de efeitos fixos é o mais adequado para o modelo. A utilização das estimações considerando erros padrão robustos baseia-se no teste de autocorrelação de Wooldridge $^{3}$ (2002), pelo qual rejeita-se a hipótese nula de ausência de autocorrelação.

A Tabela 1.4 sintetiza os diversos coeficientes obtidos para o teste 1 (Resultado Primário ${ }_{i t}$ ) em quatro contextos distintos: teste 1.1 (sem controles, com dummies

\footnotetext{
${ }^{1}$ Uma análise contendo variáveis de controle sobre controles orçamentários está no ANEXO A.1.

${ }^{2}$ Os resultados para o teste de Hausman está no ANEXO A. Além deste teste, em anexo estão os resultados para o teste de Chow, que visa escolher entre o modelo de efeitos fixos e modelo empilhado.

${ }^{3}$ Os resultados para o teste de autocorrelação de Wooldridge estão no ANEXO A.
} 
de tempo e efeitos fixos); teste 1.2 (com controles de variáveis políticas e efeitos fixos); teste 1.3 (com controles de variáveis políticas e pessoais e efeitos fixos) e teste 1.4 (modelo completo, isto é, com controles de variáveis políticas, pessoais e sociais e efeitos fixos). Estes testes têm o objetivo de medir a importância dos grupos das covariadas para a robustez do modelo.

De acordo com os resultados do teste de hipóteses de igualdade dos coeficientes para o teste 1.4 e relacionados à $\mathrm{G} 1$ e à $\mathrm{G} 2$ temos que $\mathrm{F}(1,5431)=3,10$ e $\mathrm{Prob}>\mathrm{F}=0,0784$ e, então, rejeita a hipótese nula de igualdade dos coeficientes a um nível de $10 \%$.

Tabela 1.4 - Coeficientes obtidos para o modelo 1 de painel com efeitos fixos

\begin{tabular}{|c|c|c|c|c|}
\hline \multirow[b]{2}{*}{ Variáveis } & \multicolumn{4}{|c|}{ Efeitos Fixos } \\
\hline & teste 1.1 & teste 1.2 & teste 1.3 & teste 1.4 \\
\hline \multirow[t]{2}{*}{ G1 } & $0,00108 * * *$ & $0,00114 * * *$ & $0,00125 * * *$ & $0,00124 * * *$ \\
\hline & $(0,00018)$ & $(0,00021)$ & $(0,00021)$ & $(0,00021)$ \\
\hline \multirow[t]{2}{*}{$\mathrm{G} 2$} & $0,00112 * * *$ & $0,00074 * *$ & $0,00077 * *$ & $0,00072 * *$ \\
\hline & $(0,00026)$ & $(0,00031)$ & $(0,00031)$ & $(0,00031)$ \\
\hline Outras Políticas`1 & Não & Sim & Sim & Sim \\
\hline Pessoais ${ }^{12}$ & Não & Não & Sim & Sim \\
\hline Sociais $^{13}$ & Não & Não & Não & Sim \\
\hline $\mathrm{Ano}^{14}$ & Sim & Sim & Sim & Sim \\
\hline \multirow[t]{2}{*}{ Constant } & $1.092 * * *$ & $1.148 * * *$ & $1.137 * * *$ & $1.404 * * *$ \\
\hline & $(0.04460)$ & $(0.05160)$ & $(0.05160)$ & $(0.10400)$ \\
\hline Observações & 63.774 & 51.131 & 51.131 & 50.905 \\
\hline $\mathrm{R}^{2}$ & 0,013 & 0,014 & 0,014 & 0,014 \\
\hline Quant. Municípios & 5.555 & 5.440 & 5.440 & 5.432 \\
\hline
\end{tabular}

Nota: Erro padrão em parênteses. *** $\mathrm{p}<0.01,{ }^{* *} \mathrm{p}<0.05,{ }^{*} \mathrm{p}<0.1$

${ }^{11}$ Variáveis políticas: índice de competitividade política no Executivo, fragmentação do Legislativo, indicador de participação popular e alinhamentos políticos.

${ }^{12}$ Variáveis pessoais: características pessoais do prefeito - idade do prefeito, grau de instrução e sexo.

${ }^{13}$ Variáveis sociais: taxa de analfabetismo, taxa de população economicamente ativa e mortalidade.

${ }^{14}$ Ano: tendência anual.

O teste 1.1 aponta para a existência de um efeito estatisticamente significativo e muito próximo nos dois grupos de prefeitos. Os prefeitos pertencentes à G1 têm em média um aumento de $0,108 \%$ na razão resultado primário sobre Produto Interno Bruto municipal, enquanto prefeitos pertencentes à $\mathrm{G} 2$ têm em média um aumento de $0,112 \%$ nessa mesma razão. Quando se adicionam as variáveis de controle (teste 1.2), as quais também contribuem para explicar o indicador de sustentabilidade fiscal utilizado, os coeficientes continuam significativos, mas G1 demonstra um leve crescimento de $0,06 \%$ no coeficiente, chegando a 0,114\%; o coeficiente para G2 indica uma queda no seu efeito. Nota-se que a inclusão dos outros grupos de variáveis de controle mantém a significância dos coeficientes e não apresentam uma alteração considerável, sugerindo que o conjunto de controles utilizado possui o potencial de captar razoavelmente bem a heterogeneidade dos entes da amostra, promovendo adequado tratamento ao problema de simultaneidade e indicando a robustez do modelo. 
Tabela 1.5 - Resultados do modelo de efeitos fixos robustos

\begin{tabular}{|c|c|c|c|c|c|c|c|c|}
\hline Variáveis & $\begin{array}{c}\text { Teste } 1 \\
\text { Resultado } \\
\text { Primário } \\
\end{array}$ & $\begin{array}{c}\text { Teste } 2 \\
\text { Receita } \\
\text { Primária } \\
\end{array}$ & $\begin{array}{c}\text { Teste } 3 \\
\text { Arrecadação }\end{array}$ & $\begin{array}{c}\text { Teste } 4 \\
\text { Transf. } \\
\text { Voluntárias }\end{array}$ & $\begin{array}{c}\text { Teste } 5 \\
\text { Despesas } \\
\text { Primárias } \\
\end{array}$ & $\begin{array}{c}\text { Teste } 6 \\
\text { Despesa com } \\
\text { Pessoal } \\
\end{array}$ & $\begin{array}{c}\text { Teste } 7 \\
\text { Gasto com } \\
\text { Investimento }\end{array}$ & $\begin{array}{c}\text { Teste } 8 \\
\text { Gasto } \\
\text { Social } \\
\end{array}$ \\
\hline G1 & $\begin{array}{c}0,00123 * * * \\
(0,000208)\end{array}$ & $\begin{array}{c}0,000675 \\
(0,000586)\end{array}$ & $\begin{array}{c}-0,000162 \\
(0,000331)\end{array}$ & $\begin{array}{c}0,00128^{* * * *} \\
(0,000208)\end{array}$ & $\begin{array}{l}-0,000556 \\
(0,000592)\end{array}$ & $\begin{array}{c}0,000598^{* * *} \\
(0,000299)\end{array}$ & $\begin{array}{c}-0,00201 * * * \\
(0,000268)\end{array}$ & $\begin{array}{c}0,00146 * * * \\
(0,000531)\end{array}$ \\
\hline G2 & $\begin{array}{c}0,000711^{* *} \\
(0,000307)\end{array}$ & $\begin{array}{c}-0,00307 * * * * \\
(0,000949)\end{array}$ & $\begin{array}{c}-0,000681 \\
(0,000552)\end{array}$ & $\begin{array}{c}-0,00133 * * * \\
(0,000293)\end{array}$ & $\begin{array}{c}-0,00378 * * * \\
(0,000973)\end{array}$ & $\begin{array}{c}0,000975 * * \\
(0,000481)\end{array}$ & $\begin{array}{c}-0,00492 * * * \\
(0,000436)\end{array}$ & $\begin{array}{c}0,00111 \\
(0,000786)\end{array}$ \\
\hline ICEx & $\begin{array}{c}0,000558^{* * *} * \\
(0,000159)\end{array}$ & $\begin{array}{c}0,000261 \\
(0,000510)\end{array}$ & $\begin{array}{c}-0,000210 \\
(0,000233)\end{array}$ & $\begin{array}{c}-0,000361 * * * \\
(0,000133)\end{array}$ & $\begin{array}{c}-0,000296 \\
(0,000533)\end{array}$ & $\begin{array}{c}0,000124 \\
(0,000281)\end{array}$ & $\begin{array}{c}-0,000677 \text { *** } \\
(0,000208)\end{array}$ & $\begin{array}{c}0,000456 \\
(0,000413)\end{array}$ \\
\hline Frag. & $\begin{array}{c}0,00192 \\
(0,00182)\end{array}$ & $\begin{array}{l}0,00191 \\
(0,0121)\end{array}$ & $\begin{array}{l}-0,00285 \\
(0,00239)\end{array}$ & $\begin{array}{c}0,00259 \\
(0,00206)\end{array}$ & $\begin{array}{l}2,40 \mathrm{e}-05 \\
(0,0122)\end{array}$ & $\begin{array}{l}0,0105 * * \\
(0,00511)\end{array}$ & $\begin{array}{c}-0,00894 * * * \\
(0,00302)\end{array}$ & $\begin{array}{c}0,0366 * * * \\
(0,00708)\end{array}$ \\
\hline Partic, Pop & $\begin{array}{c}8,04 \mathrm{e}-06 \\
(1,70 \mathrm{e}-05)\end{array}$ & $\begin{array}{l}-4,25 \mathrm{e}-05 \\
(8,23 \mathrm{e}-05)\end{array}$ & $\begin{array}{l}-3,88 \mathrm{e}-05^{*} \\
(2,00 \mathrm{e}-05)\end{array}$ & $\begin{array}{c}4,02 \mathrm{e}-05 * * \\
(1,60 \mathrm{e}-05)\end{array}$ & $\begin{array}{l}-5,08 \mathrm{e}-05 \\
(8,33 \mathrm{e}-05)\end{array}$ & $\begin{array}{c}-9,32 \mathrm{e}-05 * * \\
(3,81 \mathrm{e}-05)\end{array}$ & $\begin{array}{l}-1,64 \mathrm{e}-05 \\
(2,16 \mathrm{e}-05)\end{array}$ & $\begin{array}{c}0,000138 * * * \\
(5,21 \mathrm{e}-05)\end{array}$ \\
\hline Ideologia & $\begin{array}{c}-7,17 \mathrm{e}-06 \\
(0,000112)\end{array}$ & $\begin{array}{c}0,00166^{* * * *} \\
(0,000313)\end{array}$ & $\begin{array}{c}0,000167 \\
(0,000151)\end{array}$ & $\begin{array}{c}-0,000314 * * * \\
(0,000109)\end{array}$ & $\begin{array}{c}0,00166 * * * \\
(0,000326)\end{array}$ & $\begin{array}{l}-3,94 \mathrm{e}-05 \\
(0,000165)\end{array}$ & $\begin{array}{c}0,000878^{* * *} * \\
(0,000145)\end{array}$ & $\begin{array}{c}0,00101 * * * \\
(0,000274)\end{array}$ \\
\hline Pref e Pres & $\begin{array}{c}0,000486 \\
(0,000388)\end{array}$ & $\begin{array}{l}0,0157 * * \\
(0,00787)\end{array}$ & $\begin{array}{l}0,00115^{* *} \\
(0,000574)\end{array}$ & $\begin{array}{c}0,00273 * * * \\
(0,000355)\end{array}$ & $\begin{array}{c}0,0152^{*} \\
(0,00792)\end{array}$ & $\begin{array}{c}0,00725^{* *} \\
(0,00324)\end{array}$ & $\begin{array}{c}0,00450 \text { *** } \\
(0,00104)\end{array}$ & $\begin{array}{c}0,0195 * * * \\
(0,00389)\end{array}$ \\
\hline Pref e Gov & $\begin{array}{c}8,74 \mathrm{e}-05 \\
(0,000248)\end{array}$ & $\begin{array}{c}0,000672 \\
(0,000617)\end{array}$ & $\begin{array}{l}-0,000155 \\
(0,000311)\end{array}$ & $\begin{array}{c}-0,000676 * * * \\
(0,000203)\end{array}$ & $\begin{array}{c}0,000585 \\
(0,000627)\end{array}$ & $\begin{array}{c}-9,56 \mathrm{e}-06 \\
(0,000329)\end{array}$ & $\begin{array}{l}-0,000315 \\
(0,000281)\end{array}$ & $\begin{array}{c}0,00191 * * * \\
(0,000613)\end{array}$ \\
\hline Pref e Coa Gov & $\begin{array}{c}-0,000184 \\
(0,000331)\end{array}$ & $\begin{array}{c}0,00782 \\
(0,00666)\end{array}$ & $\begin{array}{c}7,01 \mathrm{e}-05 \\
(0,000570)\end{array}$ & $\begin{array}{c}0,000294 \\
(0,000396)\end{array}$ & $\begin{array}{c}0,00803 \\
(0,00673)\end{array}$ & $\begin{array}{c}0,00433 \\
(0,00272)\end{array}$ & $\begin{array}{c}0,00166^{*} \\
(0,000960)\end{array}$ & $\begin{array}{c}0,00725 * * \\
(0,00322)\end{array}$ \\
\hline Pref e Coa Pres & $\begin{array}{c}-0,000386 \\
(0,000366)\end{array}$ & $\begin{array}{c}0,00999 * * * \\
(0,00143)\end{array}$ & $\begin{array}{l}0,00106 * * \\
(0,000424)\end{array}$ & $\begin{array}{c}-0,00325 * * * * \\
(0,000350)\end{array}$ & $\begin{array}{c}0,0104 * * * \\
(0,00145)\end{array}$ & $\begin{array}{c}0,00622 * * * \\
(0,000658)\end{array}$ & $\begin{array}{c}0,00330 * * * \\
(0,000456)\end{array}$ & $\begin{array}{c}0,00929 * * * \\
(0,000899)\end{array}$ \\
\hline Idade & $\begin{array}{c}5,32 \mathrm{e}-05 * * * \\
(1,94 \mathrm{e}-05)\end{array}$ & $\begin{array}{l}-6,55 \mathrm{e}-05 \\
(6,06 \mathrm{e}-05)\end{array}$ & $\begin{array}{l}-4,90 \mathrm{e}-05 \\
(3,72 \mathrm{e}-05)\end{array}$ & $\begin{array}{c}-3,91 \mathrm{e}-05^{* *} \\
(1,63 \mathrm{e}-05)\end{array}$ & $\begin{array}{c}-0,000119^{*} \\
(6,39 \mathrm{e}-05)\end{array}$ & $\begin{array}{c}1,59 \mathrm{e}-05 \\
(3,14 \mathrm{e}-05)\end{array}$ & $\begin{array}{c}-5,37 \mathrm{e}-05^{* *} \\
(2,21 \mathrm{e}-05)\end{array}$ & $\begin{array}{l}-2,51 \mathrm{e}-05 \\
(4,36 \mathrm{e}-05)\end{array}$ \\
\hline Escola & $\begin{array}{l}-0,000132 \\
(0,000104)\end{array}$ & $\begin{array}{l}-0,000131 \\
(0,000341)\end{array}$ & $\begin{array}{c}-0,000134 \\
(0,000149)\end{array}$ & $\begin{array}{c}0,000352 * * * \\
(0,000102)\end{array}$ & $\begin{array}{c}2,03 \mathrm{e}-07 \\
(0,000354)\end{array}$ & $\begin{array}{c}-0,000131 \\
(0,000179)\end{array}$ & $\begin{array}{c}0,000347^{* *} * \\
(0,000135)\end{array}$ & $\begin{array}{c}0,000272 \\
(0,000243)\end{array}$ \\
\hline Sexo & $\begin{array}{c}0,000541 \\
(0,000656)\end{array}$ & $\begin{array}{c}-0,0121 \\
(0,00994)\end{array}$ & $\begin{array}{l}0,000378 \\
(0,00101)\end{array}$ & $\begin{array}{c}-0,000325 \\
(0,000587)\end{array}$ & $\begin{array}{l}-0,0127 \\
(0,0100)\end{array}$ & $\begin{array}{l}-0,00574 \\
(0,00405)\end{array}$ & $\begin{array}{l}-0,00118 \\
(0,00147)\end{array}$ & $\begin{array}{l}-0,00732 \\
(0,00485)\end{array}$ \\
\hline Analf. & $\begin{array}{l}-8,62 \mathrm{e}-05 \\
(0,000106)\end{array}$ & $\begin{array}{l}-0,00131 * * \\
(0,000547)\end{array}$ & $\begin{array}{l}-0,000185 \\
(0,000158)\end{array}$ & $\begin{array}{c}0,000572 * * * \\
(0,000116)\end{array}$ & $\begin{array}{l}-0,00122 * * \\
(0,000558)\end{array}$ & $\begin{array}{c}-0,00153 * * * \\
(0,000265)\end{array}$ & $\begin{array}{c}0,000568^{* * * *} \\
(0,000181)\end{array}$ & $\begin{array}{c}-0,00258^{* * * *} \\
(0,000348)\end{array}$ \\
\hline Mort & $\begin{array}{l}-4,30 \mathrm{e}-05 \\
(3,53 \mathrm{e}-05)\end{array}$ & $\begin{array}{l}-0,000516 \\
(0,000436)\end{array}$ & $\begin{array}{c}-0,000173 * * * \\
(5,71 \mathrm{e}-05)\end{array}$ & $\begin{array}{c}0,000233 * * * \\
(3,98 \mathrm{e}-05)\end{array}$ & $\begin{array}{c}-0,000471 \\
(0,000439)\end{array}$ & $\begin{array}{c}-0,000712 * * * \\
(0,000182)\end{array}$ & $\begin{array}{l}0,000148^{*} \\
(7,59 \mathrm{e}-05)\end{array}$ & $\begin{array}{c}-0,000986 * * * \\
(0,000219)\end{array}$ \\
\hline Gini & $\begin{array}{l}-0,00178 \\
(0,00250)\end{array}$ & $\begin{array}{c}-0,000389 \\
(0,0234)\end{array}$ & $\begin{array}{c}-0,00250 \\
(0,00376)\end{array}$ & $\begin{array}{c}-0,0139 \text { *** } \\
(0,00219)\end{array}$ & $\begin{array}{l}0,00147 \\
(0,0237)\end{array}$ & $\begin{array}{c}0,0150 \\
(0,00976)\end{array}$ & $\begin{array}{c}-0,0157 \text { *** } \\
(0,00450)\end{array}$ & $\begin{array}{c}-0,0687 * * * \\
(0,0124)\end{array}$ \\
\hline Pop & $\begin{array}{l}3,74 \mathrm{e}-08 * * \\
(1,48 \mathrm{e}-08)\end{array}$ & $\begin{array}{c}-1,28 \mathrm{e}- \\
07 * * * \\
(4,37 \mathrm{e}-08)\end{array}$ & $2,80 \mathrm{e}-08$ & $2,00 \mathrm{e}-09$ & $\begin{array}{c}-1,65 \mathrm{e}- \\
07 * * * \\
(5,21 \mathrm{e}-08)\end{array}$ & $-1,27 \mathrm{e}-07 * * *$ & $-5,56 \mathrm{e}-08^{* * * *}$ & $-1,55 \mathrm{e}-07 * * *$ \\
\hline Constant & $\begin{array}{c}1,369 * * * \\
(0,108)\end{array}$ & $\begin{array}{c}-2,173 \text { *** } \\
(1,025)\end{array}$ & $\begin{array}{c}0,00177 \\
(0,232)\end{array}$ & $\begin{array}{c}-0,824 * * * * \\
(0,0949)\end{array}$ & $\begin{array}{c}-3,545^{* * *} \\
(1,037)\end{array}$ & $\begin{array}{l}-0,540 \\
(0,431)\end{array}$ & $\begin{array}{c}-1,460 \text { **** } \\
(0,198)\end{array}$ & $\begin{array}{c}-0,780 \\
(0,529)\end{array}$ \\
\hline $\begin{array}{l}\text { Ano } \\
\mathrm{R}^{2}\end{array}$ & $\begin{array}{c}\text { Sim } \\
0,014\end{array}$ & $\begin{array}{c}\text { Sim } \\
0,009\end{array}$ & $\begin{array}{c}\text { Sim } \\
0,009\end{array}$ & $\begin{array}{c}\text { Sim } \\
0,021\end{array}$ & $\begin{array}{c}\text { Sim } \\
0,012\end{array}$ & $\begin{array}{c}\mathrm{Sim} \\
0,032\end{array}$ & $\begin{array}{c}\text { Sim } \\
0,016\end{array}$ & $\begin{array}{c}\text { Sim } \\
0,055\end{array}$ \\
\hline
\end{tabular}

Fonte. Tabela elaborada pela autora.

Nota: Erro padrão entre parênteses. $* p<0.10 ; * * p<0.05$; *** $p<0.01$.

A Tabela 1.5 apresenta os resultados utilizando-se todas as variáveis de controle descritas para as oito variáveis dependentes. Os resultados indicam que os municípios em que os prefeitos são de primeiro mandato tendem a apresentar um efeito positivo no resultado primário, ou seja, um prefeito que se candidata à reeleição gera em média um superávit primário de $0,11 \%$ em porcentagem do Produto Interno Bruto (PIB) municipal maior do que um prefeito de segundo mandato. Interessante também notar que prefeitos do grupo G1 possuem um efeito mais forte do que seus pares em G2 com 0,07\% do PIB municipal. Desse modo, pode-se inferir dos resultados que prefeitos com expectativas de reeleição apresentam uma política fiscal mais sustentável com a geração de receitas em volume suficiente para cobrir as despesas sem comprometer sua capacidade de administrar a dívida existente. Esse resultado está de acordo com Meneguin, Bugarin e Carvalho (2005) que concluíram que quando há possibilidade de reeleição, o prefeito é mais responsável com a política fiscal do município, pois ele terá que arcar com o ônus futuro de um endividamento público. 
Os municípios regidos por prefeitos em primeiro mandato com expectativas de reeleição tendem a receber mais recursos via convênios públicos - um aumento de em média $0,128 \%$ em relação ao Produto Interno Bruto (PIB) municipal. Ao contrário, os prefeitos em G2 apresentaram um decréscimo de em média $0,13 \%$ do PIB municipal. Uma das explicações possíveis é que a expectativa de reeleição também pode afetar o jogo político nos níveis superiores do governo, que transferem mais recursos, de forma voluntária, a esses políticos em busca de apoio futuro.

No que se refere aos gastos, os prefeitos pertencentes à G1 apresentam um aumento de em média $0,059 \%$ no PIB municipal com folha de pagamento de funcionários públicos e uma redução no gasto com investimentos de capital. Esse mesmo efeito é observado nos prefeitos pertencentes à G2, mas com maior intensidade. Este resultado pode sugerir que candidatos à reeleição em média são mais cuidadosos com os gastos rígidos e difíceis de serem reduzidos no curto prazo do que seus pares de primeiro mandato e sem expectativa de reeleição; afinal, no próximo mandato, ele terá que arcar com possíveis endividamentos e com a dificuldade em promover cortes orçamentários em um orçamento todo comprometido com despesas fixas (MENEGUIN \& BUGARIN, 2001).

A equação referente aos gastos sociais (teste 8) apresenta um efeito positivo e bastante significativo para os prefeitos de G1. Nota-se um aumento de em média 0,14\% do PIB municipal com gasto em educação, cultura, saneamento e saúde. A melhora nos indicadores sociais é apontada como um fator determinante de sucesso em uma reeleição (MENEZES, SAIANI \& ZOGHBI, 2008); então, prefeitos candidatos, para mostrar sua competência, tenderiam a aumentar gastos com políticas sociais de governo. Esse resultado também foi encontrado por Novaes e Mattos (2010), o quais testam a hipótese de que com a elevação dos gastos em saúde o governante estará demonstrando esforço para prover bens públicos aos eleitores e, assim, construir uma reputação que aumente suas chances de se reeleger.

No que diz respeito ao conjunto de variáveis com características políticas, verificou-se um resultado bastante significativo no nível de competitividade do Executivo local para as equações dos testes 1, 4 e 7, indicando que quanto maior a competitividade nas eleições para prefeitos, no pleito imediatamente anterior ao ano analisado, maior é a medida de resultado primário e menores são as transferências voluntárias de receitas e o investimento de capital. Uma possível explicação para esse resultado é que o fato de uma eleição ser bastante disputada aumenta o incentivo à sustentabilidade fiscal e o que pode afetar diretamente os gastos com investimento (o que explicaria o seu decrescimento). A relação entre os altos níveis de competitividade e a influência negativa nas transferências voluntárias de recursos públicos pode 
ser explicada a luz do modelo dos core-voters (COX \& MCCUBBINS, 1986): a melhor estratégia para os partidos, na tentativa de maximizar votos, seria aplicar seus recursos escassos em seus eleitores fiéis e apoiadores (core-voters) do que aplicar no eleitor mediano (swing voter).

Em geral, a dispersão parlamentar pode gerar maior disputa por recursos e, por este motivo, é normalmente vista como fator de indisciplina fiscal. No entanto, não houve um resultado significativo para esse coeficiente na equação referente ao resultado primário. Mas, pode-se inferir dos resultados que uma maior fragmentação no parlamento municipal induz a um aumento do gasto com pessoal e uma diminuição dos gastos com investimento de capital, o que poderia ser visto como um fator de indisciplina fiscal. No que se refere aos gastos sociais, os resultados indicam que o aumento da fragmentação leva a um aumento desses gastos. Esse fato pode ser explicado ao considerarmos que uma maior dispersão partidária dificulta o processo de negociação do orçamento, o que incentiva a ocorrência de barganha e essa prática incentiva o aumento das despesas em geral, em particular gastos sociais, que são vistas como determinantes para fins de reeleição.

Um resultado interessante é o coeficiente da variável participação popular, o qual se apresenta positivo e bastante significativo para a equação referente aos gastos sociais. Dessa forma, uma participação mais ativa e atuante da sociedade em assuntos políticos do município pode influenciar o montante gasto pelo governo com políticas públicas. Esses gastos sociais podem ser imediatamente sentidos pelo eleitor mais atento e o político tende a aumentar esses gastos para aumentar sua visibilidade política. Esse resultado está de acordo com o trabalho de Schneider, Athias e Bugarin (2016) em que mostram que com a introdução da urna eletrônica, e o consequente aumento da participação dos cidadãos mais pobres no sufrágio eleitoral, houve uma mudança no equilíbrio eleitoral e, com isso, houve um aumento nos gastos sociais, visto que esses cidadãos são os mais beneficiados com os gastos com saúde e educação.

A ideologia do partido dos prefeitos no poder apresenta resultado significativo nas equações dos testes 2, 4, 5, 7 e 8. Quanto mais ideologicamente de direita são os políticos, maiores são as receitas primárias e as despesas primárias. Nota-se que a equação referente à arrecadação (teste 3) não apresentou significância estatística, no entanto na equação referente às transferências voluntárias ela é bastante significativa e tem um sinal negativo, o que significa que municípios governados por partidos mais à direta receberam em média menos transferências voluntárias da União, no intervalo de 2001 a 2012. Como na maioria dos anos dessa análise o país foi governado por um partido de esquerda, podemos explicar esse resultado ao fazermos uma analogia aos resultados de alinhamento partidário. 
As variáveis referentes aos alinhamentos políticos entre os níveis de governo mostram que os prefeitos alinhados ao partido do presidente da República apresentam um efeito positivo em todas as equações referentes às receitas e referentes às despesas. Dessa forma, pode-se inferir que prefeitos alinhados politicamente com o Executivo federal tendem a apresentar maiores gastos por esperarem receber mais recursos em função do alinhamento partidário. E possuem maiores receitas de transferências voluntárias reforçando os resultados dos trabalhos de Bugarin e Marciniuk (2016).

Do conjunto de variáveis que apresentam as características particulares dos prefeitos, é interessante o resultado sobre a variável idade, que é estatisticamente significativa e apresenta um sinal positivo no resultado primário, sugerindo que prefeitos com mais idade são, em média, mais prudentes com o controle das contas municipais.

Com relação ao grupo das características municipais e temporais, a variável analfabetismo apresenta resultados bastante interessantes. Nota-se que quanto maior é a taxa de analfabetismo, mais negativos são os efeitos nas despesas primárias e nas receitas primárias. Interessante notar que quanto maiores são as taxas de analfabetismo maiores são as transferências voluntárias e menores são os gastos sociais com saúde, educação, saneamento básico e cultura.

\subsubsection{Resultados do método das diferenças em diferenças entre quantis com covariadas}

Nesta seção estimamos o efeito dos incentivos eleitorais para os municípios cujos prefeitos são de primeiro mandato sobre a sustentabilidade fiscal dos municípios brasileiros, utilizando-se o método das diferenças em diferenças entre quantis. A utilização desse método objetiva eliminar alguns problemas de viés por variáveis omitidas não eliminadas com a aplicação dos modelos de painel clássicos, além de analisarmos o efeito dos incentivos eleitorais nos diferentes quantis das distribuições de indicadores de políticas fiscais.

O problema de endogeneidade que se pretende eliminar com esta estratégia empírica é a habilidade política nata do candidato. Esta é uma variável omitida ao modelo e que pode viesar os resultados fiscais, favorecendo os municípios com prefeitos de segundo mandato ao compararmos com os prefeitos de primeiro mandato. Entre todos os eleitos, o subconjunto dos prefeitos de segundo mandato pode ser considerado um grupo seleto de governantes, pois estes já passaram por uma aprovação do eleitorado (com a reeleição) ao revelaram sua habilidade política (BASTOS, 2015). 
A construção dos grupos de municípios comparáveis - grupo de tratamento e grupo de controle - e a estratégia de identificação desses grupos é baseada no trabalho de Ferraz e Finan (2010). Os autores propõem a comparação dos municípios com prefeitos de segundo mandato com os municípios com prefeitos de primeiro que serão reeleitos na eleição subsequente. Esta estratégia pretende eliminar os prefeitos de primeiro mandato que possuem uma alta probabilidade de não possuírem boa habilidade política.

O tratamento é a eleição municipal de 2004. Os grupos são construídos da seguinte forma: primeiramente, selecionam-se os prefeitos de primeiro mandato e que tentarão a reeleição em 2004. Após a eleição (tratamento), esse mesmo grupo se dividirá em outros dois grupos distintos entre si: os prefeitos que conseguiram se reeleger e agora se tornaram prefeitos de segundo mandato e os prefeitos que não conseguiram se reeleger e deram lugar a um novo prefeito (prefeito de primeiro mandato). Além disso, para efetivamente retirar o viés de habilidade, esses novos prefeitos de primeiro mandato (legislatura de 2005 a 2008) deverão vencer as eleições subsequentes (eleições de 2012). A Figura 1.3 apresenta o esquema para a estratégia de identificação utilizada.

Figura 1.3 - Estratégia de identificação dos grupos de tratamento e controle

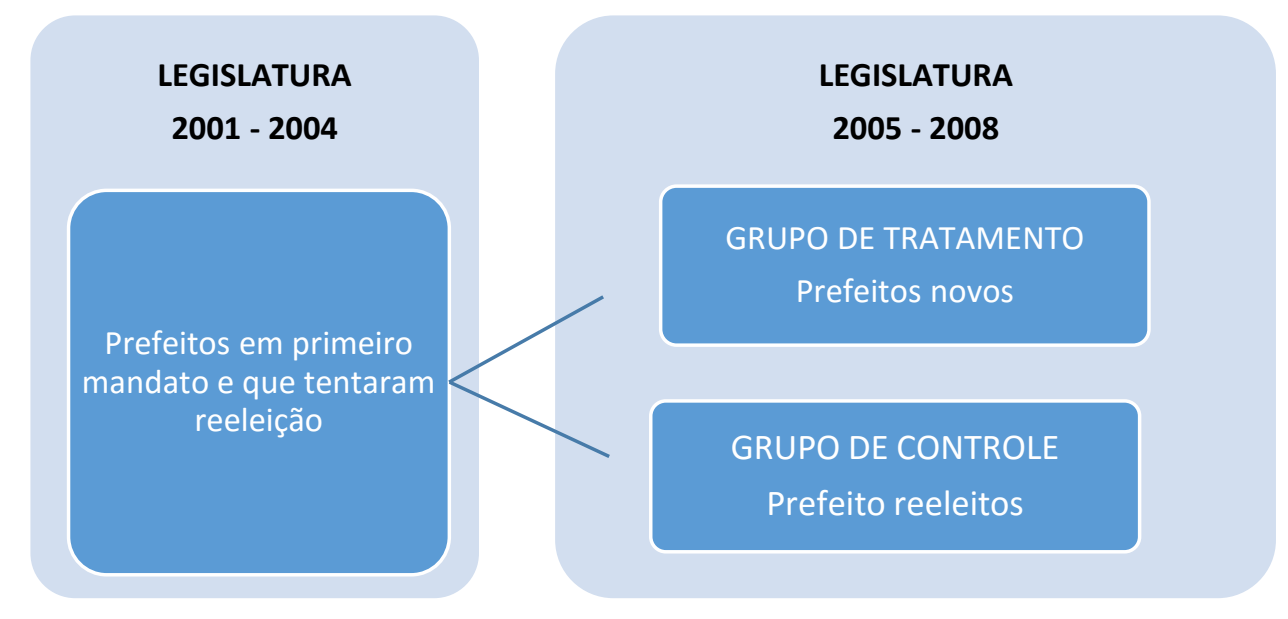

Fonte: Elaborado pela autora.

De acordo com esse método, o impacto da reeleição na política fiscal subnacional será calculado pela comparação da mudança dos resultados fiscais nos municípios do grupo de tratamento com a mudança dos resultados fiscais dos municípios do grupo de controle. Os mesmos municípios são observados nos dois períodos, 2004 e 2008 e, a distribuição do resultado do grupo de controle será subtraído da distribuição dos resultados do grupo de 
tratamento para se chegar ao efeito do tratamento. Assim, em termos de produtos potenciais, o estimador de diferenças em diferenças será dado por:

$$
\delta^{D D}(\tau)=E\left(R P_{1 i T 1}-R P_{0 i T o} \mid G_{1}=1\right)-E\left(R P_{1 i T 1}-R P_{0 i T o} \mid G_{1}=0\right)
$$

Na equação (8), $\delta^{D D}$ é o efeito médio do resultado primário, $G_{1}$ é a variável binária que assume valor 1 (um) para os municípios $i$ em que o prefeito está no seu primeiro mandato e 0 (zero) para os municípios no grupo de controle.

O valor do resultado primário observado nos municípios é RPit em que $\mathrm{T}_{0}$ é o ano de 2004, período pré-tratamento, e $\mathrm{T}_{1}$ é o ano de 2008, período pós-tratamento.

O método das diferenças em diferenças (DD) pode ser utilizado para retomar o impacto do programa sobre os municípios tratados desde que assegurada a hipótese de identificação, segundo a qual o grupo de tratamento teria, na ausência do tratamento, a mesma trajetória do grupo de controle:

$$
E\left(R P_{o i T 1}-R P_{o i T o} \mid G_{1}=1\right)=E\left(R P_{o i T 1}-R P_{0 i T o} \mid G_{1}=0\right)
$$

Por essa hipótese tem-se que as características não observáveis que afetam a reeleição dos prefeitos são invariantes no tempo, o que garante que eventuais desvios das trajetórias podem ser atribuídos ao tratamento.

A implementação do modelo de diferenças em diferenças quantílica será feita através da estimação do modelo de regressão abaixo:

$$
\begin{aligned}
\text { Fiscal }_{i t}=\alpha_{0} & +\alpha_{1} G 1+\alpha_{2} * T+\alpha_{3} * G 1 * T+\gamma \text { Pessoais }_{i t} \\
& + \text { SOutras Políticas }_{i t}+\mu \text { Sociais }_{i t}+e_{i t}
\end{aligned}
$$

Os dados utilizados para os testes são compostos por 2.006 municípios observados nos anos 2004 e 2008. Desse total, 1.509 municípios venceram as eleições em 2004, portanto pertencem ao grupo de controle; 497 municípios não reelegeram seus prefeitos em 2004, mas reelegeram esses novos governantes em 2012; portanto, pertencem ao grupo de tratamento. A Tabela 1.6 apresenta os testes de média para os dois grupos de prefeitos no que se refere às variáveis de controle. Esse teste é feito no tempo t=2004 e tem o objetivo de verificar se os dois grupos de prefeitos são comparáveis. 
Tabela 1.6 - Diferença de média entre as variáveis de controle dos grupos de tratados e de controle antes do tratamento

\begin{tabular}{lrrrrl}
\hline Variáveis & $\begin{array}{r}\text { Grupo de } \\
\text { controle }\end{array}$ & $\begin{array}{r}\text { Grupo de } \\
\text { tratamento }\end{array}$ & Diff & $|\mathrm{t}|$ & $\operatorname{Pr}(|\mathrm{T}|>|\mathrm{t}|)$ \\
\hline ICEx & 2,191 & 2,324 & 0,132 & 4,600 & $0,000^{* * *}$ \\
Fracional & 0,727 & 0,747 & 0,020 & 3,880 & $0,001^{* * *}$ \\
Part_Pop & 81,125 & 80,203 & $-0,922$ & 2,370 & $0,018^{* *}$ \\
Ideologia & 5,104 & 5,132 & 0,028 & 0,380 & 0,701 \\
Pref e pres & 0,044 & 0,038 & $-0,006$ & 0,590 & 0,556 \\
Pref e gov & 0,186 & 0,167 & $-0,019$ & 0,960 & 0,335 \\
Pref e Coa Gov & 0,094 & 0,125 & 0,031 & 1,960 & $0,050^{* *}$ \\
Idade & 50,328 & 47,227 & $-3,101$ & 6,700 & $0,000^{* * *}$ \\
Escolaridade & 4,523 & 4,678 & 0,155 & 1,720 & $0,085^{*}$ \\
Sexo & 0,943 & 0,928 & $-0,015$ & 1,250 & 0,212 \\
Analfabetismo & 18,865 & 18,461 & $-0,403$ & 0,700 & 0,487 \\
Mortalidade & 27,388 & 27,658 & 0,271 & 0,460 & 0,649 \\
Pop & $2.8 \times 10^{4}$ & $3,1 \times 10^{4}$ & 2836,790 & 0,370 & 0,710 \\
\hline Fonte: Elaborado pela autora & & & &
\end{tabular}

Fonte: Elaborado pela autora.

Pode-se observar que a maioria das características definidoras dos municípios não são significativamente diferentes entre os dois grupos e, dessa forma, pode-se sugerir que os dois grupos, tratados e controle, são comparáveis entre si. Um resultado interessante é o fato de o indicador de competitividade no Executivo ser estatisticamente diferente nos dois grupos de prefeitos e se mostra maior, em média, no grupo de municípios de primeiro mandato. Este resultado pode ser explicado levando-se em consideração a visibilidade do titular do cargo e candidato à reeleição, que dificulta a entrada de outros candidatos na disputa eleitoral (STONECASH, 2008).

$\mathrm{O}$ teste de heterocedasticidade de $\mathrm{Wald}^{4}$ rejeitou a hipótese nula de igualdade de coeficientes entre as regressões para grande parte das variáveis dependentes. Conforme Koenker (2005), os efeitos da heterocedasticidade podem ser minimizados com o uso de modelos quantílicos. Tendo em vista que as variáveis explicativas não influenciam igualmente os diferentes níveis de eficiência técnica, foram estimadas regressões para os seguintes quantis: $10 \%, 25 \%, 50 \%, 75 \%$ e $90 \%$. A Tabela 1.7 contém os resultados para o modelo de diferenças em diferenças para a média (DID) e para o modelo de diferenças em diferenças entre quantis (QDID). Todas as equações mostram apenas o coeficiente referente ao conjunto de prefeitos de primeiro mandato, mas foram controladas pelas covariadas.

\footnotetext{
${ }^{4}$ Resultados estão no anexo A.
} 
As estimativas para o teste 1 sugerem que a expectativa de reeleição tem um efeito positivo no superávit primário dos municípios. Este resultado confirma o resultado encontrado na seção anterior. Além disso, no quantil 0,10 dessa distribuição (os 10\% menos sustentáveis do ponto de vista fiscal), o fato de o prefeito estar em primeiro mandato provoca um aumento de $0,585 \%$ no superávit fiscal em porcentagem do Produto Interno Bruto (PIB) municipal. Esse efeito é praticamente o mesmo encontrado para a equação de diferenças em diferenças para a média $(0,578 \%)$ e, em termos de quantis, só é superado pelos $10 \%$ melhores municípios (quantil 0,9). Dessa forma, as estimativas indicam que o efeito da expectativa de reeleição sobre o resultado primário é bem mais forte nos municípios com maior sustentabilidade fiscal e, em seguida, pelos municípios com menor sustentabilidade fiscal.

Ao considerar a metodologia de diferenças em diferenças para a média (DID), nota-se que a expectativa de reeleição, na média, apresentou um aumento de 1,90\% nas receitas primárias em porcentagem do PIB, assim como um aumento de 1,32\% nas despesas primárias em porcentagem do PIB. Esses resultados reforçam a hipótese de que prefeitos que esperam a reeleição tendem a ter uma política fiscal mais sustentável na qual o aumento das despesas é coberto com o aumento das receitas, resultando em um superávit primário (MENEGUIN \& BUGARIN, 2001).

As equações referentes à arrecadação de tributos e ao recebimento de transferências voluntárias (teste 3 e teste 4, respectivamente) são afetadas pela expectativa de reeleição de uma forma interessante: a expectativa de reeleição possui um efeito significativo (e negativo) apenas nos $10 \%$ de municípios que menos arrecadam da distribuição. Isto sugere que prefeitos candidatos à reeleição de cidades com baixa arrecadação (os 10\% que menos arrecadam em porcentagem do PIB municipal) tendem a arrecadar menos do que os prefeitos em segundo mandato. $\mathrm{O}$ recebimento de transferências voluntárias tem um efeito bastante significativo, positivo e crescente a partir do quantil 0,25. 
Tabela 1.7 - Resultados da metodologia de diferenças em diferenças entre quantis

\begin{tabular}{|c|c|c|c|c|c|c|c|c|}
\hline & \multirow[b]{2}{*}{ Equações } & \multirow{2}{*}{\begin{tabular}{|l} 
DID \\
Média
\end{tabular}} & \multicolumn{6}{|c|}{ QDID } \\
\hline & & & Quantil 0,1 & Quantil 0,25 & Quantil 0,5 & Quantil 0,75 & Quantil 0,9 & $\mathrm{R}^{2}$ \\
\hline Teste1 & $\begin{array}{l}\text { Resultado } \\
\text { Primário }\end{array}$ & $\begin{array}{l}0,0058^{* * * *} \\
(0,00132)\end{array}$ & $\begin{array}{c}0,0059^{* * * *} \\
(0,0019)\end{array}$ & $\begin{array}{c}0,0032 * * * \\
(0,0008)\end{array}$ & $\begin{array}{c}, 0038^{* * * *} \\
(0,0008)\end{array}$ & $\begin{array}{c}0,0053^{* * * *} \\
(0,0011)\end{array}$ & $\begin{array}{c}, 0100 * * * \\
(0,0027)\end{array}$ & 0,0290 \\
\hline Teste2 & $\begin{array}{l}\text { Receita } \\
\text { Primária }\end{array}$ & $\begin{array}{c}0,0190 * * * \\
(0,0070)\end{array}$ & $\begin{array}{c}0,0094 \\
(0,0061)\end{array}$ & $\begin{array}{l}0,0107^{*} \\
(0,0057)\end{array}$ & $\begin{array}{c}0,0137 * * \\
(0,0065)\end{array}$ & $\begin{array}{l}0,0195^{*} \\
(0,0101)\end{array}$ & $\begin{array}{c}0,0219 \\
(0,0145)\end{array}$ & 0,4700 \\
\hline Teste3 & Arrecadação & $\begin{array}{c}0,0010 \\
(0,0019)\end{array}$ & $\begin{array}{c}-0,0017 * * \\
(0,0007)\end{array}$ & $\begin{array}{c}0,0001 \\
(0,0010)\end{array}$ & $\begin{array}{c}0,0003 \\
(0,0014)\end{array}$ & $\begin{array}{l}-0,0011 \\
(0,0024)\end{array}$ & $\begin{array}{c}0,0014 \\
(0,0049)\end{array}$ & 0,0860 \\
\hline Teste4 & $\begin{array}{c}\text { Transferências } \\
\text { Voluntárias }\end{array}$ & $\begin{array}{l}0,0043 * * \\
(0,0018)\end{array}$ & $\begin{array}{c}0 \\
(0,0000)\end{array}$ & $\begin{array}{c}0,0007 * * * \\
(0,0000)\end{array}$ & $\begin{array}{c}0,0019 \text { *** } \\
(0,0004)\end{array}$ & $\begin{array}{c}0,0032 * * * \\
(0,0007)\end{array}$ & $\begin{array}{c}0,0036 * * \\
(0,0016)\end{array}$ & 0,0940 \\
\hline Teste5 & $\begin{array}{l}\text { Despesas } \\
\text { Primárias }\end{array}$ & $\begin{array}{l}0,0132 * \\
(0,0069)\end{array}$ & $\begin{array}{l}0,0108 * \\
(0,0059)\end{array}$ & $\begin{array}{c}0,0055 \\
(0,0064)\end{array}$ & $\begin{array}{c}0,0102 \\
(0,0066)\end{array}$ & $\begin{array}{c}0,0120 \\
(0,0082)\end{array}$ & $\begin{array}{l}0,01750 \\
(0,0150)\end{array}$ & 0,4660 \\
\hline Teste6 & $\begin{array}{l}\text { Gastos com } \\
\text { Pessoal }\end{array}$ & $\begin{array}{c}0,0047 \\
(0,0029)\end{array}$ & $\begin{array}{c}0,0032 \\
(0,0029)\end{array}$ & $\begin{array}{c}0,0038 \\
(0,0030)\end{array}$ & $\begin{array}{c}0,0039 \\
(0,0032)\end{array}$ & $\begin{array}{c}0,0003 \\
(0,0041)\end{array}$ & $\begin{array}{c}0,0013 \\
(0,0056)\end{array}$ & 0,4830 \\
\hline Teste7 & $\begin{array}{c}\text { Gastos } \\
\text { Investimentos }\end{array}$ & $\begin{array}{l}0,0039^{* * *} \\
(0,0020)\end{array}$ & $\begin{array}{c}0,0012 \\
(0,0008)\end{array}$ & $\begin{array}{c}0,0025^{* *} \\
(0,0010)\end{array}$ & $\begin{array}{c}0,0030^{* *} \\
(0,0015)\end{array}$ & $\begin{array}{c}0,0030 \\
(0,0019)\end{array}$ & $\begin{array}{c}0,0061 \\
(0,0040)\end{array}$ & 0,1380 \\
\hline Teste8 & Gastos Sociais & $\begin{array}{c}0,0101 * * * \\
(0,0038)\end{array}$ & $\begin{array}{c}0,0044 \\
(0,0034)\end{array}$ & $\begin{array}{c}0,0073 * * \\
(0,0031)\end{array}$ & $\begin{array}{l}0,0063 * * \\
(0,0032)\end{array}$ & $\begin{array}{c}0,0091 \\
(0,0058)\end{array}$ & $\begin{array}{l}0,0161 * \\
(0,0082)\end{array}$ & 0,5470 \\
\hline
\end{tabular}

Fonte: Elaborado pela autora.

Nota: Erro padrão entre parênteses $* * * \mathrm{p}<0.01, * * \mathrm{p}<0.05, * \mathrm{p}<0.1$.

Com relação aos gastos sociais, o topo da distribuição é a que mais sofre influência da expectativa de reeleição, chegando a um crescimento de $1,61 \%$ em porcentagem do PIB municipal ao erro padrão de $10 \%$.

\subsection{Conclusão}

Este trabalho procurou analisar a relação entre política fiscal e reeleição para os municípios brasileiros entre os anos de 2001 a 2012. Para as análises, utilizaram-se o método de dados em painel com efeitos fixos e o método de diferenças em diferenças entre quantis.

Em geral, a principal contribuição do trabalho foram as evidências empíricas de que a expectativa de reeleição municipal influi em aspectos da política fiscal do ente, em particular no resultado primário. Esse resultado reforça as ideias dos modelos de controle eleitoral e contradiz os receios de abuso dos gastos públicos em caso de reeleição. Pelo contrário, os resultados encontrados indicam que prefeitos em primeiro mandato com expectativas de reeleição apresentam uma política fiscal mais sustentável: geração de receitas em volume suficiente para cobrir as despesas sem comprometer sua capacidade de administrar a dívida existente. 
Além da análise principal, outras sete categorias de receitas e despesas foram analisadas. Dos resultados encontrados pode-se inferir que prefeitos com expectativas de reeleger-se, em média, reduzem os gastos rígidos (gastos com pessoal) e difíceis de serem reduzidos no curto prazo, reduzem os gastos com investimento de capital; no entanto, aumentam os gastos sociais.

No lado da receita, a expectativa de reeleição tem um efeito positivo no recebimento de recursos via transferências voluntárias. Nas análises entre quantis pode-se notar que esse efeito é bastante significativo a partir do quantil 0,25 e tende a aumentar nos municípios que mais recebem transferências voluntárias.

Verificou-se um resultado bastante significativo no nível de competitividade, indicando que quanto maior é a competitividade nas eleições para prefeitos, no pleito imediatamente anterior ao ano analisado, menores são as transferências voluntárias da União para os municípios. Esse resultado indica que, em média, o governo federal usa a estratégia de aplicar seus recursos em eleitores mais fiéis e reforça o modelo de core-voters.

Em geral, é possível inferir dos resultados que os potenciais efeitos do fim da reeleição para cargos do Executivo sobre as finanças públicas subnacionais podem ter o efeito adverso de reduzir ainda mais o já delicado equilíbrio das contas dos municípios. Em suma, o presente trabalho chama a atenção para os efeitos nocivos potenciais do fim da reeleição sobre a política fiscal subnacional. 


\section{ANEXO A - Anexo do Ensaio 1}

\section{A.1 - Resultado de dados em painel para o modelo contendo variáveis de controle orçamentárias}

As análises a seguir incluem variáveis de controle referentes às instituições orçamentárias. A mesma pergunta de pesquisa será respondida: prefeitos em primeiro mandato e com expectativas de reeleição são mais cautelosos com as finanças públicas municipais? Para responder essa questão, utilizou-se o modelo de dados em painel com efeitos fixos dado abaixo:

$$
\begin{aligned}
\text { Fiscal }_{i t}=\alpha_{i} & +\beta_{1} \cdot G 1_{i t}+\beta_{2} \cdot G 2_{i t}+\gamma \text { Pessoais }_{i t}+\delta \text { Outras Políticas }_{i t}+\mu \text { Sociais }_{i t} \\
& + \text { OInstituições Orçamentárias }+c_{i}+\epsilon_{i t}
\end{aligned}
$$

As variáveis dependentes para essa análise são: resultado primário em porcentagem do Produto Interno Bruto (PIB) municipal, receitas primárias em porcentagem do PIB municipal, despesas primárias em porcentagem do PIB municipal. O conjunto de variáveis referentes às instituições orçamentárias pretende medir o efeito das características orçamentárias no indicador de sustentabilidade fiscal do município (Tabela A1).

Tabela A1 - Resumo das variáveis de controle referente às características institucionais

\begin{tabular}{|c|c|c|c|}
\hline \multicolumn{3}{|c|}{ Características das Instituições Orçamentárias (Instituições) } & $\begin{array}{c}\text { Sinal } \\
\text { esperado }\end{array}$ \\
\hline $\begin{array}{l}\text { Ind. Receita } \\
\text { Própria }\end{array}$ & $\begin{array}{l}\text { Indicador de Receita gerada no } \\
\text { município }\end{array}$ & Ind. Receita $=\frac{\text { Receita Própria }}{\text { Receita Corrente Líquida }}$ & + \\
\hline $\begin{array}{l}\text { Ind. Gasto com } \\
\text { Pessoal }\end{array}$ & $\begin{array}{l}\text { Indicador de Gastos com Pessoal } \\
\text { no município }\end{array}$ & Ind. Pessoal $=\frac{\text { Gastos com Pessoal }}{\text { Receita Corrente Líquida }}$ & + \\
\hline $\begin{array}{l}\text { Ind. } \\
\text { Investimento }\end{array}$ & $\begin{array}{l}\text { Indicador de Gastos com } \\
\text { Investimento no município }\end{array}$ & Ind. Receita $=\frac{\text { Gastos com Investimento }}{\text { Receita Corrente Líquida }}$ & + \\
\hline Ind. Liquidez & $\begin{array}{l}\text { Indicador de Liquidez das } \\
\text { contas municipais }\end{array}$ & Ind. Liquidez $=\frac{\text { Restos a Pagar }}{\text { Ativo Financeiro }}$ & + \\
\hline $\begin{array}{l}\text { Ind. } \\
\text { Custo Dívida }\end{array}$ & $\begin{array}{l}\text { Indicador de Custo de Dívida } \\
\text { do município }\end{array}$ & Ind. Custo Dívida $=\frac{\text { Juros }+ \text { Amortizacçoes }}{\text { Receita Líq. } \text { Real }}$ & + \\
\hline
\end{tabular}
orçamentárias 
Os dados utilizados para a construção dos indicadores foram FINBRA dos anos de 2000 a 2001. Os resultados para a estimação do modelo estão na Tabela A2.

Tabela A2 - Resultados para os testes de dados em painel com efeitos fixos

\begin{tabular}{|c|c|c|c|}
\hline Variáveis & $\begin{array}{c}\text { Teste } 1 \\
\text { Resultado Primário } \\
\text { it }\end{array}$ & $\begin{array}{c}\text { Teste } 2 \\
\text { Receita Primária } \\
\end{array}$ & $\begin{array}{c}\text { Teste } 3 \\
\text { Despesa Primária }_{i t}\end{array}$ \\
\hline \multirow[t]{2}{*}{ G1 } & $0,0614 * * *$ & $0,1620 * * *$ & $0,1000^{*}$ \\
\hline & $(0,0173)$ & $(0,0538)$ & $(0,0527)$ \\
\hline \multirow[t]{2}{*}{$\mathrm{G} 2$} & $-0,0045$ & $-0,0379$ & $-0,0334$ \\
\hline & $(0,0282)$ & $(0,0862)$ & $(0,0819)$ \\
\hline \multirow[t]{2}{*}{ Ind. de Competitividade no Executivo } & $-0,0060$ & 0,0034 & 0,0095 \\
\hline & $(0,0125)$ & $(0,0393)$ & $(0,0389)$ \\
\hline \multirow[t]{2}{*}{ Fracionalização do Legislativo } & 0,2200 & $-0,0970$ & $-0,3170$ \\
\hline & $(0,1540)$ & $(0,4940)$ & $(0,4670)$ \\
\hline \multirow[t]{2}{*}{ Ind. de Participação Popular } & $-0,0009$ & 0,0036 & 0,0045 \\
\hline & $(0,0014)$ & $(0,0047)$ & $(0,0046)$ \\
\hline \multirow[t]{2}{*}{ Ideologia } & $-0,0058$ & $0,1050 * * *$ & $0,1110^{* * *}$ \\
\hline & $(0,0089)$ & $(0,0285)$ & $(0,0278)$ \\
\hline \multirow[t]{2}{*}{ Id. Prefeito e Presidente } & $0,1840 * * *$ & $0,5810 * * *$ & $0,3970 * * *$ \\
\hline & $(0,0347)$ & $(0,0888)$ & $(0,0851)$ \\
\hline \multirow[t]{2}{*}{ Id Prefeito e Coalizão Presidente } & $0,1170 * * *$ & $0,6580 * * *$ & $0,5410 * * *$ \\
\hline & $(0,0307)$ & $(0,0868)$ & $(0,0830)$ \\
\hline \multirow[t]{2}{*}{ Id Prefeito e Governador } & $-0,0212$ & 0,0524 & 0,0736 \\
\hline & $(0,0190)$ & $(0,0591)$ & $(0,0561)$ \\
\hline \multirow[t]{2}{*}{ Id Prefeito e Coalizão do Governador } & 0,0113 & 0,0372 & 0,0260 \\
\hline & $(0,0260)$ & $(0,0828)$ & $(0,0798)$ \\
\hline \multirow[t]{2}{*}{ Idade do Prefeito } & $0,0033 * *$ & $-0,0041$ & $-0,0073$ \\
\hline & $(0,0015)$ & $(0,0047)$ & $(0,0047)$ \\
\hline \multirow[t]{2}{*}{ Escolaridade do Prefeito } & 0,0064 & $-0,0056$ & $-0,0121$ \\
\hline & $(0,0076)$ & $(0,0287)$ & $(0,0277)$ \\
\hline \multirow[t]{2}{*}{ Sexo } & $-0,0069$ & $-0,2900$ & $-0,2830$ \\
\hline & $(0,0482)$ & $(0,1790)$ & $(0,1730)$ \\
\hline \multirow[t]{2}{*}{ Receita Própria } & $1,1570 * * *$ & $2,2260 * * *$ & $1,0690 * *$ \\
\hline & $(0,1530)$ & $(0,4800)$ & $(0,4190)$ \\
\hline \multirow[t]{2}{*}{ Gasto Pessoal } & $1,9090 * * *$ & $1,5500 * * *$ & $-0,3580 * * *$ \\
\hline & $(0,0656)$ & $(0,1280)$ & $(0,1240)$ \\
\hline \multirow[t]{2}{*}{ Liquidez } & $0,6400 * * *$ & $0,5790 * * *$ & $-0,0599$ \\
\hline & $(0,0276)$ & $(0,0730)$ & $(0,0675)$ \\
\hline \multirow[t]{2}{*}{ Custo da Dívida } & $-1,1740 * * *$ & $0,2850 *$ & $1,4590 * * *$ \\
\hline & $(0,0806)$ & $(0,1710)$ & $(0,1630)$ \\
\hline \multirow[t]{2}{*}{ Investimento } & $-0,9360 * * *$ & $2,9560 * * *$ & $3,8920 * * *$ \\
\hline & $(0,0350)$ & $(0,0926)$ & $(0,0891)$ \\
\hline \multirow[t]{2}{*}{ Taxa de Analfabetismo } & $-0,0273 * * *$ & $-0,2150 * * *$ & $-0,1880 * * *$ \\
\hline & $(0,0092)$ & $(0,0383)$ & $(0,0368)$ \\
\hline \multirow[t]{2}{*}{ Mortalidade } & $-0,0150 * * *$ & $-0,1170 * * *$ & $-0,1020 * * *$ \\
\hline & $(0,0034)$ & $(0,0128)$ & $(0,0120)$ \\
\hline \multirow[t]{2}{*}{ População Economicamente Ativa } & $-0,2690$ & $1,4110 *$ & $1,6810 * *$ \\
\hline & $(0,2800)$ & $(0,8000)$ & $(0,7620)$ \\
\hline \multirow[t]{2}{*}{ Constante } & $121,0000 * * *$ & 30,3300 & $-90,6100 * * *$ \\
\hline & $(8,8670)$ & $(33,0400)$ & $(31,6100)$ \\
\hline R-quadrado & 0,1190 & 0,1740 & 0,2130 \\
\hline ANO & SIM & SIM & SIM \\
\hline
\end{tabular}

Fonte: Elaborado pela autora. 
A Tabela A2 apresenta os resultados utilizando-se todas as variáveis de controle descritas acima para o teste 1 , teste 2 e teste 3 . Os resultados indicam que municípios em que os prefeitos são de primeiro mandato e que possuem expectativas de reeleição (G1) tendem a aumentar as despesas e as receitas primárias municipais em uma proporção de $0,10 \%$ e $0,16 \%$ do Produto Interno Bruto municipal, respectivamente. No entanto, como o efeito no resultado primário também foi positivo, infere-se que o aumento da despesa foi coberto com o aumento da receita, resultando em um superávit primário. Desse modo, o efeito positivo sobre o resultado primário sugere que prefeitos com expectativas de reeleição apresentam uma política fiscal mais sustentável com a geração de receitas em volume suficiente para cobrir as despesas sem comprometer sua capacidade de administrar a dívida existente. Esse resultado está de acordo com Meneguin, Bugarin e Carvalho (2005) que concluíram que quando há possibilidade de reeleição, o prefeito é mais responsável com a política fiscal do município, pois ele terá que arcar com o ônus futuro de um endividamento público. No entanto, os municípios cujos prefeitos de primeiro mandato não pleitearam a renovação do cargo eletivo não apresentam coeficientes significativos, de modo que podemos concluir que esse grupo de prefeitos age de forma semelhante aos prefeitos em segundo mandato no que diz respeito ao superávit primário.

No que tange ao conjunto de variáveis com características políticas, notou-se um resultado bastante significativo da variável ideologia para o teste 2 e para o teste 3 , indicando que quanto mais de direita, maiores serão suas receitas e suas despesas. No entanto, a ideologia não mostrou um efeito significativo no resultado primário.

As variáveis referentes aos alinhamentos políticos entre os níveis de governo mostram que os prefeitos cujo partido pertence à coalizão de partidos do presidente da República apresentam um efeito positivo no resultado primário e também nas despesas e receitas primárias. Dessa forma, pode-se deduzir que prefeitos alinhados politicamente com o Executivo federal possuem uma receita primária mais alta, possivelmente em função de transferências voluntárias - como argumentado por Ferreira e Bugarin (2005; 2007) e Bugarin e Marciniuk (2016) - e uma despesa primária mais baixa.

Do conjunto de variáveis que apresentam as características particulares dos prefeitos, é interessante o resultado sobre a variável idade, que é estatisticamente significativa e apresenta um sinal positivo no resultado primário, sugerindo que prefeitos com mais idade são, em média, mais prudentes com o controle das contas municipais. Note que a variável não possui significância estatística nas regressões desagregadas referentes às receitas e às despesas primárias 
Com relação ao conjunto das variáveis que representam o controle institucional, notamos que, com exceção do parâmetro referente aos limites do custo da dívida e dos gastos com investimentos, todas as variáveis apresentam efeitos positivos e bastante significativos nos modelos, indicando que desempenhos melhores em indicadores de limites fiscais refletem em melhores resultados nas contas primárias municipais. O parâmetro associado ao indicador de autonomia municipal apresenta um efeito positivo no teste 1 e nas regressões de suporte, teste 2 e teste 3 , indicando que municípios com maior autonomia orçamentária, além de terem um aumento nas receitas, conseguem aumentar seus gastos, no entanto são mais comprometidos com a sustentabilidade fiscal. Em média, um aumento de 1,00\% no índice indica um aumento de $1,15 \%$ no resultado primário para os municípios com prefeitos de primeiro mandato.

Com relação aos indicadores relativos às dívidas, nota-se que o de curto prazo (indicador de liquidez) se apresenta positivo e o aumento de um ponto percentual no indicador reflete em 0,64\% no resultado primário pelo Produto Interno Bruto. Diferentemente, o indicador de custos da dívida de longo prazo indica que quanto mais o município se preocupa com o pagamento dos juros da dívida e tenta deixar tais contas em dia, um efeito negativo é refletido no resultado primário.

Do indicador de investimentos pode-se inferir que quanto maior os gastos com investimentos de capital, maiores são os reflexos negativos no indicador de resultado primário. Quanto mais sustentável é o município neste quesito, o reflexo nas receitas primárias é menor do que nas despesas primárias, implicando em um efeito negativo nas contas de resultado primário municipal.

Com relação ao grupo das características municipais e temporais, a variável analfabetismo apresenta resultados bastante interessantes. Nota-se que quanto maior a taxa de analfabetismo, mais negativos são os efeitos nas despesas públicas e nas receitas públicas implicando em um efeito negativo no resultado primário. Nesse contexto, pode-se sugerir que quanto maiores as taxas de analfabetismo mais problemas sociais são encontrados no município e menor é a captação de impostos pela prefeitura acarretando um efeito bastante negativo na receita. Esse efeito é maior do que o efeito na despesa primária e gera um coeficiente negativo para o indicador de resultado primário. 


\section{A.2 - Testes para o modelo de dados em painel}

Tabela A3 - Testes para definição entre efeito fixo e efeitos aleatórios

\begin{tabular}{lllccc}
\hline \multirow{2}{*}{ Testes } & Variáveis & \multicolumn{2}{c}{ Teste de Hausman } & \multicolumn{2}{c}{ Teste de Chow } \\
\cline { 2 - 5 } & Dependentes & $\chi^{2}(15)$ & Prob $>\chi^{2}$ & $\mathrm{~F}$ & Prob>F \\
\hline Teste1 & Resultado primário & 41,92 & 0,002 & $\mathrm{~F}(5431,45456)=1,44$ & 0,0000 \\
Teste2 & Receita primária & 830,68 & 0,000 & $\mathrm{~F}(5431,45456)=4,14$ & 0,0000 \\
Teste3 & Arrecadação & 66,92 & 0,000 & $\mathrm{~F}(5431,45456)=11,52$ & 0,0000 \\
Teste4 & Tranf. voluntárias & 333,86 & 0,000 & $\mathrm{~F}(5435,7456)=2,70$ & 0,0000 \\
Teste5 & Despesas primárias & 808,10 & 0,000 & $\mathrm{~F}(5431,45456)=4,04$ & 0,0000 \\
Teste6 & Gasto com pessoal & 1271,12 & 0,000 & $\mathrm{~F}(5431,45456)=4,38$ & 0,0000 \\
Teste7 & Investimento & 318,97 & 0,000 & $\mathrm{~F}(5431,45456)=4,02$ & 0,0000 \\
Teste8 & Gastos sociais & 1385,41 & 0,000 & $\mathrm{~F}(5431,45456)=3,54$ & 0,0000 \\
\hline
\end{tabular}

Fonte: Elaborado pela autora.

Tabela A4 - Teste de multicolinearidade e teste para autocorrelação de todas as equações

\begin{tabular}{llclc}
\hline \multirow{2}{*}{ Testes } & Variáveis & \multicolumn{2}{c}{$\begin{array}{c}\text { Teste de } \\
\text { Multicolinearidade }\end{array}$} & \multicolumn{2}{c}{$\begin{array}{c}\text { Wutocorrelação de } \\
\text { Dependentes }\end{array}$} & VIF & $\mathrm{F}(1,5345)$ & Prob>F \\
\cline { 2 - 5 } & Resultado primário & 1,55 & 0,095 & 0,7576 \\
Teste1 & Receita primária & 1,57 & 802,601 & 0,000 \\
Teste2 & Arrecadação & 1,57 & 26,848 & 0,000 \\
Teste4 & Tranf. voluntárias & 1,56 & 17,092 & 0,000 \\
Teste5 & Despesas primárias & 1,57 & 706,841 & 0,000 \\
Teste6 & Gasto com pessoal & 1,57 & 1433,652 & 0,000 \\
Teste7 & Investimento & 1,57 & 3,780 & 0,0519 \\
Teste8 & Gastos sociais & 1,57 & 19,019 & 0,000 \\
\hline
\end{tabular}

Fonte: Elaborado pela autora. 
A.3 - Testes para a metodologia de diferenças e diferenças

Tabela A.5 - Teste da hipótese nula de que os coeficientes entre os diferentes quantis são iguais

\begin{tabular}{|c|c|c|c|c|c|c|c|c|c|c|c|c|c|c|}
\hline & \multicolumn{2}{|c|}{ Resultado Primário } & \multicolumn{2}{|c|}{ Receita Primária } & \multicolumn{2}{|c|}{ Arrecadação } & \multicolumn{2}{|c|}{$\begin{array}{c}\text { Transferências } \\
\text { Voluntárias }\end{array}$} & \multicolumn{2}{|c|}{ Despesa Primária } & \multicolumn{2}{|c|}{ Gasto com Pessoal } & \multicolumn{2}{|c|}{ Gasto Social } \\
\hline & $F(4,1369)$ & Prob $>F$ & $\mathrm{~F}(4,1369)$ & Prob $>F$ & $\mathrm{~F}(4,1369)$ & Prob $>F$ & $\mathrm{~F}(4,1369)$ & Prob $>F$ & $\mathrm{~F}(4,1369)$ & Prob $>F$ & $\mathrm{~F}(4,1369)$ & Prob $>F$ & $\mathrm{~F}(4,1369)$ & Prob $>F$ \\
\hline ICEx & 0,66 & 0,6197 & 2.18 & 0.0689 & 0,79 & 0,5310 & 1,34 & 0,2588 & 1,11 & 0,3496 & 1,22 & 0,3001 & 1,02 & 0,3975 \\
\hline Frag. & 1,12 & 0,3475 & 2.79 & 0.0250 & 1,28 & 0,2739 & 2,17 & 0,0893 & 2,24 & 0,0628 & 1,00 & 0,4043 & 3,07 & 0,0156 \\
\hline $\mathrm{PPi}$ & 3,21 & 0,0123 & 1.77 & 0.1327 & 1,58 & 0,1770 & 11,11 & 0,0000 & 1,94 & 0,1020 & 2,21 & 0,0658 & 3,46 & 0,0080 \\
\hline Ideologia & 1,20 & 0,3082 & 0.47 & 0.7608 & 0,08 & 0,9894 & 1,89 & 0,1293 & 0,61 & 0,6545 & 0,90 & 0,4615 & 0,42 & 0,7927 \\
\hline Id_Pres & 1,75 & 0,1372 & 0.21 & 0.9331 & 2,84 & 0,0230 & 1,29 & 0,2771 & 0,40 & 0,8097 & 1,51 & 0,1966 & 0,88 & 0,4741 \\
\hline Id_Gov & 0,53 & 0,7153 & 0.62 & 0.6471 & 0,55 & 0,6993 & 1,95 & 0,1193 & 0,40 & 0,8115 & 0,53 & 0,7117 & 0,41 & 0,8002 \\
\hline Id_CoaGov & 2,66 & 0,0311 & 0.56 & 0.6899 & 0,24 & 0,9156 & 0,10 & 0,9599 & 0,82 & 0,5111 & 1,96 & 0,0987 & 0,60 & 0,6620 \\
\hline Idade & 1,01 & 0,3985 & 1.82 & 0.1226 & 0,78 & 0,5384 & 1,25 & 0,2894 & 1,71 & 0,1453 & 0,38 & 0,8231 & 2,73 & 0,0277 \\
\hline Escola & 3,96 & 0,0034 & 1.90 & 0.1089 & 0,30 & 0,8776 & 0,70 & 0,5504 & 2,10 & 0,0788 & 0,39 & 0,8174 & 0,91 & 0,4562 \\
\hline Sexo & 0,60 & 0,6613 & 0.25 & 0.9123 & 1,53 & 0,1913 & 0,57 & 0,6365 & 0,35 & 0,8440 & 1,31 & 0,2627 & 0,20 & 0,9397 \\
\hline Analf & 1,85 & 0,1173 & 3.42 & 0.0086 & 1,52 & 0,1927 & 4,60 & 0,0033 & 2,97 & 0,0185 & 1,74 & 0,1383 & 3,11 & 0,0148 \\
\hline Mort. & 2,99 & 0,0180 & 2.95 & 0.0193 & 1,47 & 0,2096 & 5,95 & 0,0005 & 2,28 & 0,0589 & 0,94 & 0,4419 & 2,21 & 0,0761 \\
\hline Gini & 0,33 & 0,8603 & 0.97 & 0.4232 & 1,01 & 0,4019 & 3,08 & 0,0266 & 0,65 & 0,6293 & 0,71 & 0,5828 & 0,51 & 0,7249 \\
\hline Pop & 0,20 & 0,9392 & 0.95 & 0.4362 & 1,68 & 0,1510 & 0,20 & 0,8934 & 0,83 & 0,5056 & 0,84 & 0,4998 & 0,47 & 0,7567 \\
\hline
\end{tabular}

Fonte: Elaborado pela autora.

Seed utilizada: 1010 


\title{
Ensaio 2 - Análise da presença de motivação partidária nas transferências voluntárias da União
}

\begin{abstract}
Resumo
Este artigo investiga empiricamente se há uma distribuição mais favorável das transferências voluntárias federais para municípios cujo partido do prefeito possui identidade partidária com os partidos que possuem influência política no município. Os resultados sugerem a existência desse favorecimento e são particularmente interessantes nesse momento em que o Brasil passa por uma crise de ordem política e de credibilidade no governo, bastante evidenciados pelos vários escândalos de corrupção envolvendo barganhas políticas utilizando transferências voluntárias. Por meio de estatísticas descritivas mostramos quais regiões sofrem influência política partidária e também criamos uma medida para a identificação partidária entre o Poder Legislativo federal e o Poder Executivo municipal com base no indicador de Quociente Locacional proposto por Bendavid-Val. A contribuição desse trabalho é ir além da relação entre prefeitos e o presidente da República e investigar o efeito da influência dos parlamentares federais na distribuição das transferências voluntárias.
\end{abstract}

Palavras-chave: Transferências Voluntárias. Convênios Públicos. Quociente Locacional. Identidade Partidária.

\begin{abstract}
This paper investigates empirically if the distribution of federal voluntary transfers is biased towards townships in which the mayor's party has party identity with the coalition with political dominance in the township. The results suggest that this bias does exist, and are particularly interesting in Brazil's current situation, where a political crisis hampered govenment's credibility, and a number of corruption scandals emerged with political bargains that involved voluntary transfers. Using descriptive statistics we show which regions are affected by political partisanship and we create an index for party identity between the federal legislature and the municipal executive branch, based on Bendavid-Val's locational quotients. The contribution of our work is to go beyond the mayor-president relationship, and to investigate how the federal legislature affects the distribution of voluntary transfers.
\end{abstract}


Keywords: federal voluntary transfers, Co-operative covenants, location quotient, partisan identity 


\subsection{Introdução}

A descentralização fiscal introduzida pela Constituição Federal de 1988 (BRASIL, 1988) e o consequente fortalecimento dos municípios foram responsáveis por profundas mudanças nas instituições dos governos locais, alterando os sistemas de decisões e as práticas dos atores políticos em todos os níveis de governo. Com isso, os municípios se tornaram os responsáveis pela implantação de grande parte dos programas do governo federal e pela alocação de parte considerável dos recursos nacionais. No entanto, apesar de o Brasil optar por um sistema fiscal descentralizado para a prestação de serviços públicos, adotou um sistema de arrecadação de tributos centralizado e com posterior redistribuição para os governos locais.

Sob a lógica do federalismo brasileiro, as transferências de recursos entre os entes federativos se tornaram uma ferramenta de extrema importância para viabilizar o melhor desempenho dos entes governamentais. Elas têm respaldo em argumentos econômicos equidade e eficiência - ou políticos - centralização ou descentralização do poder político (BARBOSA, 1998). Elas, em geral, são consideradas fundamentais para suprir a lacuna entre a capacidade e a necessidade de se prover serviços públicos de modo uniforme para todos os cidadãos e, além disso, para resolver problemas de externalidades, tais como o efeito spillover (efeito transbordamento) ${ }^{5}$.

Apesar de sua importância, a partilha do "bolo tributário" via transferência pode gerar ineficiência na alocação dos recursos públicos. Um exemplo bastante debatido é a divisão dos recursos do Fundo de Participação dos Municípios (FPM), cujo desenho beneficia particularmente os municípios pequenos (com menos de 10.500 habitantes) e prejudicam grandes centros, em especial aqueles situados em periferias metropolitanas (municípios com grande demanda por serviços públicos). Portanto, um bom desenho do sistema de transferências de recursos governamentais é um elemento importante tanto para o equilíbrio fiscal quanto para a qualidade da intervenção do setor público na economia (MENDES, MIRANDA \& COSIO, 2008).

Grande parte do montante enviado aos entes supranacionais é distribuída sob a forma de transferências constitucionais ou legais. As transferências constitucionais consistem na distribuição de recursos provenientes da arrecadação de tributos federais ou estaduais, aos

\footnotetext{
5 Spillover ou efeito transbordamento reflete como o incremento do gasto de uma determinada unidade da federação influência outra unidade federativa próxima. Tipicamente, um prefeito de um município não está preocupado com o transbordamento de suas decisões de políticas públicas, o que faz com que as quantidades decididas descentralizadamente não sejam ótimas do ponto de vista social agregado.
} 
estados, Distrito Federal e municípios, com base em dispositivos constitucionais como os fundos de participação estaduais ou municipais. As transferências legais são reguladas por leis específicas e seus recursos são repassados para acorrer a despesas específicas, por exemplo, o Programa Nacional de Alimentação Escolar (PNAE), o Programa Nacional de Apoio ao Transporte do Escolar (PNATE), o Programa Dinheiro Direto na Escola (PDDE), entre outros.

Além desses tipos de transferências, os governos federal e estadual utilizam transferências voluntárias que, em regra, são viabilizadas por meio de convênios ou contratos de repasse. Grande parte dos recursos dessas transferências voluntárias é acrescida à repartição do orçamento federal por meio de emendas parlamentares visando ao atendimento de demandas locais específicas, tais como a construção de praças, quadras de esporte, ampliação de hospitais e escolas. Os recursos repassados via transferências voluntárias podem contemplar os municípios por meio de proposta do Poder Executivo via Lei Orçamentária Anual (municípios explicitamente contemplados no Orçamento Geral da União - OGU - ou aqueles que pertencem a alguma região contemplada) ou por meio de emendas parlamentares a essa proposta de Lei Orçamentária do Poder Executivo. Nesse contexto, o Congresso Nacional tem um importante papel na interligação entre o governo federal e os governos locais. As emendas parlamentares à Lei Orçamentária Anual (LOA) visam inserir os congressistas nas discussões do planejamento do orçamento federal, visto que os parlamentares são representantes legais dos anseios de seu eleitorado.

A legislação e a execução prática do orçamento da União em geral são caracterizadas pelo orçamento autorizativo das despesas, na qual parte dessas despesas pode ser contingenciada, isto é, o governo não tem a obrigação de realizar tudo o que está expresso na LOA. No que diz respeito às emendas parlamentares, a partir do exercício financeiro de 2015 instituiu-se legalmente o regime de "orçamento impositivo" em relação às emendas individuais pela Emenda Constitucional $n^{\circ} 86 / 2015$, as quais passaram a ser consideradas de execução obrigatória até o limite de $1,2 \%$ da receita corrente líquida realizada no exercício anterior. No entanto, até 2014 as despesas previstas via emendas parlamentares também eram de execução discricionária e não necessariamente eram realizadas pelo Poder Executivo. Nesse contexto, as transferências voluntárias, por definição, possuem um forte componente político, tanto por parte do Poder Executivo nacional, que tem o poder de executá-las, quanto do Poder Legislativo nacional, que tem o poder de alocar esses recursos nas áreas de seu interesse.

As discussões envolvendo as transferências voluntárias têm ganhado cada vez mais espaço na literatura e nos debates políticos, parte discutindo seus impactos positivos nas esferas 
política e econômica e parte apontando suas características catalisadoras de corrupção (ALVES \& SODRÉ, 2007). Os argumentos em defesa das transferências voluntárias, em particular as emendas parlamentares, partem da ideia de que elas são essenciais para que o governo federal alcance a sua governabilidade perante o parlamento (PEREIRA \& MUELLER, 2002; PEREIRA \& MUELLER, 2003), são um reforço ao vínculo entre representantes e representados (PEREIRA \& RENNÓ, 2001) e são importantes na redução das desigualdades regionais no Brasil (CARVALHO, 2009).

Em oposição, o principal ponto negativo levantado pela literatura especializada se refere ao caráter essencialmente clientelista das transferências voluntárias. Nesse contexto, os deputados e senadores podem usar seu poder político para solicitar aos ministérios a liberação de verba para os estados, as regiões ou municípios que representam com objetivos puramente políticos e eleitoreiros, de maneira que as regiões mais necessitadas tenderiam a ficar de fora da lista dos beneficiados. Desse modo, as transferências beneficiariam apenas os municípios com maior força política dentro do Congresso Nacional. Mainwaring (1991) defende que o uso político dos recursos públicos nas formas de patronagem, clientelismo e patrimonialismo geram um alto custo para a economia do país e também à legitimidade do sistema político.

O ex-presidente da República Fernando Henrique Cardoso chama atenção para o efeito negativo da sistemática orçamentária no que se refere às emendas parlamentares sobre a legitimidade do governo. Para o ex-presidente:

[...] por menores que sejam os recursos de transferências via emendas, estas infectam
a percepção do uso de recursos públicos, pois são noticiadas com alarido, como se
tudo fosse clientelismo e todo clientelismo em si mesmo fosse corrupção. O resultado
perverso disso é que os ministros ou gestores públicos incumbidos da relação com os
parlamentares sofrem considerável desgaste, na medida em que não cedem às
pressões. E quando cedem, ainda que nos limites da lei e do moralmente aceitável,
veem-se associados às piores práticas (CARDOSO, 2006).

Outro problema apontado é o insuficiente controle dos processos de aprovação e de execução das transferências voluntárias, os quais são fatores que facilitam atos ilícitos contra o erário público. Vários são os exemplos de escândalos que evidenciam as transferências voluntárias via emendas como um campo propício para atividades ilícitas. Um famoso exemplo sobre a manipulação das emendas parlamentares para usos ilícios foi o escândalo da Máfia dos Sanguessugas em 2006. Nesse esquema de corrupção, a quadrilha negociava com congressistas a liberação de emendas parlamentares destinadas a municípios específicos, cujos prefeitos já haviam sido previamente aliciados pelo grupo para efetivar a compra de ambulâncias. Com os recursos garantidos, as licitações municipais eram fraudadas e os preços superfaturados e, então, os excedentes eram distribuídos entre os diversos participantes do esquema. 
Este trabalho avalia empiricamente a relação entre a distribuição espacial dos votos para os partidos dos deputados da Câmara Federal e a sua relação com a distribuição de transferências voluntárias federais. Com esse objetivo, testa a hipótese de que as transferências voluntárias da União são direcionadas para os municípios cujos prefeitos são de partido da base governista em âmbito federal. Este trabalho inova ao utilizar a base de convênios públicos federais como proxies para as transferências voluntárias e ao incluir o Poder Legislativo nas análises sobre esse tema.

Esse estudo contribui à literatura ao evidenciar a existência de uma distribuição mais favorável das transferências voluntárias federais para municípios cujo partido do prefeito possui identidade partidária com os partidos que possuem influência política no município. Os resultados encontrados são particularmente interessantes nesse momento em que o Brasil passa por uma crise de ordem política e de credibilidade no governo, bastante evidenciados pelos vários escândalos de corrupção envolvendo barganhas políticas utilizando transferências voluntárias.

Além dessa introdução, o trabalho estrutura-se da seguinte forma: a seção 2 apresenta uma análise estatística sobre as transferências voluntárias. A seção 3 traz o referencial teórico sobre a influência das transferências voluntárias no funcionamento do sistema político brasileiro. A seção 4 faz uma análise estatística sobre a concentração dos votos por partido no Poder Legislativo federal. Na seção 5 a análise empírica é discutida com a apresentação do modelo e das variáveis utilizadas para os testes econométricos. Por fim, a seção 6 traz as conclusões finais desse ensaio.

\subsection{Panorama das transferências voluntárias - convênios}

A União, os estados, o Distrito Federal e os municípios têm competências distintas estabelecidas pela Constituição Federal de 1988, as quais abrangem diversas temáticas como saúde, educação, assistência social, transporte, saneamento básico. $\mathrm{Na}$ existência de um interesse comum e recíproco no que concerne à realização de obras públicas ou serviços públicos, a União realiza transferências voluntárias de recursos para outros entes federados. A operacionalização dessas transferências, em geral, acontece por meio de convênios ou contratos de repasses. Estes instrumentos orçamentários são bastante interessantes por apresentarem enorme flexibilidade e poder para lidar com situações específicas ou imprevistas da economia (MENDES, MIRANDA \& COSIO, 2008). 
Nas páginas seguintes, utiliza-se o termo convênio de forma genérica, se referindo aos demais instrumentos de transferências voluntárias de recursos como o contrato de repasse, termo de parceria, termo de fomento e termo de colaboração. Os repasses via convênios públicos, no período entre 2001 e 2012, alcançaram o montante de R \$ 109.997.656.438,94 e um total de 195.632 convênios firmados. Setorialmente, os recursos foram distribuídos conforme a Tabela 2.1. Pode ser observado que mais de $50 \%$ do montante total firmado foi por meio de apenas dois ministérios: Cidades e Saúde. O Ministério das Cidades firmou mais de $32 \%$ do montante total de convênios, o que significa um valor de $\mathrm{R} \$ 35.720 .036 .454,89$, e o Ministério da Saúde firmou quase $19 \%$ do montante total - o equivalente a R\$ 20.488.911.642,44 em 43.521 convênios firmados.

Tabela 2.1 - Características dos convênios firmados por setor - 2001-2012

\begin{tabular}{|c|c|c|c|c|c|c|}
\hline Ministério & $\begin{array}{r}\text { Montante Total } \\
\text { Firmado }\end{array}$ & $\begin{array}{r}\text { Valor Máximo } \\
\text { Firmado }\end{array}$ & $\begin{array}{r}\text { Valor Mínimo } \\
\text { Firmado }\end{array}$ & $\begin{array}{r}\text { Quantidade } \\
\text { Convênios } \\
\text { Firmados } \\
\end{array}$ & $\begin{array}{r}\text { Valor Médio } \\
\text { Convênios } \\
\text { Firmados } \\
\end{array}$ & FIRMADOS $_{1}^{\%}$ \\
\hline Cidades & $35.720 .036 .454,89$ & $687.271 .808,00$ & $3.369,32$ & 34.724 & $1.028 .684,38$ & $32,47 \%$ \\
\hline Saúde & $20.488 .911 .642,44$ & $160.697 .744,00$ & $4.803,81$ & 43.521 & $470.782,18$ & $18,63 \%$ \\
\hline Integração Social & $9.505 .206 .665,18$ & $257.463 .904,00$ & $14.827,98$ & 10.299 & $922.925,20$ & $8,64 \%$ \\
\hline Turismo & $9.253 .674 .460,47$ & $74.416 .128,00$ & $8.006,35$ & 19.916 & $464.635,19$ & $8,41 \%$ \\
\hline Educação & $8.506 .931 .868,37$ & $86.844 .424,00$ & 998,71 & 22.804 & $373.045,60$ & $7,73 \%$ \\
\hline Energias & $5.135 .069 .320,37$ & $97.561 .992,00$ & $1.209,45$ & 14.315 & $358.719,47$ & $4,67 \%$ \\
\hline $\begin{array}{l}\text { Agricultura, Pesca } \\
\text { e Abastecimento }\end{array}$ & $4.530 .414 .625,12$ & $16.235 .287,00$ & $8.461,84$ & 17.661 & $256.520,84$ & $4,12 \%$ \\
\hline Trabalho & $3.257 .759 .698,46$ & $168.864 .240,00$ & $14.317,09$ & 301 & $10.823 .121,92$ & $2,96 \%$ \\
\hline $\begin{array}{l}\text { Desenvolvimento } \\
\text { Agrário }\end{array}$ & $3.107 .819 .377,68$ & $10.677 .935,00$ & $4.812,74$ & 10.123 & $307.005,76$ & $2,83 \%$ \\
\hline $\begin{array}{l}\text { Desenvolvimento } \\
\text { Social }\end{array}$ & $3.002 .286 .026,14$ & $88.474 .944,00$ & 242,18 & 12.996 & $231.016,16$ & $2,73 \%$ \\
\hline Trabalho & $1.862 .671 .269,73$ & $133.380 .064,00$ & $48.013,40$ & 894 & $2.083 .524,91$ & $1,69 \%$ \\
\hline Cultura & $1.647 .865 .855,19$ & $29.707 .534,00$ & $3.676,31$ & 1.759 & $936.819,70$ & $1,50 \%$ \\
\hline Defesa & $1.263 .210 .064,38$ & $28.578 .542,00$ & $44.587,38$ & 1.776 & $711.266,92$ & $1,15 \%$ \\
\hline Justiça & $877.382 .256,03$ & $67.484 .352,00$ & $7.279,89$ & 1.033 & $849.353,58$ & $0,80 \%$ \\
\hline $\begin{array}{l}\text { Ciência e } \\
\text { Tecnologia }\end{array}$ & $768.273 .001,78$ & $32.680 .300,00$ & $16.012,70$ & 1.382 & $555.913,89$ & $0,70 \%$ \\
\hline $\begin{array}{l}\text { Desenvolvimento } \\
\text { indústria e } \\
\text { Comércio } \\
\text { Exterior }\end{array}$ & $557.438 .053,48$ & $66.764 .852,00$ & $40.031,75$ & 818 & $681.464,61$ & $0,51 \%$ \\
\hline $\begin{array}{l}\text { Presidência da } \\
\text { República }\end{array}$ & $407.387 .403,87$ & $161.023 .664,00$ & $8.060,92$ & 1.003 & $406.168,89$ & $0,37 \%$ \\
\hline Comunicações & $58.746 .299,90$ & $5.809 .447,50$ & $25.584,97$ & 278 & $211.317,62$ & $0,05 \%$ \\
\hline $\begin{array}{l}\text { Relações } \\
\text { Exteriores }\end{array}$ & $37.232 .136,00$ & $37.232 .136,00$ & $37.232 .136,00$ & 1 & $37.232 .136,00$ & $0,03 \%$ \\
\hline $\begin{array}{l}\text { Planejamento e } \\
\text { Orçamento }\end{array}$ & $4.815 .371,23$ & $2.280 .984,30$ & $330.163,63$ & 3 & $1.605 .123,74$ & $0,00 \%$ \\
\hline Minas e Energias & $4.524 .588,23$ & $578.521,19$ & $50.771,09$ & 25 & $180.983,52$ & $0,00 \%$ \\
\hline
\end{tabular}

Fonte: Secretaria do Tesouro Nacional. Tabela elaborada pela autora.

Nota: Os valores são deflacionados com a utilização do índice IPCA para o ano de 2014.

${ }^{\prime 1}$ : \% Firmados se referem à porcentagem de convênios firmados para o ministério específico em porcentagem do montante total firmado. 
A relação entre o montante (em reais de 1997) dos convênios firmados entre a União e os municípios e o montante dos convênios efetivamente executados (em reais de 1997) entre os anos de 1997 e 2012 nem sempre é perfeita, dado o próprio desenho do mecanismo de elaboração de execução do Orçamento Federal. Como já discutido na seção anterior, a legislação e a execução do orçamento da União até o ano de 2014 eram caracterizadas pelo orçamento autorizativo das despesas, em que parte dessas despesas podia ser contingenciada, isto é, o Poder Executivo não tinha a obrigação de realizar tudo o que estava expresso na Lei Orçamentária Anual. O Gráfico 1.1 apresenta uma relação que aponta para um grande descasamento entre esses montantes desde o ano de 2010, após um período de quatro anos em que a grande maioria dos convênios firmados foram executados.

Gráfico 2.1 - Montante de convênios firmados e convênios executados (reais) - 1997-2012

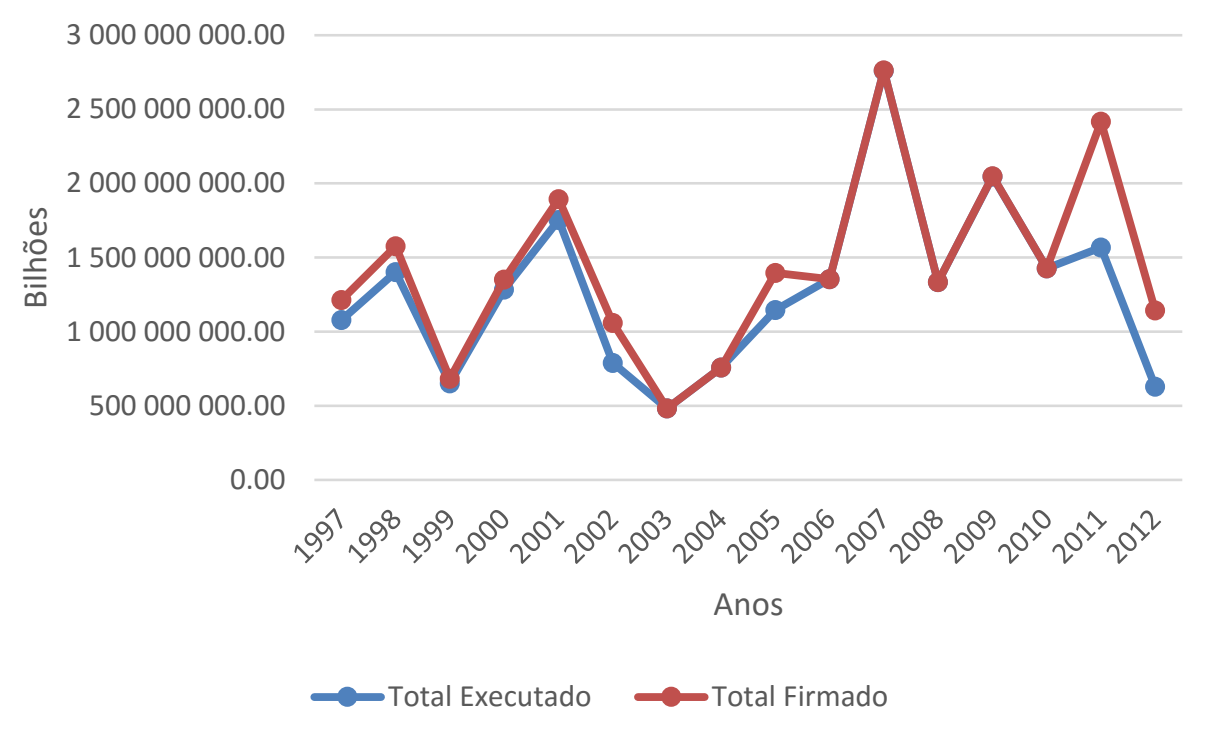

Fonte: Bugarin \& Marciniuk (2016).

Pode-se notar do Gráfico 1.1 que nos anos 2011 e 2012 há um descasamento bastante grande entre as duas séries. Esse fato pode ser explicado pela instabilidade política vivenciada já no primeiro ano de mandato da presidente Dilma Roussef. Em 2011 foram sete substituições de ministros, sendo que seis delas foram por denúncias de irregularidades. As manifestações populares contra a corrupção também começaram a se intensificar. 


\section{A influência das transferências voluntárias no funcionamento do sistema político brasileiro}

No Brasil, as eleições para cargos legislativos adotam o sistema de lista aberta. Neste sistema, cabem aos eleitores escolher se querem votar na legenda do partido ou diretamente nos candidatos de sua preferência. Ao final das votações, somam-se os votos recebidos por todos os candidatos de cada partido, adicionando-se ao total os sufrágios dados para a legenda. A quantidade de cadeiras que caberá a cada partido será determinada por uma fórmula (com base no Método $\mathrm{D}^{\prime} \mathrm{Hondt}^{6}$ ), e os candidatos de cada legenda serão ordenados de acordo com o número total de votos que receberam.

As principais críticas ao funcionamento do sistema político brasileiro, em geral, se baseiam no tipo de lista adotado. De acordo com a visão tradicional, a legislação eleitoral vigente no país reforça o comportamento individualista dos políticos, tanto na arena legislativa quanto na arena eleitoral, e dificulta a construção de um sistema partidário efetivo (MAINWARING, 1991). Neste contexto, a fragilidade do sistema político brasileiro seria uma consequência das regras eleitorais, em especial as regras para a eleição do legislativo, que é baseada em listas abertas com representação proporcional, as quais incentivam a utilização do voto pessoal (SILVA, 2010). Nesta visão, os partidos não são considerados um importante vínculo entre o eleitorado e o sistema político, sendo os políticos, de forma individual, os principais responsáveis por este vínculo. Esta interpretação sobre o sistema político brasileiro resulta no argumento de que os deputados, de forma individualizada, tendem a negociar recursos públicos com o Poder Executivo para suas áreas de interesse político, os chamados distritos eleitorais informais ${ }^{7}$, em troca de votos (AMES 1995a; 1995b; 2003). Como resultado, o sucesso de um político depende proporcionalmente da quantidade de recursos públicos gasto na sua zona de influência, pois estes recursos garantiriam seu controle político sobre essas regiões e, consequentemente, se converteriam em votos nas próximas eleições (SILVA, 2010).

Um dos principais pontos da visão tradicional sobre o sistema político brasileiro bastante contestado pela literatura especializada se refere à hipótese de existência de incentivos institucionais para a atuação individual dos políticos frente à participação dos partidos. Há duas linhas distintas que fazem críticas à esta hipótese: De um lado, há a discussão sobre a existência de um sistema parcial de influência entre as arenas legislativa e eleitoral, em que o papel dos

\footnotetext{
${ }^{6}$ Método D'Hondt é um método para alocar a distribuição de deputados e outros representantes eleitos na composição de órgãos de natureza colegial.

${ }^{7}$ Distritos eleitorais informais.
} 
partidos é considerado relevante no Congresso Nacional, porém fragilizada na arena eleitoral. De acordo com Pereira e Mueller (2003), as regras eleitorais incentivam os políticos a se comportarem individualmente - o que fragiliza os partidos na arena eleitoral - enquanto as regras internas do Congresso tornam o comportamento dos parlamentares dependentes da lealdade de seus respectivos partidos, o que os fortalece. Dessa forma, apesar da existência de coordenação no funcionamento do Congresso, essa não deve alterar as relações e os incentivos derivados do sistema eleitoral que levariam os deputados a usarem as emendas orçamentárias para expandir sua visibilidade em suas bases eleitorais (SILVA, 2010). Este vínculo individual é considerado fundamental para as ambições dos políticos (PEREIRA \& RENNÓ, 2001). A outra linha de discussão contrária à visão tradicional defende a existência de ações mais coordenadas entre os legisladores e seus partidos, inclusive na arena eleitoral. Apesar de não negar o caráter individualista das regras eleitorais, essa linha defende que estas não são suficientes para determinar um comportamento único dos políticos, visando o clientelismo, nem fragmentaria o Legislativo ao ponto de criar uma negociação individualizada com o Poder Executivo, como defende a linha tradicional (FIGUEIREDO \& LIMONGI, 2002; 2008; NICOLAU, 2006, entre outros). Esse grupo de pesquisadores assume a existência de outras motivações na atuação legislativa durante a elaboração do orçamento, dentre elas a influência partidária.

Segundo Figueiredo e Limongi (2008), os deputados não possuem total liberdade para alocar recursos baseados apenas em seus interesses particulares. A alocação das emendas está inteiramente subordinada à proposição orçamentária feita pelo Poder Executivo, em primeiro lugar, e depois está sujeito às determinações do partido por meio de seus líderes no Congresso Nacional. Dessa forma, a liberdade do deputado para escolher quais programas pretende emendar (programas previamente propostos pelo) e qual o local para onde pretende enviar o recurso, estará cerceada se houver diretrizes partidárias que o estimulem a direcionar os recursos para outras regiões (SILVA, 2010). Por exemplo, o deputado pode destinar recursos às regiões em que a presença de seu partido seja mais forte e, dessa forma, aumentar as suas chances de divulgar seu trabalho perante o eleitorado e reclamar as honras pelas obras executadas. Além disto, o deputado também pode levar em consideração, na hora de escolher o destino dos recursos, o partido do prefeito da cidade para onde está propenso a enviar uma emenda orçamentária, pois no caso de existir identidade partidária entre esses políticos, será mais fácil para que ambos se beneficiem com os créditos e repercussões de uma obra pública. E, por outro lado, o próprio prefeito ao enviar um projeto para o recebimento de transferências 
voluntárias via convênio pode procurar um deputado a fim de estabelecer uma aliança em que haveria apoio do chefe do Executivo municipal frente ao eleitorado em nome de uma parceria que promovesse também o legislador federal.

Em todas as três diferentes linhas de pesquisa pode-se notar a importância dada às emendas parlamentares. Segundo Pereira e Mueller (2002), a execução das emendas individuais é vista como uma das principais formas disponíveis ao Executivo para negociar suas preferências com sua coalizão no Congresso Nacional. Além disso, esse tipo de emenda é utilizado pelo congresso como uma moeda de troca política de baixo custo.

Contrariando a extrema importância dada às emendas individuais, Figueiredo e Limongi (2002) ressaltam que esse tipo de emenda está longe de ser o meio mais importante de participação do Congresso Nacional no processo orçamentário. Além das emendas individuais, o Congresso pode apresentar outros dois tipos de emendas: as coletivas e as dos relatores. As emendas coletivas podem ser apresentadas por bancadas estaduais e regionais ou por meio de comissões e as emendas dos relatores podem ser de autoria do relator geral ou dos relatores parciais. De acordo com os autores, as emendas individuais também não são privilegiadas pela própria casa legislativa uma vez que, em termos de recursos alocados, as emendas coletivas e as de relatores têm precedência sobre as individuais. Eles concluem que como a definição do volume de recursos para as emendas individuais é uma decisão interna do Poder Legislativo, tal constatação é suficiente para colocar sob suspeição a noção de que o processo orçamentário é orientado exclusivamente para atender aos interesses individuais dos parlamentares.

Neste artigo assume-se a importância e a influência dos partidos em todo o processo orçamentário - tanto no Poder Legislativo, que possui o poder de emendar todos os tipos de convênio públicos, quanto no Poder Executivo, que possui o poder de executar todos e quaisquer convênios públicos (emendados ou não). Dessa forma, testa-se aqui que os convênios firmados entre a União e os municípios são passíveis de influência partidária em todos os âmbitos do governo.

\subsection{Concentração dos votos por partido no Poder Legislativo federal}

Particularmente importante para os interesses das análises econométricas propostas, esta seção discute brevemente a literatura acerca das áreas de influência parlamentar e faz uma análise sobre a geografia do voto partidário do Poder Legislativo federal nos municípios brasileiros. Com o conhecimento das áreas de concentração dos partidos políticos, torna-se 
possível um melhor entendimento das estratégias que os parlamentares adotam sobre suas ações no contexto federativo e, ao relacioná-las com o contexto político, socioeconômico e espacial locais, pretende-se compreender melhor as vias e motivações de distribuição das transferências voluntárias.

Há várias medidas de concentração espacial de votos na literatura. Uma das principais contribuições referentes ao Brasil foram as medidas de concentração propostas por Barry Ames (1995b). O autor traz ao debate a importância de se analisar a distribuição espacial dos votos dos parlamentares para se traçar o seu perfil eleitoral e tentar prever sua atuação no parlamento, estabelecendo de forma mais precisa a conexão eleitoral brasileira. Ele sugere que a concentração de votos dos deputados nos estados toma duas dimensões, ambas baseadas no desempenho municipal do candidato. A primeira dimensão é calculada para cada candidato em cada município como o percentual de votos recebidos pelo candidato em relação ao total de votos no município ponderado pela percentagem do total dos votos do candidato para a qual cada município contribui. Os candidatos com médias ponderadas mais altas tendem a dominar os municípios mais importantes e os candidatos com médias ponderadas mais baixas compartilham os votos desses municípios principais com outros candidatos. Dessa forma, a primeira dimensão diferencia o apoio eleitoral espacial de cada deputado como dominante ou compartilhado. Já a segunda dimensão se refere à distribuição espacial dos municípios como dispersa ou contígua. O cálculo dessa medida utiliza a estatística Moran $\mathrm{I}^{8}$ que calcula a distribuição espacial dos municípios em que o candidato tem bom desempenho.

Pereira e Rennó (2001) contribuem com a medida de concentração/dispersão calculada como a quantidade de votos do candidato que obteve a maior votação no município dividida pelo total de votos que este deputado obteve em todo o estado. De forma parecida, Samuels (2002) utiliza o valor máximo para o percentual de votos do deputado em relação ao total de votos do município. Avelino, Biderman e Silva (2011) trazem uma importante contribuição metodológica sobre a geografia do voto no Brasil para as eleições legislativas. Os autores propõem a utilização de um indicador adaptado da Economia Regional para avaliar a concentração de votos. Segundo os autores, o indicador proposto, denominado G, possibilita avaliar com mais clareza a distribuição de votos dos candidatos no interior de um distrito eleitoral e, consequentemente, aprofundar a compreensão sobre a dinâmica política local.

Silva e Davidian (2013) ampliam as pesquisas anteriores com a adaptação de dois indicadores também baseados em indicadores de economia regional: o Quociente Locacional,

\footnotetext{
${ }^{8} \mathrm{O}$ índice de Moran mede a autocorrelação espacial da votação do candidato em um dado município.
} 
QL, e o Cluster Horizontal, CH. A vantagem dessas medidas está na capacidade de fornecer informações desagregadas sobre a concentração dos votos. O índice QL, inicialmente proposto por Bendavid-Val (1991), mostra a importância relativa de cada município dentro de um setor de atividade, quando pretende-se comparar as proporções de emprego desses setores a fim de determinar se ali há empregos em número acima do esperado para o tamanho da cidade em questão. O QL adaptado para a Economia Política (utilizado por Silva \& Davidian (2013)) pretende medir a concentração dos votos recebidos pelo deputado em cada município, controlando-se pelo tamanho relativo dos municípios dentro de seu respectivo estado. Dessa forma, o índice pretende avaliar em quantos municípios o deputado concentrou os seus votos e será medido da seguinte forma:

$$
Q L_{i j}=\frac{V_{i j}}{V_{i}} / \frac{V_{j}}{V}
$$

Sendo $V_{i j}=\sum_{i j} V_{i j}$ o total de votos do partido $i$ no município $j, V_{j}=\sum_{i} V_{i j}$ o total de votos no município $j, V_{i}=\sum_{j} V_{i j}$ o total de votos do partido $i$ e $V=\sum_{j} \sum_{i} V_{i j}$ o total de votos na região toda (estado ou microrregião). Dessa forma, considerando uma distribuição homogênea, este indicador permite a comparação dos votos obtidos por município em termos relativos (SILVA \& DAVIDIAN, 2013). Por exemplo, se a alocação espacial dos votos de todos os candidatos fosse homogeneamente distribuída, uma cidade com $1 \%$ do total dos eleitores do estado deveria contribuir com $1 \%$ dos votos para todos os candidatos em dada eleição; considera-se que se um deputado receber 10.000 votos, $1 \%$ (100 votos) desses votos seria proveniente daquele município. Isto implica em um Quociente Locacional igual a 1 (um). Caso o deputado tenha recebido 450 votos naquela cidade, o QL indicará 4,5, já que ele recebeu 4,5 vezes o número de votos esperado em uma distribuição homogênea. No entanto, apesar de este índice mensurar apropriadamente o nível de concentração de votos por candidato e por município, ele não permite inferir diretamente se o candidato tem votação mais ou menos concentrada no município, isto é, apenas permite analisar qual a relação entre os votos esperados e os votos recebidos por cada candidato em cada um dos municípios isoladamente.

Para se analisar o nível de competição política em um dado município, Taagepera (1979) propõe um indicador de desequilíbrio eleitoral que reflete o desequilíbrio das disputas eleitorais em cada cidade:

$$
T_{m}=\frac{\sum_{i=1}^{\infty}\left[\frac{\left(P_{i, m}-P_{i+1, m}\right)}{i}\right]-H_{m}^{2}}{\sqrt{H_{m}}-H_{m}^{2}}
$$


$T_{m}$ é o índice de desequilíbrio para a cidade $m, P_{i, m}$ é o percentual de votos do $i$-ésimo candidato na cidade $m$ e $H_{m}$ é o índice de Herfindahl-Hirschman ${ }^{9}$ na cidade $m$. Esse índice será incluído na fórmula do índice de desequilíbrio como uma forma de eliminar a "correlação residual" com o próprio termo $H$, já que o somatório do numerador varia entre os limites de $\sqrt{H}$ a $H^{2}$.

Este indicador pretende mostrar quão disputada é a eleição em um município a partir da ideia de desequilíbrio. Neste contexto, quanto mais desequilibrada for uma votação, menos acirrada será, pois, afinal, um dos candidatos tende a desequilibrar a votação em seu favor. Nota-se que os valores de $T_{m}$ pertencem ao intervalo $[0,1]$ e quanto mais próximo de 1 (um), mais desequilibrada é a distribuição de votos naquele município ( menos acirrada será a votação no município).

\subsubsection{Medidas de concentração para os municípios brasileiros para as eleições federais de 2006 e 2010}

Nesta seção pretende-se fazer algumas análises espaciais sobre as áreas de influência dos partidos do Legislativo federal. Para isso, calculou-se os índices o Quociente Locacional, QL, e índice de desequilíbrio para a cidade $m, T_{m}$, para cada um dos partidos para as eleições federais de 2006 e 2010. Considerou-se todos os votos direcionados para um determinado partido, seja para a legenda ou para um candidato específico. A Tabela 2.2 mostra o índice QL para os quatro partidos com os maiores valores para esse índice, sejam eles: PMDB, PP, PSDB e PT.

Tabela 2.2 - Indicador Quociente Locacional para o Poder Legislativo federal - 2006/2010

\begin{tabular}{|c|c|c|c|c|}
\hline \multirow[b]{2}{*}{ Partidos } & \multicolumn{2}{|c|}{2006} & \multicolumn{2}{|c|}{2010} \\
\hline & Média & Desvio Padrão & Média & Desvio Padrão \\
\hline PMDB & 3.904828 & 5.010828 & 4.121865 & 7.079895 \\
\hline $\mathrm{PP}$ & 3.340887 & 6.456267 & 3.427846 & 5.370427 \\
\hline PSDB & 3.688839 & 5.471368 & 2.742224 & 4.151753 \\
\hline PT & 2.813002 & 3.518938 & 2.631140 & 2.953016 \\
\hline
\end{tabular}

Fonte: Tribunal Superior Eleitoral. Tabela elaborada pela autora.

Nota-se que os partidos apresentam concentração de votos um pouco distintas entre 2006 e 2010. Os partidos PMDB e PP, em média, aumentaram suas áreas de influência política e os

\footnotetext{
${ }^{9} \mathrm{O}$ índice de Herfindahl-Hirschman neste contexto será calculado da seguinte forma: $H_{m}=\frac{\sum_{i} V^{2}{ }_{i, m}}{\left(\sum_{i} V_{i, m}\right)^{2}}$, em que $V_{i, m}$ é o número de votos recebidos pelo candidato i no município m.
} 
partidos PSDB e PT, em média, diminuíram seu poder em algumas localidades. O PT apresenta um decaimento no seu indicador de influência política e isso pode ser observado na Figura 2.1. Percebe-se, visualmente, que o PT perdeu bastante espaço no oeste brasileiro mas aumentou um pouco sua influência no Rio Grande do Sul.

Figura 2.1 - Área de influência política do PT de acordo com o indicador Quociente Locacional - 2006/2010
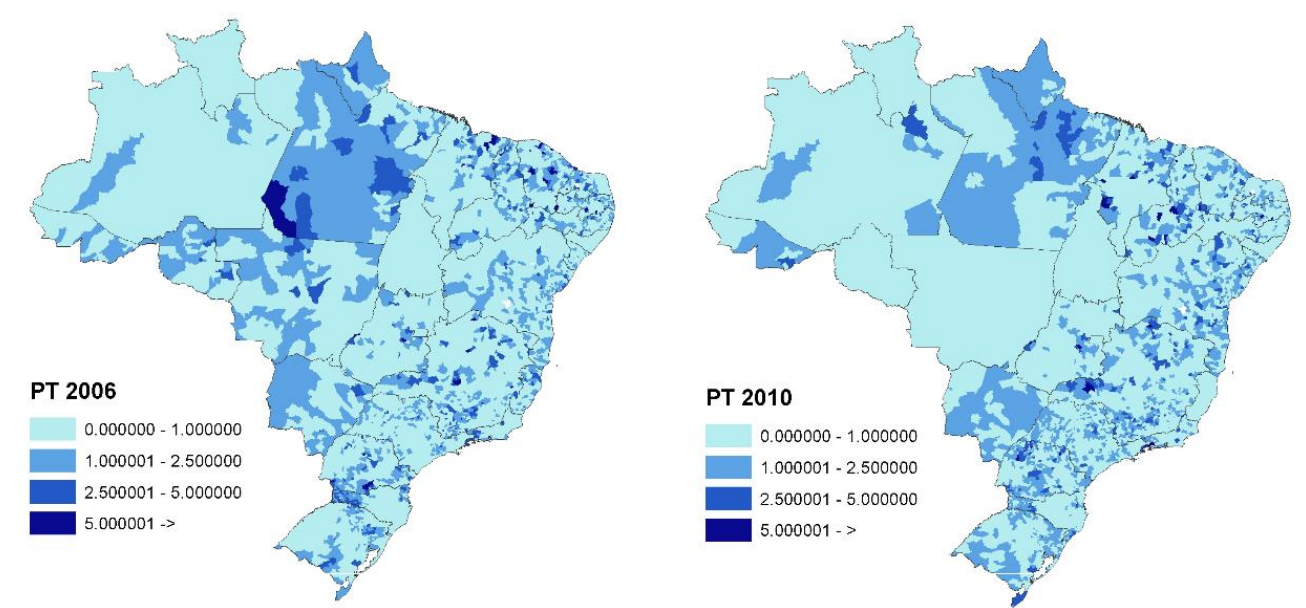

Fonte: Tribunal Superior Eleitoral (2016). Gráfico elaborado pela autora.

O PSDB perdeu grande parte de sua influência política ao compararmos as duas eleições - de 3,68 para 2,70. Pode-se perceber pela Figura 2.2 que o partido perdeu influência em grande parte de seus municípios sobre os quais exercia forte poder $(\mathrm{QL}>5)$. Além disso, nota-se a o enfraquecimento em todo o Nordeste e Mato Grosso do Sul.

Figura 2.2 - Área de influência política do PSDB de acordo com o indicador Quociente Locacional - 2006/2010
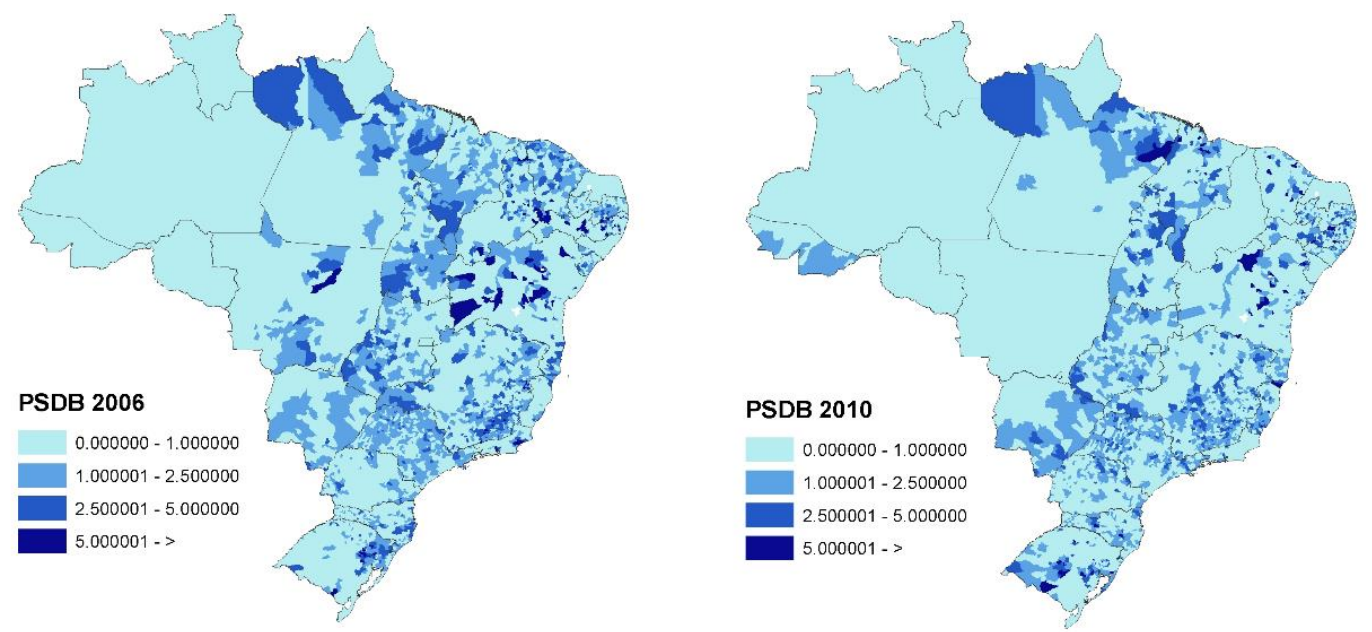

Fonte: Tribunal Superior Eleitoral (2016). Gráfico elaborado pela autora. 
O PMDB saiu de um Quociente Locacional igual a 3,90 para 4,12. Na Figura 2.3 podese perceber que o partido ganhou muita influência em Mato Grosso. Pode-se inferir dessas figuras que a área migrou de uma influência do PSDB e PT em 2006 para o poder do PMDB em 2010.

Figura 2.3 - Área de influência política do PMDB de acordo com o indicador Quociente Locacional - 2006/2010
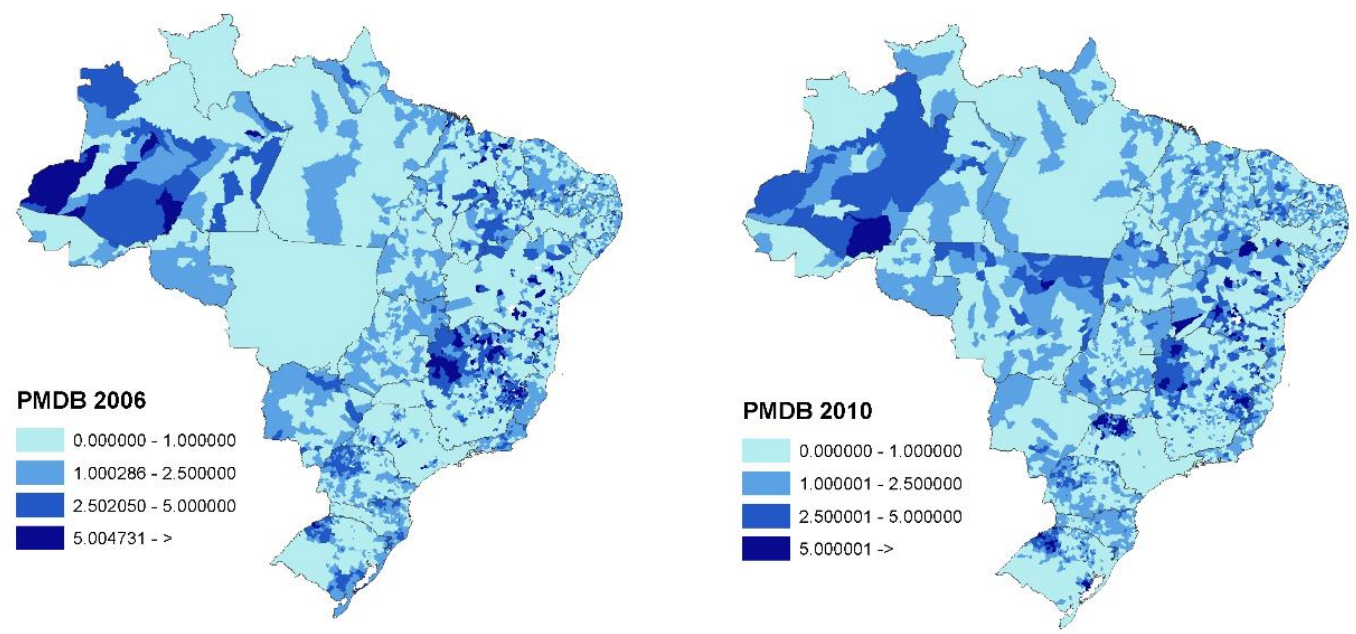

Fonte: Tribunal Superior Eleitoral (2016). Gráfico elaborado pela autora.

Já o PP praticamente manteve o mesmo índice. Mas, pode-se notar uma pequena migração de suas áreas de influência nesses dois anos eleitorais.

Figura 2.4 - Área de influência política do PP de acordo com o indicador Quociente Locacional - 2006/2010
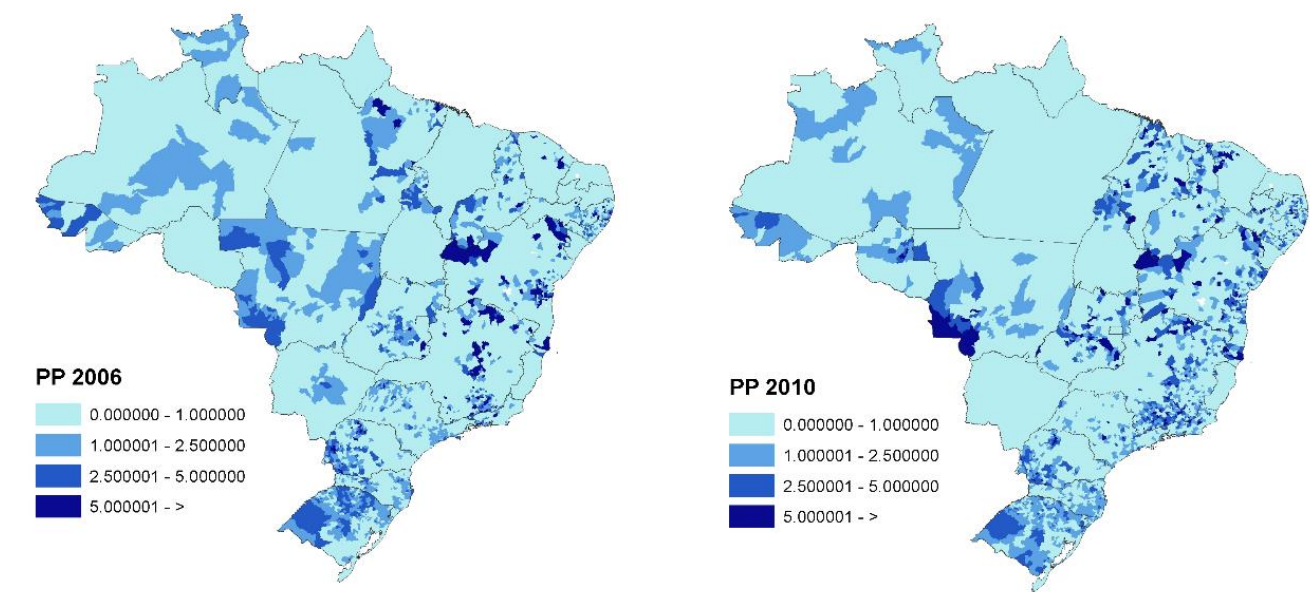

Fonte: Tribunal Superior Eleitoral (2016). Gráfico elaborado pela autora.

A Figura 2.5 mostra o índice de Taagepera para os municípios brasileiros com os resultados das eleições para deputado federal dos anos de 2006 e 2010. A análise pretende 
apenas dar uma noção visual sobre as distribuições das votações dos partidos que disputam cadeiras para a Câmara Federal - quanto mais escura a área, menos acirrada foi a votação no município em questão, isto é, existe um partido que está desequilibrando a votação em seu favor. Poucas áreas foram muito disputadas pelos deputados nas duas eleições; então, pode-se inferir que em grande parte dos municípios existe a influência política de alguns partidos.

Figura 2.5 - Índice de Taagepera para eleições legislativas - 2006/2010

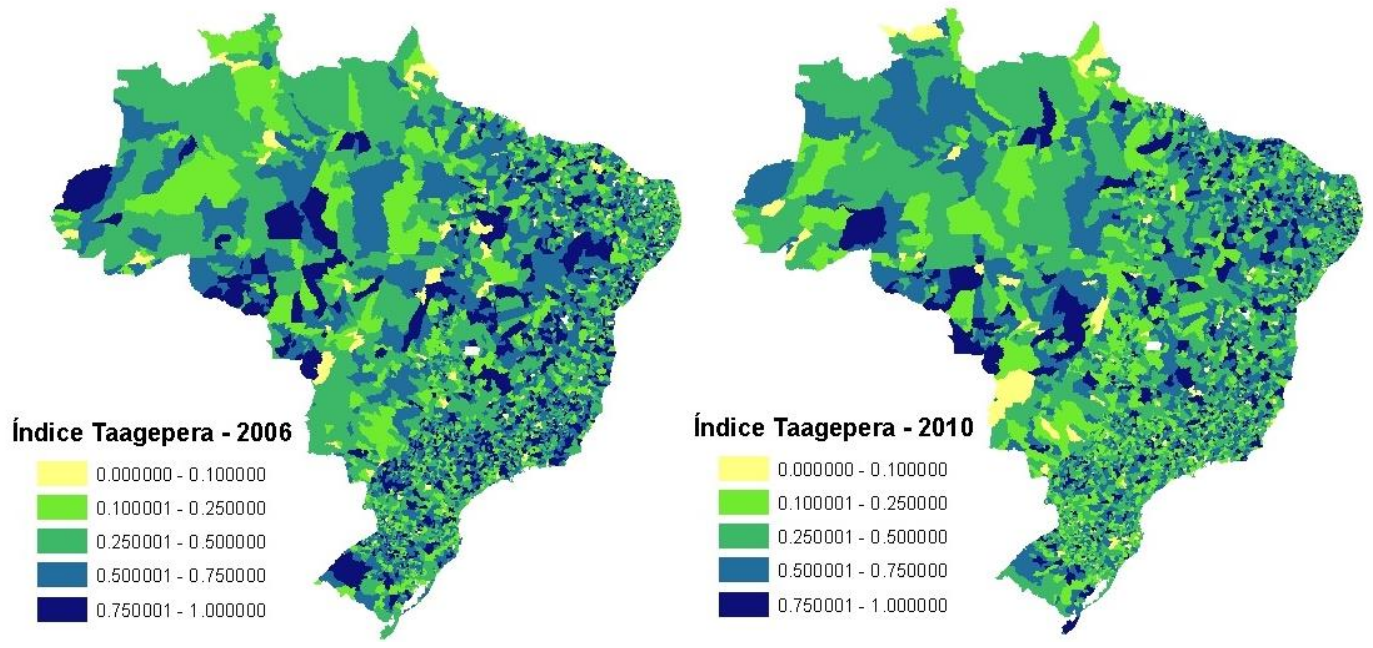

Fonte: Tribunal Superior Eleitoral (2016). Gráfico elaborado pela autora.

\subsection{Análise econométrica}

Com o intuito de estudar as influências políticas sofridas pela política fiscal municipal, este trabalho pretende analisar empiricamente os efeitos da identidade partidária entre os entes governamentais e legisladores na distribuição de rendas via transferências voluntárias, por meio de convênios públicos e contratos de repasses federais, para os municípios.

Além de envolverem diferentes atores políticos com diferentes interesses, os programas e ações do governo federal possuem diferentes critérios técnicos para a priorização da aplicação dos recursos discricionários. Muitas vezes o nível de desenvolvimento socioeconômico local, as regras e limites impostos pelas instituições orçamentárias, dentre outros motivos, são levados em conta para a efetivação dos convênios e contratos de repasse. Por isso, além da análise principal, pretende-se verificar se essas transferências são influenciadas por outras condições políticas do ente, pelas características sociais dos municípios, pelas regras institucionais impostas ao recebimento dessas verbas e pelas características pessoais dos prefeitos.

Com este objetivo, foram aplicadas técnicas tradicionais de dados em painel e de regressão quantílica em um painel de dados para os anos de 2001 a 2012. As medidas de 
identidade partidária foram construídas para os vários níveis de governo e dadas pelas seguintes fórmulas:

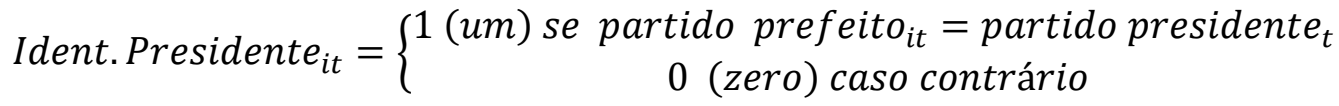

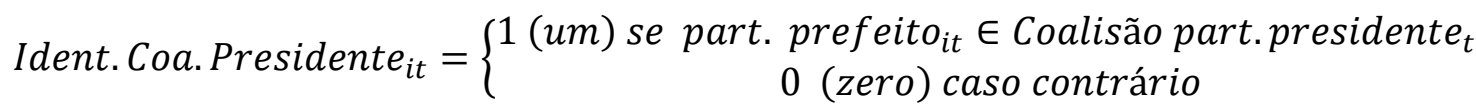

A fórmula Ident. Presidente $e_{i t}$ será igual a 1 (um) se o partido do prefeito do município $i$ no ano $t$ for igual ao partido do presidente no ano $t$. Da mesma forma, Ident.Coa.Presidente $i t$ será 1 (um) se o partido do prefeito do município $i$ no ano $t$ pertencer à coalizão do partido do presidente no ano $t$. A dummy que representa os governos estaduais segue a mesma lógica das duas variáveis para presidente e então cria-se: Ident.Governador ${ }_{i t .}$.

A partir do Quociente Locacional (1), constrói-se a variável referente à igualdade partidária entre o Poder Executivo do município $i$ no tempo $t$ e o Poder Legislativo federal no tempo $t$.

A variável (3) refere-se à identidade partidária entre o Poder Executivo municipal e o Poder Legislativo federal.

$$
\text { Id. } \operatorname{Leg}_{i t}=\left\{\begin{array}{c}
1\left(\text { um) se partido prefeito } \text { p }_{i}=j \text { e } Q L_{i j}>1\right. \\
0 \text { (zero) caso contrário }
\end{array}\right.
$$

A variável $I d . \operatorname{Leg}_{i t}$ será igual a 1 (um) se o partido gestor do município $i$ for igual ao partido $j$ que tenha um Quociente Locacional no município $i$ maior do que um. Isto significa que haverá uma identidade partidária se o município pertencer a uma área de concentração de votos de um dado partido e o prefeito deste município pertencer ao partido em questão.

Espera-se que todas essas variáveis de interesse apresentem um efeito positivo sobre as transferências voluntárias indicando a existência de viés político na distribuição de recursos via convênios. A Tabela 2.3 resume todas as variáveis de controle utilizadas nos testes empíricos. ${ }^{10}$

\footnotetext{
${ }^{10}$ Uma descrição mais completa, além de suas fórmulas vide o ensaio 1.
} 
Tabela 2.3 - Descrição das variáveis de controle e suas estatísticas descritivas

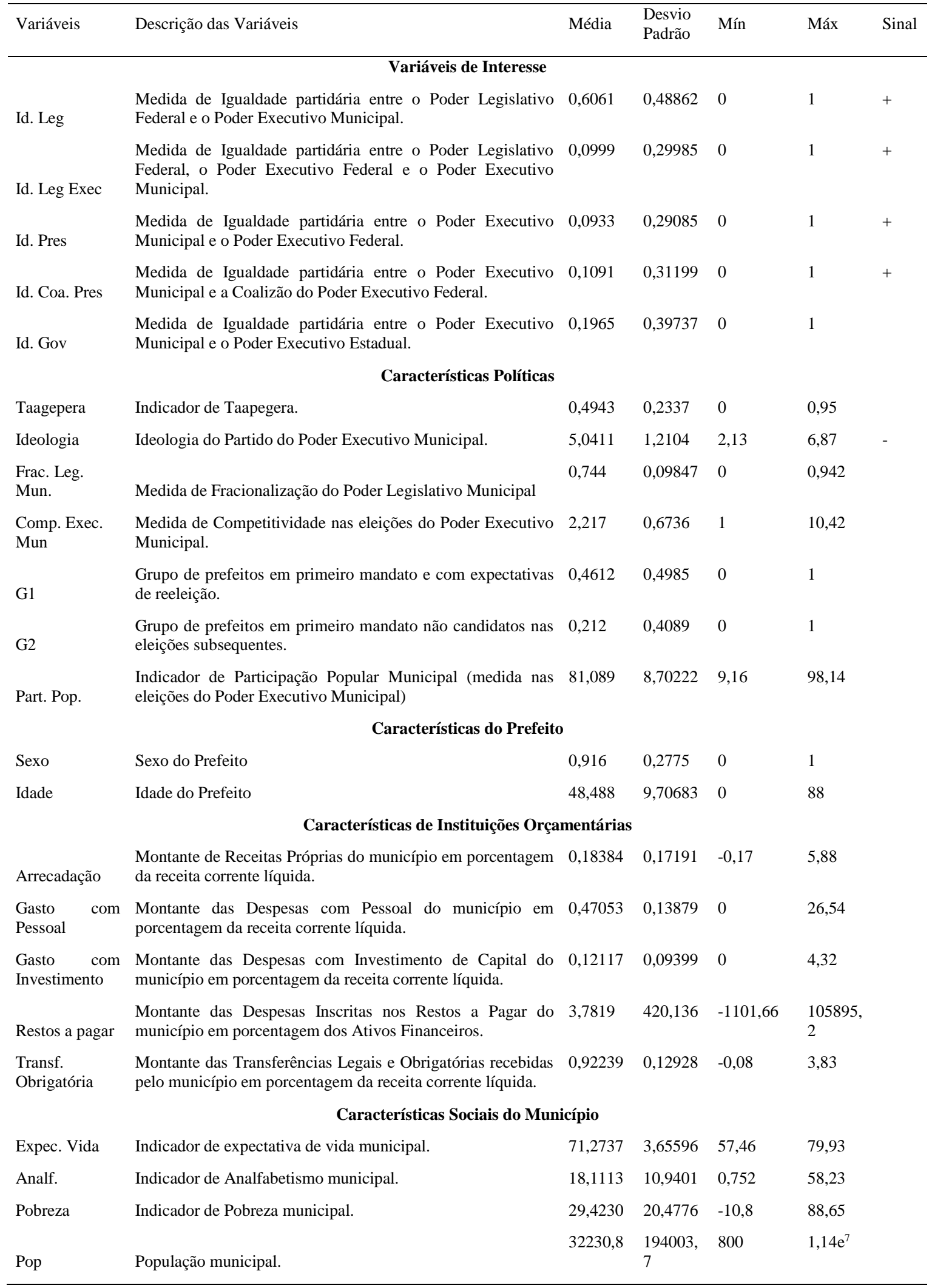

Fonte: Elaborado pela autora. 


\subsection{Resultados empíricos}

Os métodos em painel foram escolhidos com o intuito de avaliar o desempenho real dos indicadores de transferências de renda ao longo do tempo. Uma das grandes vantagens dessa metodologia é o controle da endogeneidade decorrente de variáveis omitidas (relacionadas com os eleitores ou com as localidades) fixas no tempo e correlacionadas com os regressores. Podem-se citar como exemplos, algumas características institucionais do município que podem estar correlacionadas tanto com uma maior arrecadação dos recursos voluntários quanto com os índices sociais.

O modelo considera quatro variáveis de identidade partidária:

$$
\begin{aligned}
\text { Convênio }_{i t}= & \alpha_{0}+\alpha_{1} \text { Id. }_{\text {Leg }}+\alpha_{2} \text { Id.Pres }_{i t}+\alpha_{3} \text { Id.Gov }_{i t}+\alpha_{4} \text { Id.Coa.Pres }_{i t} \\
& +\beta \text { Fatores Políticos } \\
& +\sigma \text { Características Pessoais }+ \text { Instituições Orçamentárias }_{i t}+\pi \text { Fatores Sociais } \\
& +\rho
\end{aligned}
$$

A variável de interesse utilizada, Id. Legislativo $_{i t}$, será dada por pela fórmula (3). Nesta análise a identidade partidária será medida entre os partidos do Poder Executivo municipal e federal e o Poder Legislativo federal. A variável dependente Convênio ${ }_{i t}$ será dada por sete

\begin{tabular}{|c|c|c|c|}
\hline Testes & \multicolumn{2}{|c|}{ Variável Dependente } & Descrição da Variável Dependente \\
\hline 1 & $\begin{array}{l}\text { Valor } \\
\text { Global }\end{array}$ & Convênios Totais & $\begin{array}{l}\text { Razão entre o Montante total dos convênios pela receita corrente } \\
\text { líquida. }\end{array}$ \\
\hline 2 & MS & $\begin{array}{l}\text { Convênios } \\
\text { Ministério da } \\
\text { Saúde }\end{array}$ & $\begin{array}{l}\text { Razão entre o montante total dos convênios e contratos de repasse } \\
\text { firmado via Ministério da Saúde em porcentagem da receita corrente } \\
\text { líquida municipal. }\end{array}$ \\
\hline 3 & MEC & $\begin{array}{l}\text { Convênios } \\
\text { Ministério da } \\
\text { Educação }\end{array}$ & $\begin{array}{l}\text { Razão entre o montante total dos convênios e contratos de repasse } \\
\text { firmado via Ministério da Educação e em porcentagem da receita } \\
\text { corrente líquida municipal. }\end{array}$ \\
\hline 4 & MDS & $\begin{array}{l}\text { Convênios } \\
\text { Ministério do } \\
\text { Desenvolvimento } \\
\text { Social }\end{array}$ & $\begin{array}{l}\text { Razão entre o montante total dos convênios e contratos de repasse } \\
\text { firmado via MDS em porcentagem da receita corrente líquida } \\
\text { municipal. }\end{array}$ \\
\hline 5 & Cidades & $\begin{array}{l}\text { Convênios } \\
\text { Ministério das } \\
\text { Cidades }\end{array}$ & $\begin{array}{l}\text { Razão entre o montante total dos convênios e contratos de repasse } \\
\text { firmado via Ministério das Cidades em porcentagem da receita } \\
\text { corrente líquida municipal. }\end{array}$ \\
\hline 6 & MI & $\begin{array}{l}\text { Convênios } \\
\text { Ministério da } \\
\text { Integração Social }\end{array}$ & $\begin{array}{l}\text { Razão entre o montante total dos convênios e contratos de repasse } \\
\text { firmado via Ministério da Integração Social em porcentagem da } \\
\text { receita corrente líquida municipal. }\end{array}$ \\
\hline
\end{tabular}
medidas diferentes que estão expressas na Quadro 2.1.

Tabela 2.1 - Descrições variáveis dependentes 
Com base na aplicação dos métodos de Hausmann e Chow ${ }^{11}$, optou-se pela análise de efeitos fixos. Os resultados para o modelo de dados em painel com efeitos fixos para os seis testes descritos acima estão dispostos na Tabela 2.4. De acordo com esses resultados, o efeito da identidade partidária entre o Poder Legislativo federal e o Poder Executivo municipal no montante total conveniado aponta para recebimentos de transferências voluntárias em média superiores aos municípios que não possuem essa identidade. Em média, essa identidade partidária resulta em um aumento de $0,326 \%$ do montante total de convênios em porcentagem da receita corrente líquida municipal. Esta é uma contribuição original da presente pesquisa que reforça a tese de que os partidos políticos desempenham importante papel no direcionamento das transferências voluntárias da União para os municípios. Mais ainda, sugere que a importante característica partidária na definição de quem recebe transferências voluntárias no Brasil, identificada em Ferreira e Bugarin $(2005,2007)$ para a identificação partidária entre prefeito e presidente, também se reflete no que diz respeito à identificação partidária entre prefeito e legislador. Esse resultado mostra um importante papel do legislativo na determinação das políticas públicas subnacionais, conforme sugere a literatura discutida no início do capítulo.

No entanto, esse efeito é muito mais forte quando o prefeito pertence ao mesmo partido que o presidente da República, em média, 1,19\% da receita corrente líquida. Esse resultado sugere que, ainda que tenhamos identificado pela primeira vez o papel significativo do Legislativo no direcionamento dos convênios com os municípios, o Executivo nacional ainda exerce papel prevalente sobre esse direcionamento.

Reforçando o resultado encontrado acima, as duas medidas de identidade partidária apresentam um efeito positivo e significante nos convênios firmados entre prefeituras e os Ministérios da Saúde e das Cidades.

Estes resultados corroboram os estudos de Ferreira e Bugarin $(2005,2007)$ que sugerem que as transferências voluntárias intergovenamentais no Brasil são significativamente influenciadas por motivações político-partidárias. De acordo com os mesmos autores, o governo federal tem um compromisso natural com seu próprio partido e uma forma de recompensar aqueles que o apoiaram durante o processo eleitoral seria conduzindo recursos públicos cuja aplicação é discricionária do governo federal para localidades da base governista (FERREIRA \& BUGARIN, 2005; 2007).

Parte relevante dos recursos destinados às políticas gerenciadas pelo Ministério da Integração Nacional tem como forma de repasse os Fundos Constitucionais de Financiamento,

\footnotetext{
${ }^{11}$ Resultados dos testes estão no anexo B.
} 
os Fundos Constitucionais de Financiamento do Centro-Oeste (FCO), do Nordeste (FNE) e do Norte (FNO). Esses fundos, assim como os convênios, são passíveis de influência política (MENDES, MIRANDA \& COSIO, 2008) e o alinhamento partidário com o governo federal pode facilitar seu recebimento. $\mathrm{O}$ fato de haver a possibilidade de maiores aportes financeiros repassados por outros meios, distintos dos convênios, os quais também são passíveis de influência política, poderia justificar a falta de significância no recebimento de convênios do Ministério da Integração Nacional (MI) perante o alinhamento partidário entre a prefeitura e os dois poderes federais (Legislativo e Executivo) e, além disso, o efeito negativo para o alinhamento entre prefeito e a coalizão do presidente da República.

O caso das transferências provenientes do Ministério da Educação, o qual tem um efeito insignificante para a identidade com o Legislativo federal, um efeito de, em média, $-0,05 \%$ de transferências em porcentagem do Produto Interno Bruto perante a identidade partidária entre prefeitos e presidente e um efeito de $-0,097 \%$ para a identidade entre prefeito e a coalizão do presidente, pode ser explicado pelo mesmo argumento utilizado para o MI. ${ }^{12}$

$\mathrm{O}$ indicador de Taagepera apresenta um efeito positivo no montante total de convênios firmados de, em média, $0,51 \%$ da receita corrente líquida municipal. Este resultado mostra que quanto mais acirrada é a disputa partidária (medida para as eleições de deputados federais) em um município, maior é o aporte de transferências via convênios públicos. Esse resultado sugere que o Poder Legislativo federal tende a alocar mais recursos nas regiões em que existe a predominância de eleitores indecisos (swing voters) no que se refere às eleições para o Legislativo. No entanto, pode-se observar um resultado contrário para o indicador de competitividade no executivo local, o qual apresenta um efeito negativo no montante total de transferências de, em média, - $-0,158 \%$ em porcentagem da receita corrente líquida. Quanto mais competitivas são as eleições municipais para o cargo do executivo, menores são os recebimentos de transferências voluntárias.

Esferas superiores de governo podem montar estratégias com os governos locais com fins eleitorais. Uma das estratégias é buscar apoio em regiões em que os parceiros e eleitores estão a favor do governante, chamada de "core constituency hypothesis" (COX \& MCCUBBINS, 1986, ou buscar apoio em regiões onde os parceiros não lhe são favoráveis e os eleitores são indecisos, chamada de "swing constituency hypothesis" (DIXIT \& LONDREGAN, 1996).

12 Vide a esse respeito, Bugarin e Marciniuk (2016). 
Tabela 2.4 - Resultados das estimações para dados em painel efeito fixo para o modelo 1

\begin{tabular}{|c|c|c|c|c|c|c|}
\hline Variáveis & $\begin{array}{c}\text { (Teste } 1) \\
\text { Total de Convênios }\end{array}$ & $\begin{array}{c}\text { (Teste 2) } \\
\text { MS }\end{array}$ & $\begin{array}{l}\text { (Teste 3) } \\
\text { MEC }\end{array}$ & $\begin{array}{l}\text { (Teste 4) } \\
\text { Cidades }\end{array}$ & $\begin{array}{l}\text { (Teste 5) } \\
\text { MDS }\end{array}$ & $\begin{array}{c}\text { (Teste 6) } \\
\text { MI }\end{array}$ \\
\hline Id. Leg & $\begin{array}{l}0,00326 * * * \\
(0,00110)\end{array}$ & $\begin{array}{l}0,00136^{* *} \\
(0,000563)\end{array}$ & $\begin{array}{l}0,000127 \\
(0,000227)\end{array}$ & $\begin{array}{l}0,000795^{*} \\
(0,000447)\end{array}$ & $\begin{array}{l}3,63 e-05 \\
(9,79 e-05)\end{array}$ & $\begin{array}{l}0,000284 \\
(0,000360)\end{array}$ \\
\hline Id. Pres & $\begin{array}{l}0,0119 * * * \\
(0,00212)\end{array}$ & $\begin{array}{l}0,00579 * * * \\
(0,00114)\end{array}$ & $\begin{array}{l}-0,000543^{*} \\
(0,000279)\end{array}$ & $\begin{array}{l}0,00215 * * * \\
(0,000612)\end{array}$ & $\begin{array}{l}0,00105 * * * \\
(0,000279)\end{array}$ & $\begin{array}{l}-2,82 \mathrm{e}-05 \\
(0,00102)\end{array}$ \\
\hline Id.Coa Pres & $\begin{array}{l}-0,0249 * * * \\
(0,00170)\end{array}$ & $\begin{array}{l}0,00171^{*} \\
(0,000906)\end{array}$ & $\begin{array}{l}-0,00973 * * * \\
(0,000372)\end{array}$ & $\begin{array}{l}-0,00442 * * * \\
(0,000504)\end{array}$ & $\begin{array}{l}5,60 \mathrm{e}-05 \\
(0,000162)\end{array}$ & $\begin{array}{l}-0,00316^{* * * *} \\
(0,00101)\end{array}$ \\
\hline Id. Gov & $\begin{array}{l}-0,00756^{* * * *} \\
(0,00101)\end{array}$ & $\begin{array}{l}-0,000961 * \\
(0,000550)\end{array}$ & $\begin{array}{l}-0,000737 * * * \\
(0,000241)\end{array}$ & $\begin{array}{l}-0,00210 * * * \\
(0,000359)\end{array}$ & $\begin{array}{l}-0,000286^{* * * *} \\
(8,73 \mathrm{e}-05)\end{array}$ & $\begin{array}{l}-0,000556 \\
(0,000349)\end{array}$ \\
\hline Taagepera & $\begin{array}{l}0,00512 * * \\
(0,00221)\end{array}$ & $\begin{array}{l}0,000641 \\
(0,00111)\end{array}$ & $\begin{array}{l}0,000856^{*} \\
(0,000464)\end{array}$ & $\begin{array}{l}0,000669 \\
(0,000785)\end{array}$ & $\begin{array}{l}2,57 \mathrm{e}-05 \\
(0,000186)\end{array}$ & $\begin{array}{l}0,000839 \\
(0,000883)\end{array}$ \\
\hline Ideologia & $\begin{array}{l}-0,00274 * * * \\
(0,000574)\end{array}$ & $\begin{array}{l}-0,000407 \\
(0,000296)\end{array}$ & $\begin{array}{l}-0,00106^{* * * *} \\
(0,000109)\end{array}$ & $\begin{array}{l}-0,000427 * * \\
(0,000185)\end{array}$ & $\begin{array}{l}3,64 \mathrm{e}-05 \\
(5,31 \mathrm{e}-05)\end{array}$ & $\begin{array}{l}-0,000249 \\
(0,000268)\end{array}$ \\
\hline Frac. Leg Mun. & $\begin{array}{l}0,0150 * \\
(0,00779)\end{array}$ & $\begin{array}{l}0,00178 \\
(0,00435)\end{array}$ & $\begin{array}{l}0,00423 * * \\
(0,00184)\end{array}$ & $\begin{array}{l}0,000389 \\
(0,00256)\end{array}$ & $\begin{array}{l}-0,00135^{*} \\
(0,000816)\end{array}$ & $\begin{array}{l}0,00400 \\
(0,00308)\end{array}$ \\
\hline Comp. Exec. Mun & $\begin{array}{l}-0,00153 * \\
(0,000929)\end{array}$ & $\begin{array}{l}0,000267 \\
(0,000443)\end{array}$ & $\begin{array}{l}-0,000314 * \\
(0,000173)\end{array}$ & $\begin{array}{l}-0,000194 \\
(0,000330)\end{array}$ & $\begin{array}{l}-7,17 \mathrm{e}-05 \\
(8,86 \mathrm{e}-05)\end{array}$ & $\begin{array}{l}-0,000647 * \\
(0,000368)\end{array}$ \\
\hline G1 & $\begin{array}{l}0,00891 * * * \\
(0,00103)\end{array}$ & $\begin{array}{l}0,00331 * * * \\
(0,000480)\end{array}$ & $\begin{array}{l}0,000456 * * \\
(0,000229)\end{array}$ & $\begin{array}{l}0,00240 * * * \\
(0,000326)\end{array}$ & $\begin{array}{l}0,000300 * * * \\
(9,96 \mathrm{e}-05)\end{array}$ & $\begin{array}{l}6,31 \mathrm{e}-05 \\
(0,000465)\end{array}$ \\
\hline $\mathrm{G} 2$ & $\begin{array}{l}-0,00431 * * \\
(0,00183)\end{array}$ & $\begin{array}{l}-0,000266 \\
(0,000767)\end{array}$ & $\begin{array}{l}-0,000704 * * \\
(0,000310)\end{array}$ & $\begin{array}{l}-0,000761 \\
(0,000552)\end{array}$ & $\begin{array}{l}0,000218^{*} \\
(0,000113)\end{array}$ & $\begin{array}{l}-0,000944 \\
(0,000906)\end{array}$ \\
\hline Part. Pop. & $\begin{array}{l}9,72 \mathrm{e}-05 \\
(8,59 \mathrm{e}-05)\end{array}$ & $\begin{array}{l}4,22 \mathrm{e}-05 \\
(4,10 \mathrm{e}-05)\end{array}$ & $\begin{array}{l}2,97 \mathrm{e}-05 \\
(1,83 \mathrm{e}-05)\end{array}$ & $\begin{array}{l}5,09 \mathrm{e}-05^{*} \\
(2,82 \mathrm{e}-05)\end{array}$ & $\begin{array}{l}-1,31 \mathrm{e}-05^{*} \\
(6,76 \mathrm{e}-06)\end{array}$ & $\begin{array}{l}-3,33 \mathrm{e}-05 \\
(3,09 \mathrm{e}-05)\end{array}$ \\
\hline Sexo & $\begin{array}{l}-0,00132 \\
(0,00277)\end{array}$ & $\begin{array}{l}-5,82 \mathrm{e}-05 \\
(0,00150)\end{array}$ & $\begin{array}{l}5,43 \mathrm{e}-06 \\
(0,000685)\end{array}$ & $\begin{array}{l}0,000645 \\
(0,000912)\end{array}$ & $\begin{array}{l}0,000273 \\
(0,000300)\end{array}$ & $\begin{array}{l}-0,00111 \\
(0,000879)\end{array}$ \\
\hline Idade & $\begin{array}{l}-0,000202 * * * \\
(7,46 \mathrm{e}-05)\end{array}$ & $\begin{array}{l}8,72 \mathrm{e}-06 \\
(4,39 \mathrm{e}-05)\end{array}$ & $\begin{array}{l}-1,59 \mathrm{e}-05 \\
(2,07 \mathrm{e}-05)\end{array}$ & $\begin{array}{l}-4,83 \mathrm{e}-05^{* *} \\
(2,29 \mathrm{e}-05)\end{array}$ & $\begin{array}{l}1,92 \mathrm{e}-06 \\
(6,56 \mathrm{e}-06)\end{array}$ & $\begin{array}{l}-2,39 \mathrm{e}-05 \\
(3,10 \mathrm{e}-05)\end{array}$ \\
\hline Arrecadação & $\begin{array}{l}0,0734 * * * \\
(0,0122)\end{array}$ & $\begin{array}{l}0,0150 * * * \\
(0,00340)\end{array}$ & $\begin{array}{l}0,00715^{* * * *} \\
(0,00122)\end{array}$ & $\begin{array}{l}0,00777 * * * \\
(0,00245)\end{array}$ & $\begin{array}{l}0,000861 \\
(0,000727)\end{array}$ & $\begin{array}{l}0,0251 * * * \\
(0,00842)\end{array}$ \\
\hline Pessoal & $\begin{array}{l}0,0166 * * \\
(0,00751)\end{array}$ & $\begin{array}{l}0,00187 \\
(0,00155)\end{array}$ & $\begin{array}{l}0,0108 * * * \\
(0,00156)\end{array}$ & $\begin{array}{l}0,00215^{* *} \\
(0,000999)\end{array}$ & $\begin{array}{l}0,000692 * \\
(0,000379)\end{array}$ & $\begin{array}{l}6,54 \mathrm{e}-05 \\
(0,00284)\end{array}$ \\
\hline Investimento & $\begin{array}{l}0,0214 \\
(0,0155)\end{array}$ & $\begin{array}{l}0,00210 \\
(0,00479)\end{array}$ & $\begin{array}{l}-0,00332 * * \\
(0,00163)\end{array}$ & $\begin{array}{l}-0,00499 \\
(0,00311)\end{array}$ & $\begin{array}{l}-0,00122 * * \\
(0,000529)\end{array}$ & $\begin{array}{l}0,0258 * * \\
(0,0118)\end{array}$ \\
\hline Restos & $\begin{array}{l}2,24 \mathrm{e}-07 * * * \\
(3,65 \mathrm{e}-08)\end{array}$ & $\begin{array}{l}-6,92 \mathrm{e}-08 * * * \\
(1,91 \mathrm{e}-08)\end{array}$ & $\begin{array}{l}-3,18 \mathrm{e}-08 * * \\
(1,38 \mathrm{e}-08)\end{array}$ & $\begin{array}{l}1,35 \mathrm{e}-07 * * * \\
(8,78 \mathrm{e}-09)\end{array}$ & $\begin{array}{l}1,02 \mathrm{e}-07 * * * \\
(2,84 \mathrm{e}-09)\end{array}$ & $\begin{array}{l}6,74 \mathrm{e}-09 \\
(1,41 \mathrm{e}-08)\end{array}$ \\
\hline Obrigatórias & $\begin{array}{l}0,183 * * * \\
(0,0247)\end{array}$ & $\begin{array}{l}0,0369 * * * \\
(0,00601)\end{array}$ & $\begin{array}{l}0,0125 * * * \\
(0,00186)\end{array}$ & $\begin{array}{l}0,0236 * * * \\
(0,00410)\end{array}$ & $\begin{array}{l}0,00305 * * * \\
(0,000551)\end{array}$ & $\begin{array}{l}0,0526 * * * \\
(0,0187)\end{array}$ \\
\hline Expect. Vida & $\begin{array}{l}-0,00337 * * * \\
(0,000764)\end{array}$ & $\begin{array}{l}-0,00148 * * * \\
(0,000390)\end{array}$ & $\begin{array}{l}0,000256^{* * *} \\
(0,000118)\end{array}$ & $\begin{array}{l}-0,000766^{* * * *} \\
(0,000203)\end{array}$ & $\begin{array}{l}5,23 \mathrm{e}-05 \\
(5,69 \mathrm{e}-05)\end{array}$ & $\begin{array}{l}-0,000794 * * \\
(0,000326)\end{array}$ \\
\hline Analfabetismo & $\begin{array}{l}0,00337 * * * \\
(0,000459)\end{array}$ & $\begin{array}{l}0,00143 * * * \\
(0,000261)\end{array}$ & $\begin{array}{l}-1,33 \mathrm{e}-05 \\
(8,12 \mathrm{e}-05)\end{array}$ & $\begin{array}{l}0,000639 * * * \\
(0,000167)\end{array}$ & $\begin{array}{l}-6,86 \mathrm{e}-05^{*} \\
(3,70 \mathrm{e}-05)\end{array}$ & $\begin{array}{l}0,000526^{* * *} \\
(0,000185)\end{array}$ \\
\hline Pobreza & $\begin{array}{l}0,000328^{*} \\
(0,000177)\end{array}$ & $\begin{array}{l}0,000359 * * * \\
(0,000106)\end{array}$ & $\begin{array}{l}-0,000119 \text { *** } \\
(2,95 \mathrm{e}-05)\end{array}$ & $\begin{array}{l}7,61 \mathrm{e}-05 \\
(5,79 \mathrm{e}-05)\end{array}$ & $\begin{array}{l}3,64 \mathrm{e}-05 * * \\
(1,76 \mathrm{e}-05)\end{array}$ & $\begin{array}{l}3,80 \mathrm{e}-05 \\
(6,98 \mathrm{e}-05)\end{array}$ \\
\hline Pop & $\begin{array}{l}-9,73 \mathrm{e}-08 \\
(8,35 \mathrm{e}-08)\end{array}$ & $\begin{array}{l}-6,68 \mathrm{e}-09 \\
(1,84 \mathrm{e}-08)\end{array}$ & $\begin{array}{l}-6,29 \mathrm{e}-08 * * * \\
(1,52 \mathrm{e}-08)\end{array}$ & $\begin{array}{l}1,06 \mathrm{e}-08 \\
(5,30 \mathrm{e}-08)\end{array}$ & $\begin{array}{l}2,01 \mathrm{e}-08 * * * \\
(6,21 \mathrm{e}-09)\end{array}$ & $\begin{array}{l}1,60 \mathrm{e}-08 \\
(3,78 \mathrm{e}-08)\end{array}$ \\
\hline Ano & $\begin{array}{l}0,00441 * * * \\
(0,000366)\end{array}$ & $\begin{array}{l}0,000919 * * * \\
(0,000192)\end{array}$ & $\begin{array}{l}0,000530 * * * \\
(5,54 \mathrm{e}-05)\end{array}$ & $\begin{array}{l}0,000881 * * * \\
(0,000114)\end{array}$ & $\begin{array}{l}-0,000166^{* * *} \\
(3,40 \mathrm{e}-05)\end{array}$ & $\begin{array}{l}0,000710^{* * *} \\
(0,000183)\end{array}$ \\
\hline Constante & $\begin{array}{l}-8,816^{* * * *} \\
(0,699)\end{array}$ & $\begin{array}{l}-1,805^{* * * *} \\
(0,374)\end{array}$ & $\begin{array}{l}-1,088 * * * \\
(0,108)\end{array}$ & $\begin{array}{l}-1,741 * * * \\
(0,219)\end{array}$ & $\begin{array}{l}0,329 * * * \\
(0,0668)\end{array}$ & $\begin{array}{l}-1,425 * * * \\
(0,340)\end{array}$ \\
\hline $\begin{array}{l}\text { Observações } \\
\text { R-squared } \\
\text { Municípios }\end{array}$ & $\begin{array}{l}50,876 \\
0,045 \\
5,431\end{array}$ & $\begin{array}{l}50,876 \\
0,020 \\
5,431\end{array}$ & $\begin{array}{l}50,876 \\
0,038 \\
5,431\end{array}$ & $\begin{array}{l}50,876 \\
0,010 \\
5,431\end{array}$ & $\begin{array}{l}50,876 \\
0,011 \\
5,431\end{array}$ & $\begin{array}{l}50,876 \\
0,018 \\
5,431\end{array}$ \\
\hline
\end{tabular}

Nota: Elaborado pela autora. Erro padrão entre parênteses $* * * \mathrm{p}<0.01, * * \mathrm{p}<0.05,{ }^{*} \mathrm{p}<0.1$.

Outro resultado relevante está associado à variável ideologia, em que quanto mais à direita se encontra a posição ideológica do partido que governa o município, menores valores em média são recebidos via transferências voluntárias. Estes resultados corroboram alguns estudos que relacionam gastos públicos elevados a partidos de esquerda enquanto que os de direita seriam mais propensos à disciplina fiscal (TAVARES, 2004). Ademais, esse resultado 
pode ser parcialmente consequência do fato de que em grande parte do período considerado, o presidente da República pertencia a um partido de esquerda.

Prefeitos de primeiro mandato e candidato à reeleição, descritos pela variável G1, apresentam maior recebimento de transferências voluntárias em média em relação a outros possíveis casos. Em oposição, os prefeitos de primeiro mandato e que não são candidatos à reeleição recebem em média menos transferências voluntárias. Esse resultado se relaciona com a pesquisa apresentada no capítulo anterior e sugere um menor esforço no sentido de conseguir recursos adicionais da União quando o prefeito não se vê perspectiva de reeleição.

\subsection{Conclusão}

Este capítulo fez uma análise sobre a concentração dos votos dos partidos políticos para as eleições do Legislativo federal por meio do índice de Quociente Locacional (QL). Notou-se que para as eleições de 2006 e 2010, as áreas de influência para os quatro partidos com os maiores índices (PT, PMDB, PSDB e PP) apresentaram pouca modificação. Em média, os partidos PMDB e PP aumentaram suas áreas de influência política e os partidos PSDB e PT diminuíram seu poder em algumas localidades. A partir do cálculo do indicador QL, construiuse uma variável de identidade partidária entre o Poder Legislativo Federal e o Poder Executivo Municipal, a qual é a principal variável de interesse nos testes empíricos.

O principal resultado e, também, a contribuição original da pesquisa, é a evidência empírica de que as transferências voluntárias são fortemente direcionadas aos municípios que possuem identidade partidária com os partidos com influência política na região. Os resultados reforçam a tese de que os partidos políticos desempenham um importante papel no direcionamento dessas transferências e, além disso, evidenciam o poder conferido aos parlamentares na determinação das políticas públicas subnacionais.

No entanto, ainda que tenhamos identificado o papel significativo do Legislativo no direcionamento dos convênios com os municípios, notou-se que o Executivo nacional ainda exerce papel prevalente sobre esse direcionamento.

Outro resultado interessante, e que se relaciona com o ensaio da pesquisa anterior, sugere que prefeitos de primeiro mandato e com perspectivas de reeleição tendem a receber maiores aportes de convênios públicos ao compararmos com prefeitos de primeiro mandato sem essa perspectiva e com prefeitos de segundo mandato, e sugere um menor esforço no sentido de conseguir recursos adicionais da União quando o prefeito não vê perspectiva de reeleição. 
Enfim, os testes estatísticos apresentados podem contribuir para um melhor entendimento da execução das transferências voluntárias no Brasil, consideradas como recursos clientelistas e distributivos, muitas vezes com impactos negativos política e economicamente.

Este artigo é uma primeira tentativa de entender o efeito da identidade partidária entre o Poder Legislativo federal e o Poder Executivo local nas transferências de rendas voluntárias da União para os municípios. O estudo poderia ser ampliado em diversos aspectos para aprofundar a compreensão dos aspectos políticos na distribuição desse tipo de recurso. Inicialmente poderse-ia analisar separadamente as transferências voluntárias efetivamente emendadas pelos parlamentares e, dessa forma, tentar entender o efeito da identidade partidária com os parlamentares que possuem poder político na região, individualmente. Em segundo lugar, poder-se-ia incluir variáveis para os senadores federais e, além disso, incluir no estudo as transferências voluntárias de origem estadual para os municípios. Essas extensões são deixadas como sugestão para pesquisas futuras. 


\section{ANEXO B - Testes para a metodologia de dados em painel}

Tabela B.1 - Resultado dos testes de Chow e testes de Hausman

\begin{tabular}{llcccc}
\hline & & \multicolumn{2}{c}{ Chow } & \multicolumn{2}{c}{ Hausman } \\
\cline { 3 - 6 } & & $\mathrm{F}(5430,45422)$ & Prob $>\mathrm{F}$ & $\chi^{2}$ & Prob $>\chi^{2}$ \\
\hline Teste 1 & Totais & 2,16 & 0,0000 & 1379,61 & 0,0000 \\
Teste 2 & Saúde & 1,39 & 0,0000 & 367,60 & 0,0000 \\
Teste 3 & MEC & 0,89 & 1,0000 & 391,55 & 0,0000 \\
Teste 4 & MDS & 1,47 & 0,0000 & 918,54 & 0,0000 \\
Teste 5 & Cidades & 1,77 & 0,0000 & 400,12 & 0,0000 \\
Teste 6 & Integração Social & 1,73 & 0,0000 & 232,10 & 0,0000 \\
Teste 7 & Turismo & 1,93 & 0,0000 & 137,65 & 0,0000 \\
\hline
\end{tabular}

Fonte: Elaborado pela autora.

Tabela B.2 - Resultado dos testes de autocorrelação e do teste de heterocedasticidade em grupo

\begin{tabular}{llcccc}
\hline & & \multicolumn{2}{c}{ Teste de Woldridge } & \multicolumn{2}{c}{ Teste de Wald } \\
\cline { 3 - 6 } & & $\mathrm{F}(1,5342)$ & Prob $>\mathrm{F}$ & $\chi^{2}$ & Prob $>\chi^{2}$ \\
\hline Teste 1 & Totais & 13,818 & 0,0002 & $1,9 \mathrm{e}+08$ & 0,0000 \\
Teste 2 & Saúde & 6,684 & 0,0098 & $3,0 \mathrm{e}+10$ & 0,0000 \\
Teste 3 & MEC & 0,168 & 0,6821 & $2,2 \mathrm{e}+09$ & 0,0000 \\
Teste 4 & MDS & 0,438 & 0,5083 & $2,7 \mathrm{e}+11$ & 0,0000 \\
Teste 5 & Cidades & 2,636 & 0,1045 & $9,9 \mathrm{e}+10$ & 0,0000 \\
Teste 6 & Integração Social & 3,367 & 0,0666 & $6,1 \mathrm{e}+10$ & 0,0000 \\
Teste 7 & Turismo & 6,759 & 0,0094 & $9,9 \mathrm{e}+09$ & 0,0000 \\
\hline
\end{tabular}

Fonte: Elaborado pela autora. 


\section{Conclusões finais}

Os resultados principais desta tese evidenciam a relação entre os fatores políticos e institucionais e as políticas fiscais subnacionais. Analisou-se a relação entre os incentivos inerentes à reeleição frente a sustentabilidade fiscal dos municípios e entre os incentivos motivados pelos alinhamentos partidários frente às transferências de recursos via convênios públicos e contratos de repasses federais.

Um dos resultados encontrados nesta tese indica que municípios em que os prefeitos são de primeiro mandato e que possuem expectativas de reeleição tendem a aumentar as despesas e as receitas primárias municipais em uma proporção de forma que o aumento da despesa foi coberto com o aumento da receita, resultando em um superávit primário. Desse modo, o efeito positivo sobre o resultado primário sugere que prefeitos com expectativas de reeleição apresentam uma política fiscal mais sustentável com a geração de receitas em volume suficiente para cobrir as despesas sem comprometer sua capacidade de administrar a dívida existente. Esse aumento da receita primária também pode ser reforçado pelo resultado encontrado no Ensaio 2, em que se inferiu que prefeitos candidatos à reeleição recebem maiores aportes de transferências voluntárias, muito provavelmente pela sua maior disposição em angariar mais recursos para mostrar ao eleitor que é um bom governante. O que reforça a ideia de que o instituto da reeleição pode ser visto como um fator bastante influente na condução da política fiscal.

Por fim, outro resultado bastante relevante desse trabalho é que as transferências voluntárias intergovernamentais no Brasil são significativamente influenciadas por motivações político-partidárias. Construiu-se uma nova medida para identificar a identidade partidária entre o Poder Executivo local e o Poder Legislativo federal e por meio dela mostrou-se empiricamente a existência de influência política no recebimento desses recursos. Os resultados reforçam a tese de que os partidos políticos desempenham um importante papel no direcionamento dessas transferências e, além disso, evidenciam o poder conferido aos parlamentares na determinação das políticas públicas subnacionais. Tomando como base as discussões teóricas dos dois ensaios, infere-se que o sistema político brasileiro cria incentivos para que os eleitores se preocupem mais com os benefícios locais do que com o desempenho nacional dos seus representantes, o que faz com que a participação dos partidos políticos no âmbito nacional, seja orientada pela busca de benefícios que possam ser utilizados localmente, como uma forma de alcançar maiores retornos eleitorais - no caso, a reeleição. 


\section{Referências}

AlbuQuerque, C.; MEDEIROS, M.; FEIJÓ, P. H. Gestão de Finanças Públicas: Fundamentos e Práticas de Planejamento. Brasília: Editora Gestão Pública. ed. 1, 2008.

ALESINA, A. PEROTTI, R. The Political Economy of Budget Deficts. IMF staff papers, 1995.

ALESINA, A.; TABELLINI, G. Rules and Discretion with Non-coordinated Monetary and Fiscal Policy. Economic Inquiry, v. 25, p. 619-30, 1987.

AMES, B. Electoral Rules, Constituency Pressures, and Pork Barrel: Bases of Voting in Brazilian Congress. The Journal of Politics, v. 57, n. 2, p. 324-343, 1995 b.

AMES, B. Electoral Strategy under Open-List Proportional Representation. American Journal of Political Science, vol. 39, n. 2, p. 406-433, 1995a.

AMES, B. Os entraves à democracia no Brasil. Rio de Janeiro: Fundação Getúlio Vargas, 2003.

AVELINO, G.; BIDERMAN, C.; SILVA, G. P. A Concentração Eleitoral nas Eleições Paulistas: Medidas e Aplicações. Dados (Rio de Janeiro. Impresso), v. 54, p. 319-347, 2011.

BCB. BANCO CENTRAL DO BRASIL.Indicadores econômicos consolidados. < http://www.bcb.gov.br/pec/Indeco/Port/indeco.asp >. Acesso em julho de 2015.

BARBOSA, F. H.; BARBOSA, A. L.; CAVALCANTI, C. E.; SILVA, C. R.; MOTTA, J. R. ROARELLI, M. L. Federalismo Fiscal, Eficiência e Equidade: Uma proposta de reforma tributária. 1998.

BARRO, R. J. The control of politicians: An economic model. Public Choice, v. 14, n. 1, p. 19, 1973.

BASTOS, M. R. A implementação de políticas públicas com agenciamento e múltiplos principais: A análise da difusão do Programa Bolsa Família. 2015. 168 f. Tese (Doutorado em Economia) - Pós-Graduação em Economia, Departamento de Economia, Universidade de Brasília, Brasília.

BENDAVID-VAL, A. Regional and Local Economic Analysis for Practioners. New York: Praeger, 1991. p. 67-76.

BESLEY, T. Principled Agents? The Political Economy of Good Government. London School of Economics and Political Science, oct. 2006

BESLEY, T.; CASE A. Does electoral accountability affect economic policy choices?

Evidence from gubernatorial term limits. Quarterly Journal of Economics, v. 3, p. 769-798, 1995. 
BIDERMAN, C., AVARTE, P. R. Economia do Setor Público no Brasil. Rio de Janeiro: Elsevier, 2004.

BRADY D. W. Globalization and Political Instability. The American Interest, v. 11, n. 6, mar. 2016.

BRAMBOR, T.; CENEVIVA, R. Reeleição e continuísmo nos municípios brasileiros. Novos Estudos - CEBRAP, São Paulo, n. 93, p. 09-21, jul. 2012.

BRASIL. Constituição da República Federativa Brasil. Brasília: Senado, 1988.

BRASIL. Lei de Responsabilidade Fiscal. Lei complementar n. ${ }^{\circ} 101$ de 4 de maio de 2000. Estabelece normas de finanças públicas voltadas para a responsabilidade na gestão fiscal e dá outras providências. Diário Oficial \{da\} República Federativa do Brasil. Brasília, DF, 4 de mai. de 2000.

BRASIL. Emenda Constitucional no 86, de 17 de março de 2015. Altera os arts. 165, 166 e 198 da Constituição Federal, para tornar obrigatória a execução da programação orçamentária que especifica. Diário Oficial \{da\} República Federativa do Brasil. Brasília, DF, 17 de mar. de 2015.

BUGARIN, M.; MARCINIUK, F. L. Partisan Transfer in a Fiscal Federation: Evidence from a new Brazilian Database. Working Paper of Economics and Politics Research Group, 2016.

CARDOSO, F. H. A Arte da Política - A História Que Vivi. Cidade de publicação: Rio de Janeiro. Civilização Brasileira. 2006.

CARVALHO, N. R. Geografia política das eleições congressuais: a dinâmica de representação das áreas urbanas e metropolitanas no Brasil. Cadernos Metrópole, São Paulo, v. 11, n. 22, p. 367-384, jul./dez. 2009.

CAVALCANTE, P. Vale a Pena ser um bom prefeito? Comportamento eleitoral e reeleição no Brasil. Opinião Pública, Campinas, vol. 21, n. 1, p. 87-104, 2015.

COSSIO, F. A. B. O comportamento fiscal dos estados brasileiros e seus determinantes políticos. Economia, v. 2, n. 1, p. 207-258, 2001.

COX, G. W.; MCCUBBINS, M. D. Electoral politics as a redistributive game. The Journal of Politics, v 48, p 370-389. 1986.

DATAFOLHA. Avaliação da presidente Dilma Rousseff Intenção de voto para presidente. Jun. 2015 . Disponível em:

<http://media.folha.uol.com.br/datafolha/2015/06/22/avaliacao-dilma-intencao-de-votov2.pdf>. Acesso em:10 set. 2016.

DIXIT, A.; LONDRENGAN, J. Redistributive Politics and Economic Efficiency. The American Political Science Review, v. 89, n. 4, p 856-866, dez. 1996. 
FEREJOHN, J. Incumbent performance and electoral control. Public Choice, v. 50, n. 1-3, 1986.

FERRAZ, C.; FINAN, F. Electoral accountability and corruption in local governments: evidence from audit reports, American Economic Review, v. 101, n. 4, p. 1274-1311, 2010.

FERREIRA, I. F. S.; BUGARIN, M. S. Transferências voluntárias no federalismo fiscal brasileiro: efeito do ciclo fiscal de meio de mandato sobre as reeleições municipais. In: ESAF (Org.): Finanças Públicas: IX Prêmio Tesouro Nacional, 2007. p. 221-278.

FERREIRA, I. F.S.; BUGARIN, M. S. Transferências Voluntárias no Federalismo Fiscal Brasileiro: Efeito do Ciclo Fiscal de Meio de Mandato sobre as Eleições Municipais. In: ESAF (org.): Finanças Públicas: IX Prêmio Tesouro Nacional, 2005. vol. IX, p. 221-278.

FIGUEIREDO, A. C., LIMONGI, F. Incentivos eleitorais, partidos políticos e política orçamentária. Dados Revista de Ciências Sociais, Rio de Janeiro, v. 45, n. 2, p. 303-339, 2002.

FIGUEIREDO, A. C., LIMONGI, F. Política orçamentária no presidencialismo de coalizão. Rio de Janeiro: Editora FGV, 2008.

GERIGK, W.; CLEMENTE, A.; TAFFAREL, M. Gestão financeira e orçamentária nos municípios brasileiros de porte médio depois da LRF. Revista Administração de Empresas, v. 9 , n. 10, 2010.

GIUBERT, A. C. Efeitos da Lei de Responsabilidade Fiscal sobre os gastos dos municípios brasileiros. 2005. Dissertação (Mestrado em Teoria Econômica) - Faculdade de Economia, Administração e Contabilidade, Universidade de São Paulo, São Paulo.

GOBETTI, S. Ajuste Fiscal nos Estados: Uma análise do período 1998-2006. Revista de Economia Contemporânea, Rio de Janeiro, v. 14, n. 1, p. 113-140, jan./abr. 2010.

GRIFFIN, J. D. Electoral Competition and Democratic Responsiveness: A Defense of the Marginality Hypothesis. Journal of Politics, v. 68, p. 911-921, 2006.

LINDBECK, A. Stabilization Policy in Open Economies with Endogenous Politicians. American Economic Review, vol. 66, n. 2, p. 1 - 19, may 1976.

MACRAE C. A Political Model of the Business Cycle. Journal of Political Economy, v. 85, n. 2, p. 239-63, 1977.

MAINWARING, S. Politicians, Parties, and Electoral Systems: Brazil in Comparative Perspective. Comparative Politics, v. 24, n. 1, p. 21-43, 1991.

MARTELLO, A. Contas do setor público têm primeiro déficit da história em 2014. G1. Brasília, 2015. Disponível em: < http://g1.globo.com/economia/noticia/2015/01/contas-dosetor-publico-tem-primeiro-deficit-da-historia-em-2014.html>. Acesso em: 31 ago. 2015. 
MENDES, G. Voto vista do ministro Gilmar Mendes, 2015. Disponível em:

<http://www.justicaeleitoral.jus.br/arquivos/voto-vista-do-ministro-gilmar-mendes-na-aime-

761>. Acesso em: 31 ago. 2015.

MENDES, M. Transformações e impasses da estrutura fiscal e tributária de 1988 a 2013.

Textos para discussão 136. Núcleo de Estudos e Pesquisas da Consultoria Legislativa, 2013.

MENDES, M.; MIRANDA, R.B.; COSIO, F.B. Transferências intergovernamentais no Brasil: diagnóstico e proposta de reforma. Consultoria Legislativa do Senado Federal Textos para discussão nº 40. Brasília, 2008.

MENEGUIN, F.B.; BUGARIN, M.S. Reeleição e política fiscal: um estudo dos efeitos da reeleição nos gastos públicos. Revista de Economia Aplicada, v.5, n.3, p. 601-622, 2001.

MENEGUIN, F. B.; BUGARIN, M. S.; CARVALHO, A. X. Y. O que leva um governante à reeleição? Brasília: IPEA, 2005. Textos para discussão n. 1135.

MENEZES, R. T. Impactos da Lei de Responsabilidade Fiscal sobre os Componentes de Despesa dos Municípios Brasileiros. In: Secretaria do Tesouro Nacional (Org.). Finanças Públicas: X Prêmio Tesouro Nacional, 2005.

MENEZES, R. T.; SAIANI, C. C. S.; ZOGHBI, A. C. P. Demanda Mediana por Serviços Públicos e Reeleição: Evidências Empíricas do Modelo do Eleitor Mediano para os Municípios Brasileiros. In: ENCONTRO NACIONAL DE ECONOMIA, 36., Salvador, 2008. ANPEC: Salvador, 2008.

MUSGRAVE, R. A. Teoria das finanças públicas: um estudo de economia governamental. São Paulo: Atlas, 1976.

NERY, P. F. A reeleição no executivo deve acabar? Brasil, Economia e Governo. 2015. Disponível em: <http://www.brasil-economia-governo.org.br/2013/09/02/a-reeleicao-noexecutivo-deve-acabar/>. Acesso em: 21 mai. 2016.

NICOLAU, J. O Sistema Eleitoral de Lista Aberta no Brasil. Dados Revista de Ciências Sociais, Rio de Janeiro, v. 49, n. 4, p. 689-720, 2006.

NORDHAUS, W. The Political Business Cycle. The Review of Economic Studies, v. 42, n. 2, p. 169-190, 1975.

NOVAES, L.; MATTOS, E. O efeito da intenção de reeleição sobre gastos em saúde: uma análise com base no modelo de reputação política. Revista de Economia Política, São Paulo, v. 30, n.1, 2010.

PELTZMAN, S. Voters as fiscal conservatives. Quartely Journal of Economics, n. 2, p. 327-361, 1992.

PEREIRA, C.; MUELLER, B. Comportamento Estratégico em Presidencialismo de Coalizão: as relações entre executivo e legislativo na elaboração do orçamento brasileiro. Revista de Ciências Sociais, Rio de Janeiro, v. 45, n. 2, p. 265-301, 2002. 
PEREIRA, C.; MUELLER, B. Partidos fracos na arena eleitoral e partidos fortes na arena legislativa: a conexão eleitoral no Brasil. Dados Revista de Ciências Sociais, Rio de Janeiro, v. 46, n. 4, p. 734-771, 2003.

PEREIRA, C.; RENNÓ, L. O que é que o reeleito tem? Dinâmicas político-institucionais locais e nacionais nas eleições de 1998 para a Câmara dos Deputados. Dados Revista de Ciências Sociais, vol. 44, n. 2, p. 133-172, 2001.

POWER, T.; ZUCCO Jr., C. Estimating Ideology of Brazilian Legislative Parties, 1990-2005: A Research Communication. Latin American Research Review, v. 44, n. 1, p. 219-246, 2009.

RAE, D. Comment on Wildgen's "The measurement of hyperfractionalization".

Comparative Political Studies, v. 4, p. 244-245, jul. 1971.

ROGOFF, K.; SILBERT, A. Equilibrium political business cycle. Review of Economic Studies, v. 55, n. 1, p. 1-16, 1988.

ROGOFF, K. Equilibrium Political Budget Cycles. The American Economic Review, v. 80, n. 1, p. 21-36, 1990.

ROUBINI, N.; SACHS, J. D. Political and economic determinants of budget deficits in the industrial democracies. European Economic Review, North Holland, v. 33, p. 903-938, 1989.

SAKURAI, S. N. Superávit e déficit fiscal dos municípios brasileiros: uma aplicação do modelo de viés de seleção em painel. Nova Economia, Belo Horizonte, v. 24, n. 3, p. 517 $540,2014$.

SAMUELS, D. Pork Barreling is not credit claiming or advertising: Campaign finance and the source of personal vote in Brazil. The Journal of Politics, v. 64, n. 3, p. 845-63, 2002.

SCHNEIDER, R.; ATHIAS, D.; BUGARIN, M. Eletronic voting and Social Spending: The impact of enfranchisement on municipal public spending in Brazil. Working Paper of Economics and Politics Research Group, 2016.

SILVA, G. P. Verificação Empírica sobre o Conceito de Dominância Política: o caso Paulista. In: ENCONTRO DA ABCP, 7., 2010, Recife. Organizador do encontro: Recife, 2010.

SILVA, G. P.; BIDERMAN, C.; AVELINO, G . Indicadores para avaliar o Comportamento Parlamentar como Resultante de Eleições. In: ENCONTRO ANUAL DA ANPOCS, 33., Caxambu, 2009. Organizador do encontro: Caxambu, 2009.

SILVA, G. P; DAVIDIAN, A. Identification of Areas of Vote Concentration: Evidences from Brazil. Brazilian Political Science Review, v. 7, n. 2, p. 141 - 155, 2013. Notas de Pesquisa.

SODRÉ, A. C. A.; ALVES, M. F. C. Relação entre emendas parlamentares e corrupção municipal no Brasil: estudo dos relatórios do programa de fiscalização da Controladoria-Geral da União. Revista de Administração Contemporânea, Curitiba, v.14, n.3, p. 414-433, mai./jun. 2010. 
SPENCE, M.; BRADY, D. W. Economics in a Time of Political Instability. Project Syndicate. The word's opinion page. Prague/New York, mar. 2016.

STONECASH, J. M. Reassessing the Incumbency Effect. New York: Cambridge University Press, 2008.

TAAGEPERA, R. Inequality, Concentration and Imbalance. Political Methodology, v. 6, p. 275-91, 1979.

TAVARES, J. Does right or left matter? Cabinets, ideology and fiscal adjustments. Journal of Public Economics, v. 88, p. 2447-2468, 2004.

WEO. World Economic Outlook. World Economic and Financial Surveys. International Monetary Fund (FMI), apr. 2016.

WERNECK, R. L. F. Federalismo fiscal e a política de estabilização no Brasil. Revista Brasileira de Economia, n. 49, v. 2, p. 375-390, 1995.

WOOLDRIDGE, J. Econometric Analysis of Cross Section and Panel Data. Massachusetts London: The MIT Press Cambridge, 2002.

Introductory Econometrics: A Modern Approach. Fourth edition. SouthWestern. Thompson, 2006. 